\title{
Self-assembly of functionalized lipophilic guanosines into cation-free stacked G-quartets
}

Marilena Campitiello, ${ }^{\mathrm{a}}$ Alessio Cremonini, ${ }^{\mathrm{a}}$ Marco A. Squillaci, ${ }^{\mathrm{b}}$ Silvia Pieraccini, ${ }^{\mathrm{a}}$ Artur Ciesielski, ${ }^{\mathrm{b}}$ Paolo Samorì, ${ }^{* \mathrm{~b}}$ Stefano Masiero *a

a Alma Mater Studiorum - Università di Bologna, Dipartimento di Chimica "Giacomo Ciamician", Via S. Giacomo 11, 40126 Bologna, Italy. E-mail: stefano.masiero@unibo.it

${ }^{\mathrm{b}}$ Université de Strasbourg, CNRS, ISIS, 8 allée Gaspard Monge, 67000 Strasbourg, France.

$\begin{array}{ll}\text { Synthetic schemes 1-4 S2 } & \text { S }\end{array}$

$\begin{array}{ll}\text { Selected CD spectra (Figure S1) } & \text { S4 }\end{array}$

VT ${ }^{1} \mathrm{H}-\mathrm{NMR}$ of compounds 1-8 (Figure S2-S9) S5

$\begin{array}{ll}\text { Table S1 } & \text { S13 }\end{array}$

Selected 1D-NOESY spectra of compounds 1-8 (Figure S10-S16) S14

$\begin{array}{ll}\text { Figure S17 } & \text { S21 }\end{array}$

$\begin{array}{ll}\text { Figure S18 } & \text { S22 }\end{array}$

Spectra of compounds 1-14 $\quad$ S23 
<smiles>Nc1nc2c(ncn2C[C@H]2O[C@H](CO)[C@@H](O)[C@H]2O)c(=O)[nH]1</smiles>

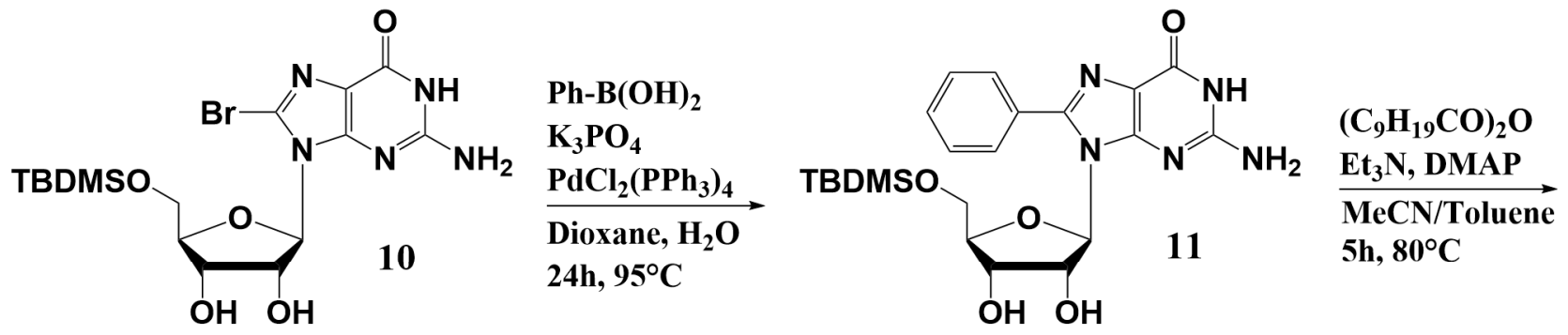

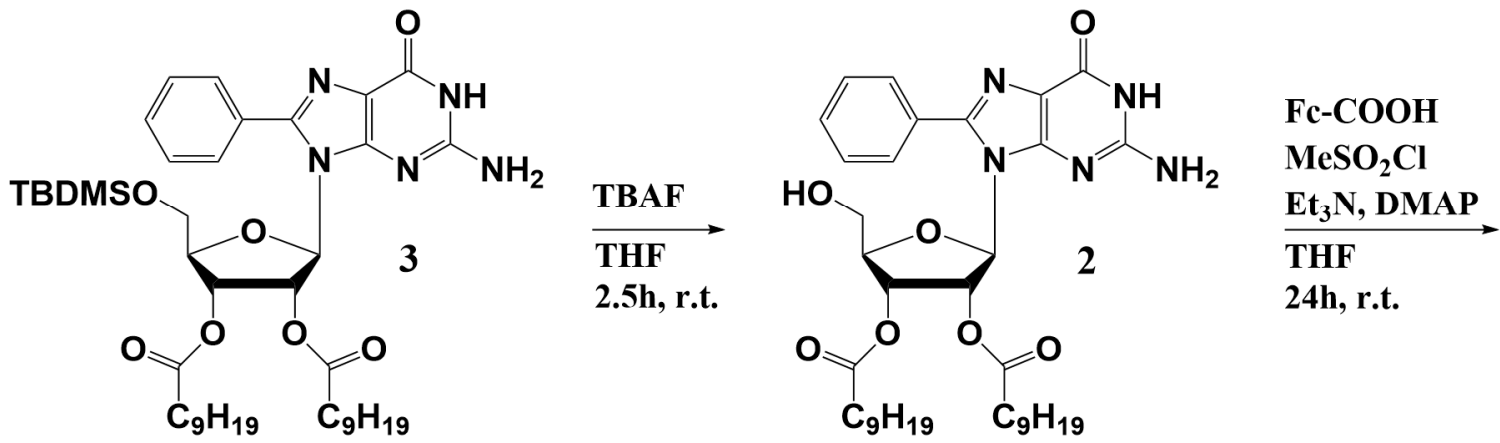

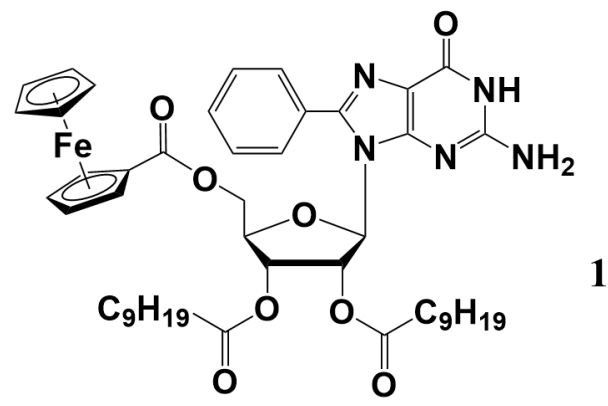

Scheme S1. Synthesis of guanosines 1-3 from commercial guanosine. 


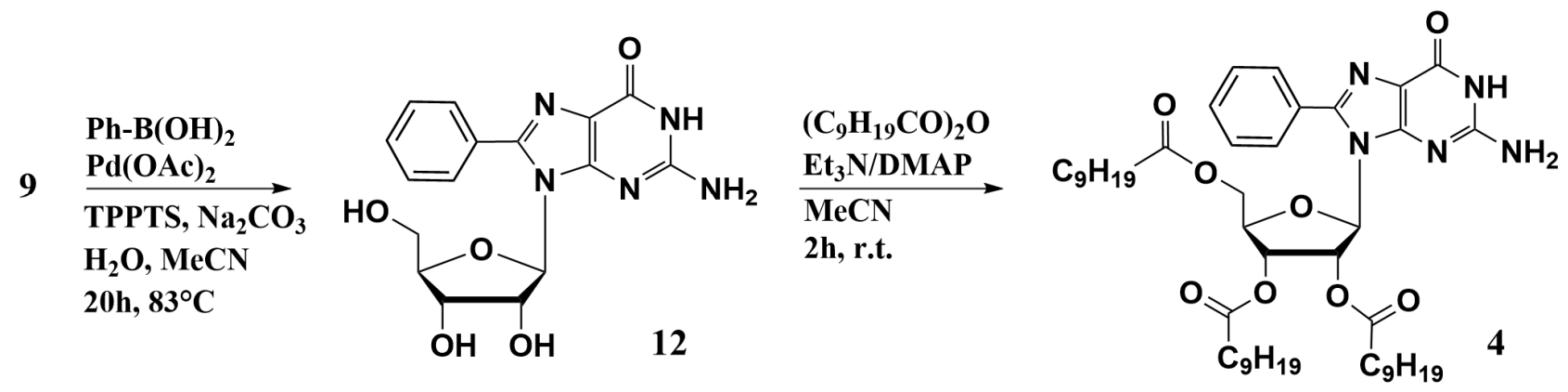

Scheme S2. Synthesis of guanosine 4 (8Ph5C10).

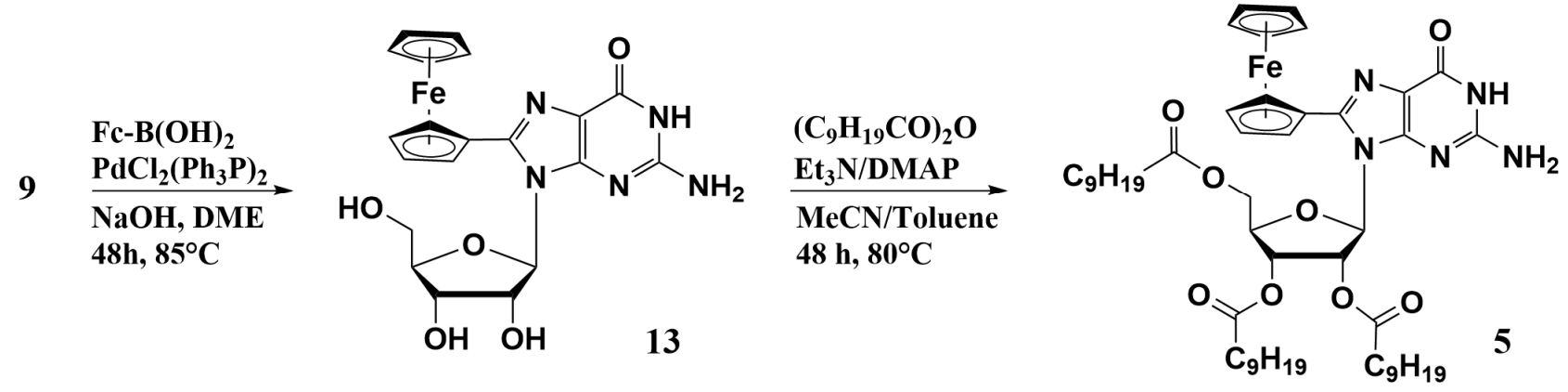

Scheme S3. Synthesis of guanosine 5 (8Fc5C10).
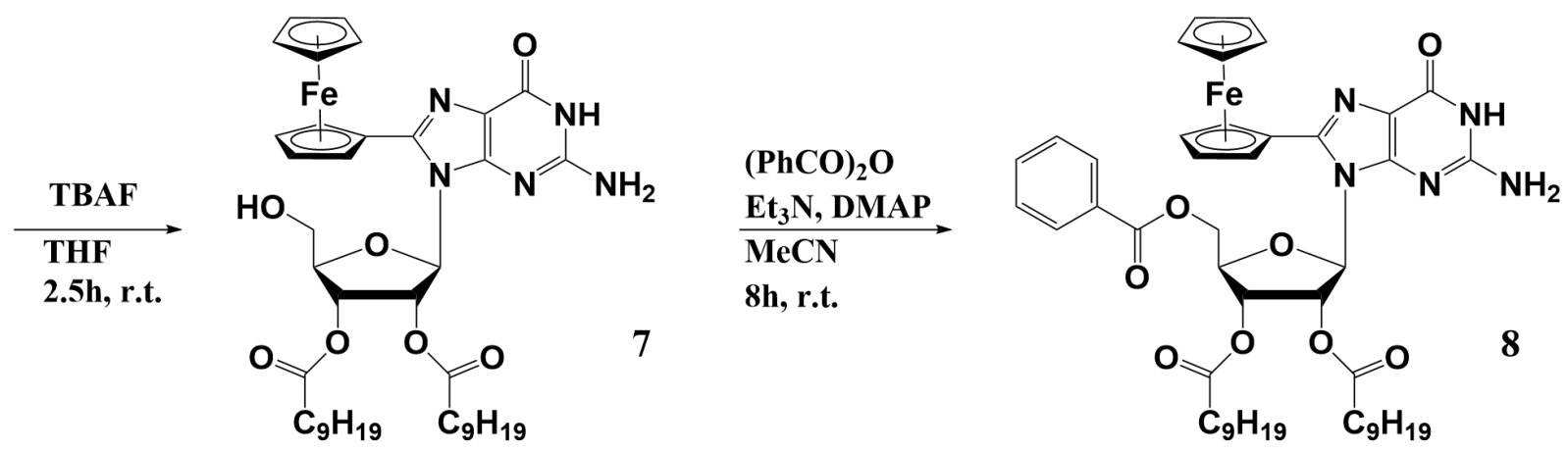

Scheme S4. Synthesis of guanosines 6-8 


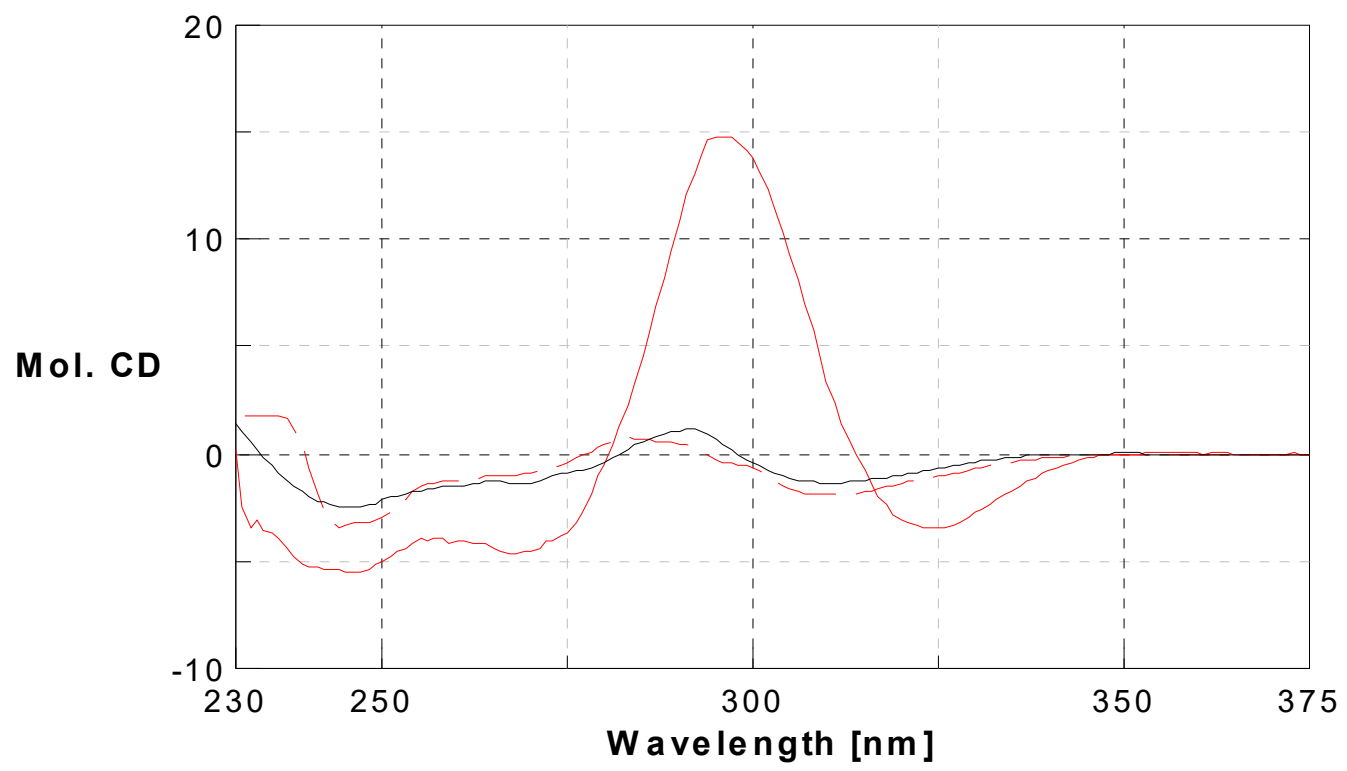

$\mathrm{CD}$ spectra recorded on $10 \mathrm{mM} \mathrm{CH}_{2} \mathrm{Cl}_{2}$ solutions of $\mathbf{8 P h 5 F}$ before (black trace) and after addition of [2.2.2] cryptand (red dotted trace) or excess of KI (red continuous trace). Path length $0.01 \mathrm{~cm}$.

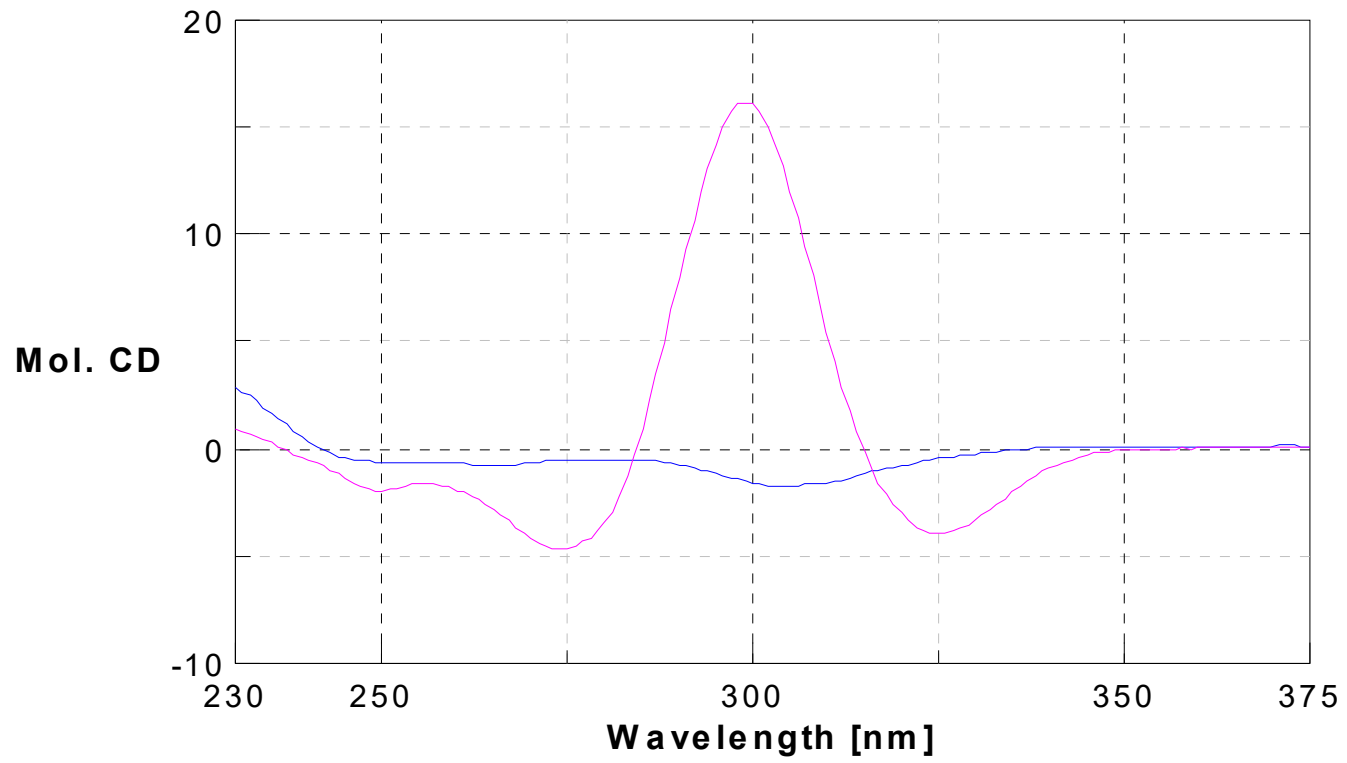

$\mathrm{CD}$ spectra recorded on $10 \mathrm{mM} \mathrm{CH}_{2} \mathrm{Cl}_{2}$ solutions of $\mathbf{8 P h 5 S i}$ before (blue trace) and after addition of $\mathrm{KI}$ (pink trace). Path length $0.01 \mathrm{~cm}$.

Figure S1._Selected CD spectra showing the behaviour of guanosines 1 and $\mathbf{3}$ upon addition of [2.2.2] cryptand or excess KI. 


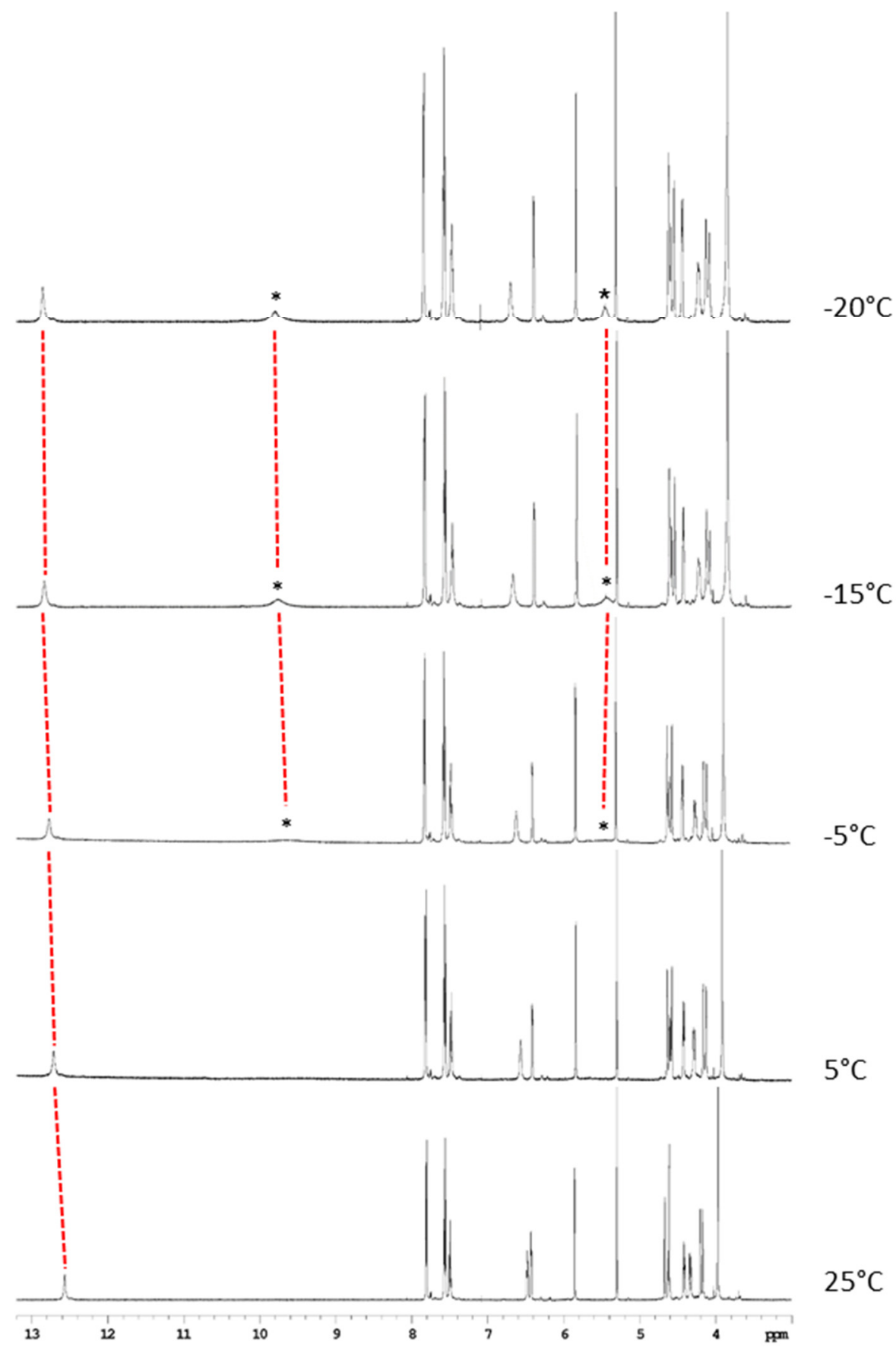

Figure S2._Downfield portion of the $600 \mathrm{MHz}{ }^{1} \mathrm{H}-\mathrm{NMR}$ spectrum of $\mathbf{8 P h 5 F c}(4.3 \mathrm{mM})$ at different temperatures in $\mathrm{CD}_{2} \mathrm{Cl}_{2}$. Amino protons are marked with asterisks. 


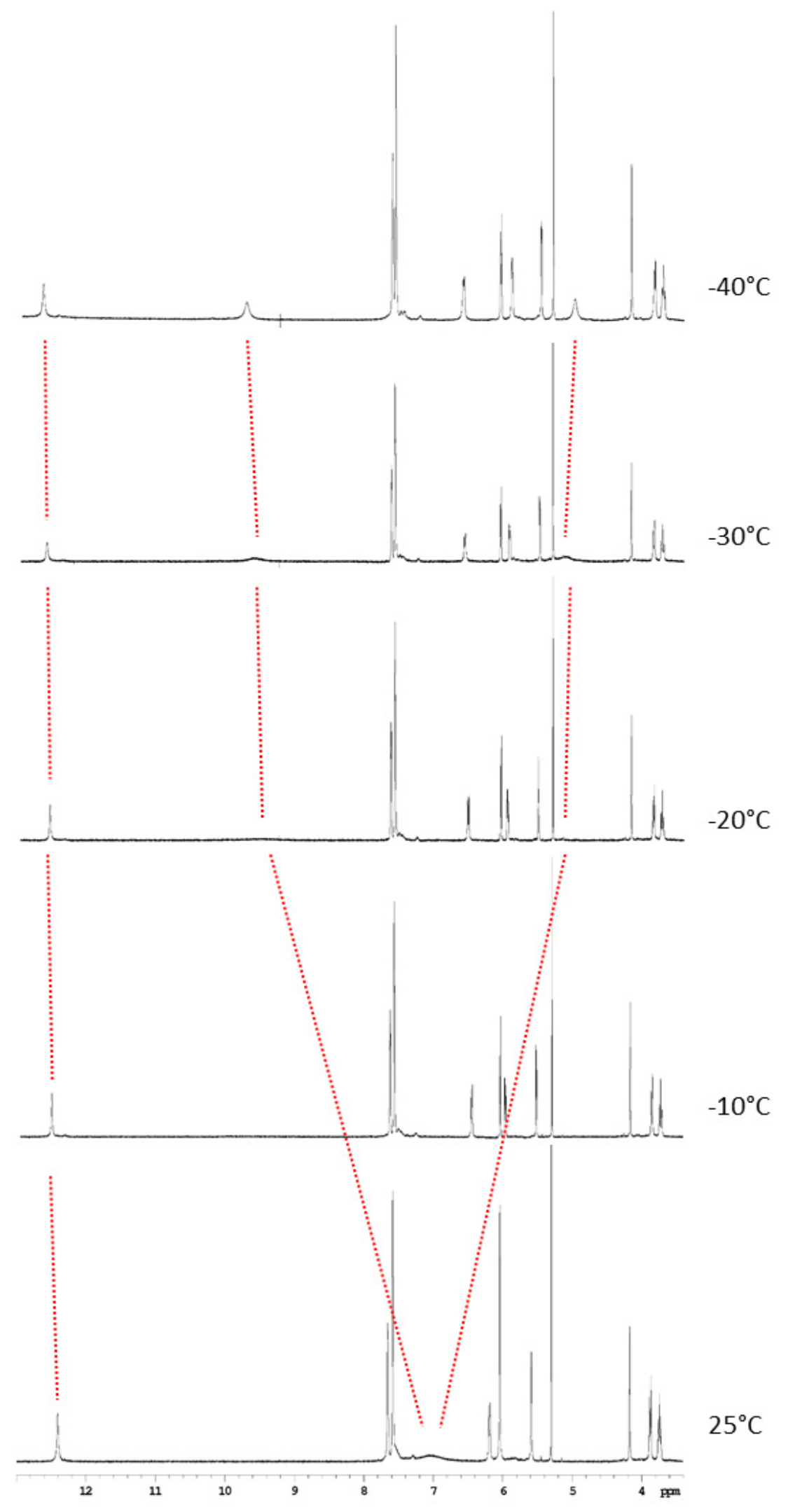

Figure S3. Downfield portion of the $600 \mathrm{MHz}{ }^{1} \mathrm{H}-\mathrm{NMR}$ spectrum of $\mathbf{8 P h 5 O H}(5 \mathrm{mM})$ at different temperatures in $\mathrm{CD}_{2} \mathrm{Cl}_{2}$. 


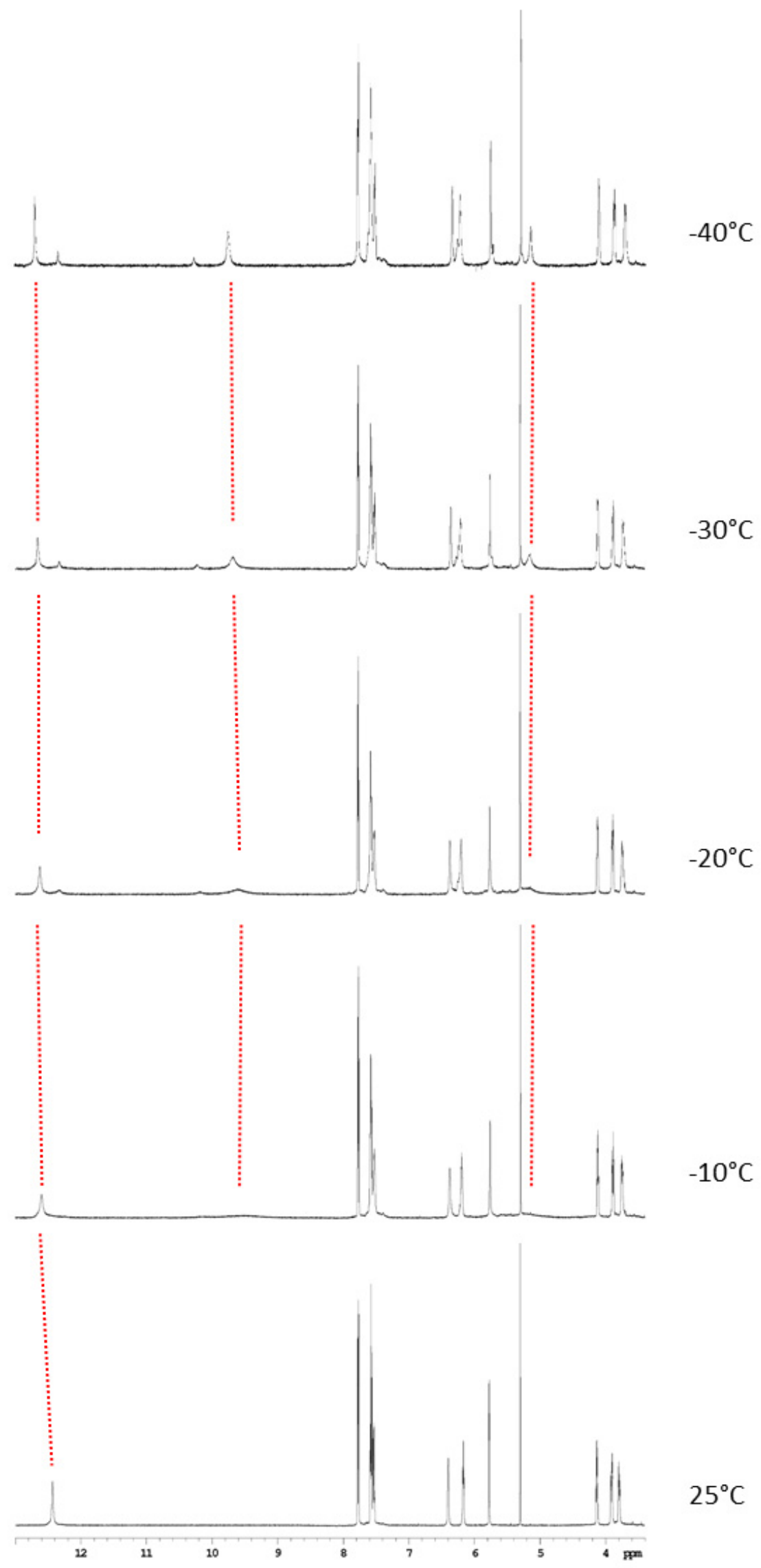

Figure S4. Downfield portion of the $600 \mathrm{MHz}{ }^{1} \mathrm{H}-\mathrm{NMR}$ spectrum of 8Ph5Si $(6 \mathrm{mM})$ at different temperatures in $\mathrm{CD}_{2} \mathrm{Cl}_{2}$. 


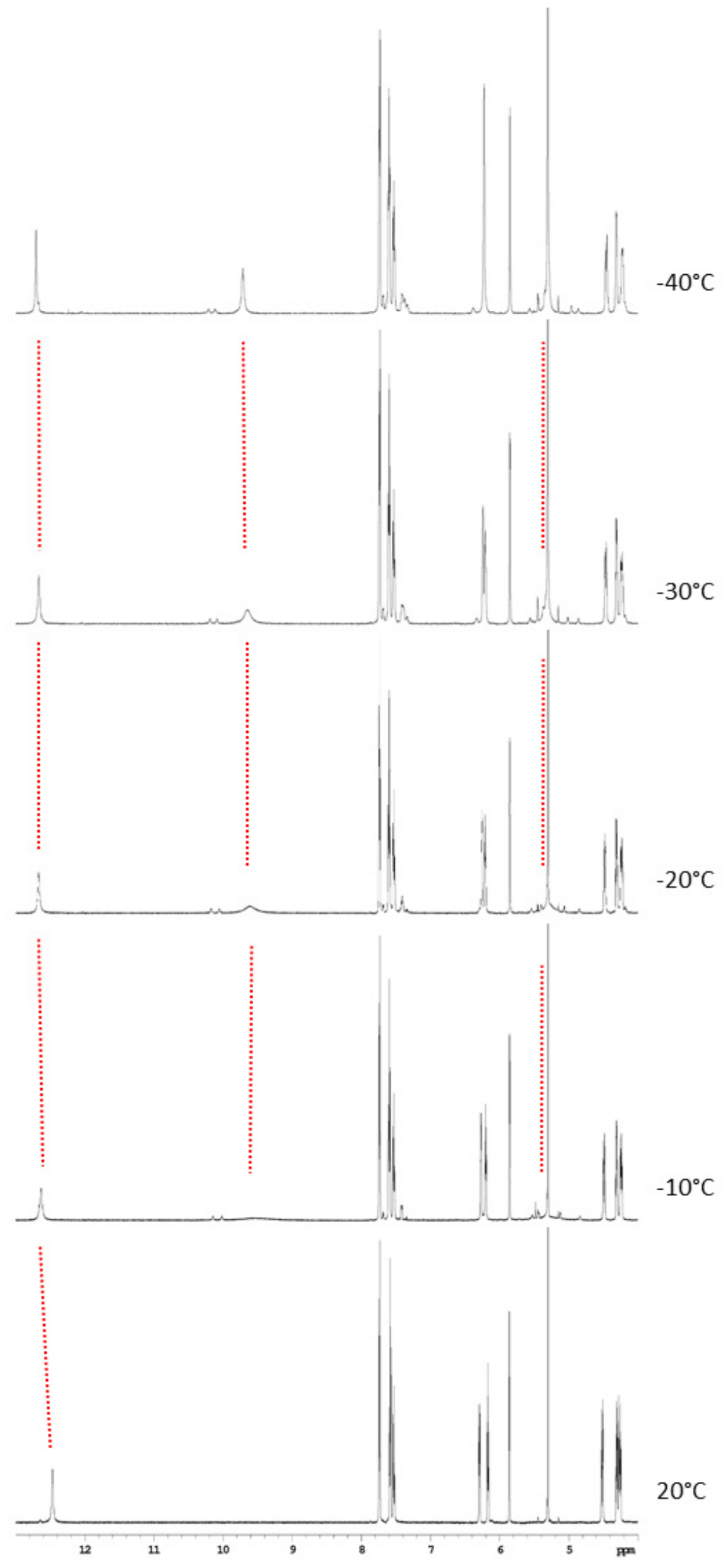

Figure S5. Downfield portion of the $600 \mathrm{MHz}{ }^{1} \mathrm{H}-\mathrm{NMR}$ spectrum of $\mathbf{8 P h 5 C 1 0}(7 \mathrm{mM})$ at different temperatures in $\mathrm{CD}_{2} \mathrm{Cl}_{2}$. 


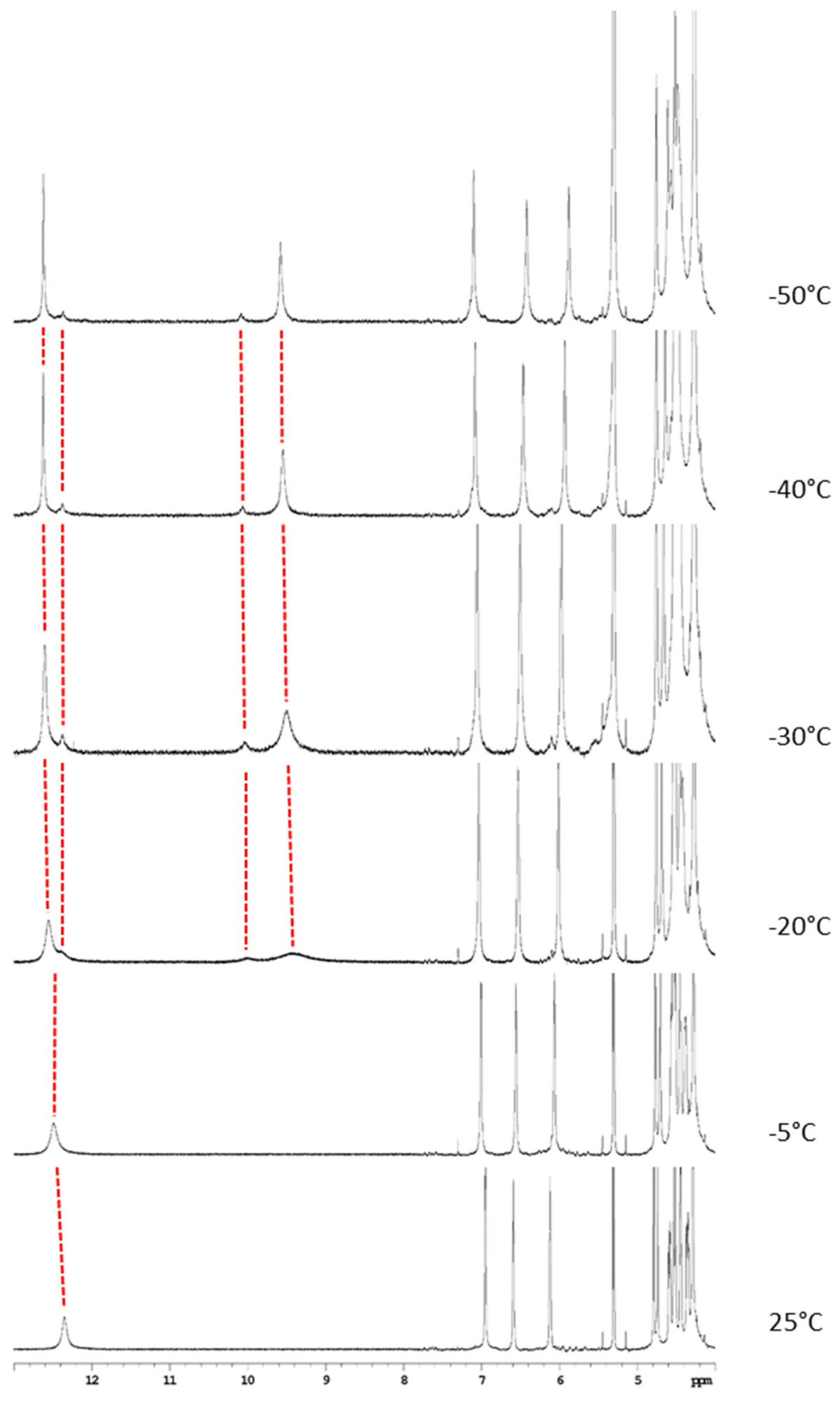

Figure S6. Downfield portion of the $600 \mathrm{MHz}{ }^{1} \mathrm{H}-\mathrm{NMR}$ spectrum of 8 Fc5C10 (4.5 mM) at different temperatures in $\mathrm{CD}_{2} \mathrm{Cl}_{2}$. 

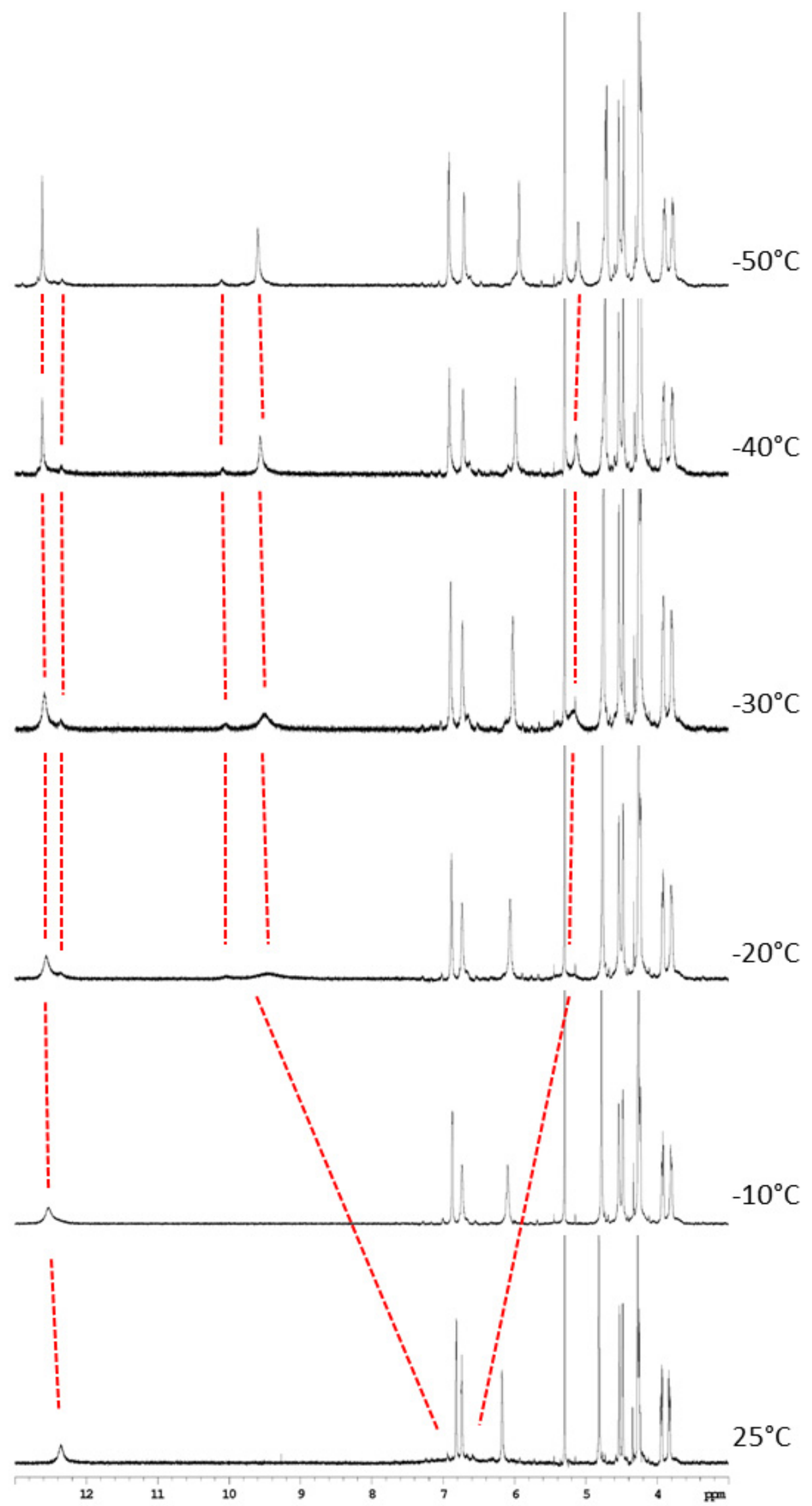

Figure S7. Downfield portion of the $600 \mathrm{MHz}{ }^{1} \mathrm{H}-\mathrm{NMR}$ spectrum of 8Fc5Si $(6 \mathrm{mM})$ at different temperatures in $\mathrm{CD}_{2} \mathrm{Cl}_{2}$. 


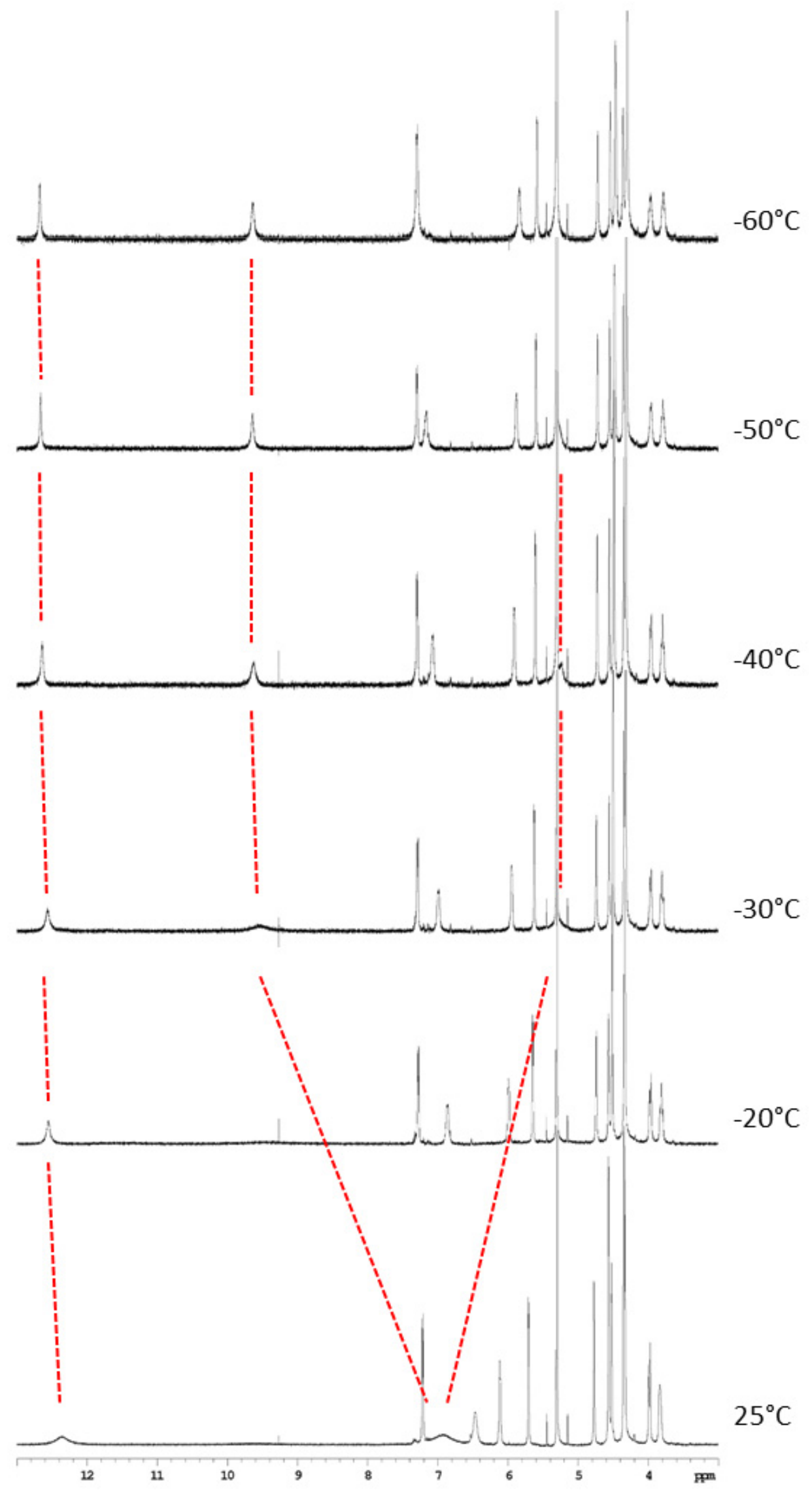

Figure S8. Downfield portion of the $600 \mathrm{MHz}{ }^{1} \mathrm{H}-\mathrm{NMR}$ spectrum of $\mathbf{8 F c 5 O H}(7 \mathrm{mM})$ at different temperatures in $\mathrm{CD}_{2} \mathrm{Cl}_{2}$. 


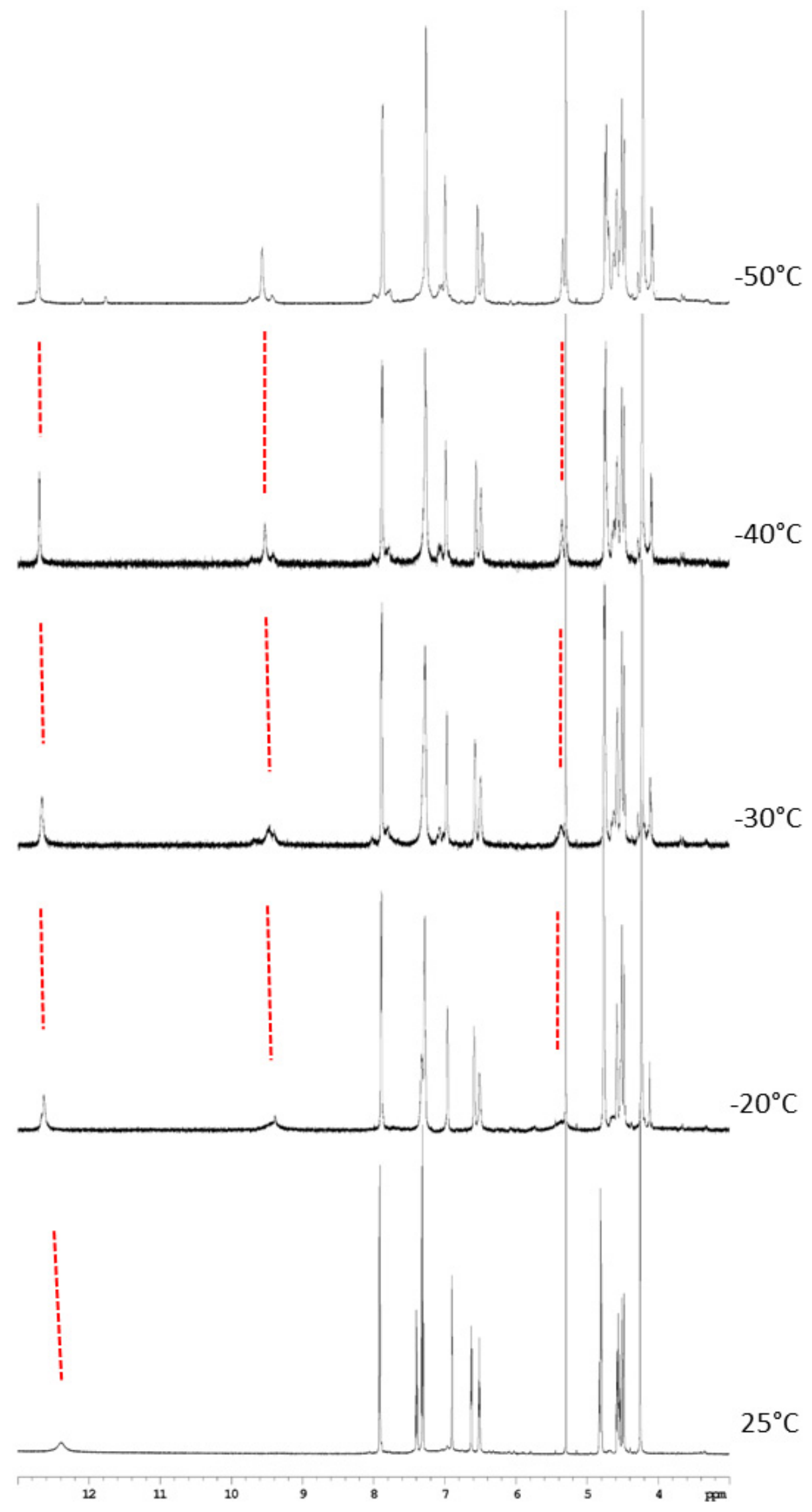

Figure S9. Downfield portion of the $600 \mathrm{MHz}{ }^{1} \mathrm{H}-\mathrm{NMR}$ spectrum of $\mathbf{8 F} \mathbf{5 P h}(4 \mathrm{mM})$ at different temperatures in $\mathrm{CD}_{2} \mathrm{Cl}_{2}$. 
Table S1. Room temp. chemical shifts* for sugar protons.

\begin{tabular}{|c|c|c|c|c|c|c|}
\hline & Compound & solvent & $\delta\left(1^{\prime}\right)$ & $\delta\left(2^{\prime}\right)$ & $\delta\left(3^{\prime}\right)$ & $\delta$ sequence \\
\hline $\mathbf{a}$ & \multirow[t]{2}{*}{ 8Ph5Fc } & dmso & 5.808 & 6.31 & 5.83 & $2^{\prime}>3^{\prime}>1^{\prime}$ \\
\hline & & dem & 5.86 & 6.43 & 6.48 & $3^{\prime}>2^{\prime}>1^{\prime}$ \\
\hline \multirow[t]{2}{*}{$\mathbf{b}$} & \multirow[t]{2}{*}{$8 \mathrm{Ph5OH}$} & dmso & 5.78 & 5.496 & 5.186 & $1^{\prime}>2^{\prime}>3^{\prime}$ \\
\hline & & dem & 6.2 & 6.04 & 5.588 & $1^{\prime}>2^{\prime}>3^{\prime}$ \\
\hline \multirow[t]{2}{*}{ c } & \multirow[t]{2}{*}{ 8Ph5Si } & dmso & 5.75 & 6.36 & 6.17 & $2^{\prime}>3^{\prime}>1^{\prime}$ \\
\hline & & $\mathrm{dcm}$ & 5.75 & 6.26 & 5.63 & $2^{\prime}>1^{\prime}>3^{\prime}$ \\
\hline \multirow[t]{2}{*}{ d } & \multirow[t]{2}{*}{ 8Ph5C10 } & dmso & - & - & - & - \\
\hline & & $\mathrm{dcm}$ & 5.86 & 6.29 & 6.16 & $2^{\prime}>3^{\prime}>1^{\prime}$ \\
\hline \multirow[t]{2}{*}{$\mathbf{i}$} & \multirow[t]{2}{*}{$8 F c 5 C 10$} & dmso & 6.75 & 6.58 & 5.74 & $1^{\prime}>2^{\prime}>3^{\prime}$ \\
\hline & & $\mathrm{dcm}$ & 6.95 & 6.59 & 6.12 & $1^{\prime}>2^{\prime}>3^{\prime}$ \\
\hline \multirow[t]{2}{*}{ e } & \multirow[t]{2}{*}{$8 F c 5 S i$} & dmso & 6.747 & 6.69 & 5.71 & $1^{\prime}>2^{\prime}>3^{\prime}$ \\
\hline & & $\mathrm{dcm}$ & 6.82 & 6.74 & 6.18 & $1^{\prime}>2^{\prime}>3^{\prime}$ \\
\hline \multirow[t]{2}{*}{ f } & \multirow[t]{2}{*}{$8 \mathrm{Fc5OH}$} & dmso & 6.86 & 5.61 & 5.3 & $1^{\prime}>2^{\prime}>3^{\prime}$ \\
\hline & & $\mathrm{dcm}$ & 7.22 & 6.12 & 5.71 & $1^{\prime}>2^{\prime}>3^{\prime}$ \\
\hline \multirow[t]{2}{*}{ g } & \multirow[t]{2}{*}{ 8Fc5Ph } & dmso & 6.77 & 6.63 & 5.99 & $1^{\prime}>2^{\prime}>3^{\prime}$ \\
\hline & & $\mathrm{dcm}$ & 6.9 & 6.63 & 6.51 & $1^{\prime}>2^{\prime}>3^{\prime}$ \\
\hline $\mathbf{h}$ & $\begin{array}{l}\text { 8-Bromo-2,3,5-tri-O-decanoylguanosine } \\
\mathbf{1}\end{array}$ & dmso & 5.84 & 6.02 & 5.68 & $2^{\prime}>1^{\prime}>3^{\prime}$ \\
\hline i & $2,3,5$-tri-O-decanoylguanosine ${ }^{2}$ & dmso & 5.96 & 5.81 & 5.52 & $1^{\prime}>2^{\prime}>3^{\prime}$ \\
\hline 1 & 2,3,5-tri-O-acetylguanosine & dmso $^{3}$ & 6.007 & 5.809 & 5.515 & $1^{\prime}>2^{\prime}>3^{\prime}$ \\
\hline \multirow[t]{2}{*}{$\mathbf{m}$} & \multirow[t]{2}{*}{ 8-Bromoguanosine 9} & dmso $^{4}$ & & 4.89 & & \\
\hline & & dmso & 5.68 & 5.01 & 4.14 & $1^{\prime}>2^{\prime}>3^{\prime}$ \\
\hline \multirow[t]{2}{*}{$\mathbf{n}$} & \multirow[t]{2}{*}{ Guanosine } & $\mathrm{dmso}^{4}$ & & 4.36 & & \\
\hline & & $\mathrm{dmso}^{3}$ & 5.723 & 4.429 & 4.113 & $1^{\prime}>2^{\prime}>3^{\prime}$ \\
\hline
\end{tabular}

* signals are referenced to residual solvent peak.

1. Prepared as described in Giorgi, T.; Lena, S.; Mariani, P.; Cremonini, M. A.; Masiero, S.; Pieraccini, S.; Rabe, J. P.; Samori, P.; Spada, G. P.; Gottarelli, G. J. Am. Chem. Soc. 2003, 125, 14741

2. Prepared as described in Devetak, M.; Masiero, S.; Pieraccini, S.; Spada, G. P.; Copic, M.; Olenik, I. D. Appl. Surf. Sci. 2010, 256, 2038

3. Spectral Database for Organic Compounds (https://sdbs.db.aist.go.jp/sdbs/cgi-

bin/cre_disclaimer.cgi?REQURL=/sdbs/cgibin/cre_index.cgi\&amp;REFURL=http://www.bing.com/search $\% 3 \mathrm{fq}=\mathrm{sp}$ ectra + database + japan $\&$ form $=$ PRASU $1 \&$ src $=I E 11$ TR $\& p c=$ ASTE)

4. L. E. Buerkle, H. A. von Recumab, S. J. Rowan, Chem. Sci., 2012, 3, 564 and references cited therein. 


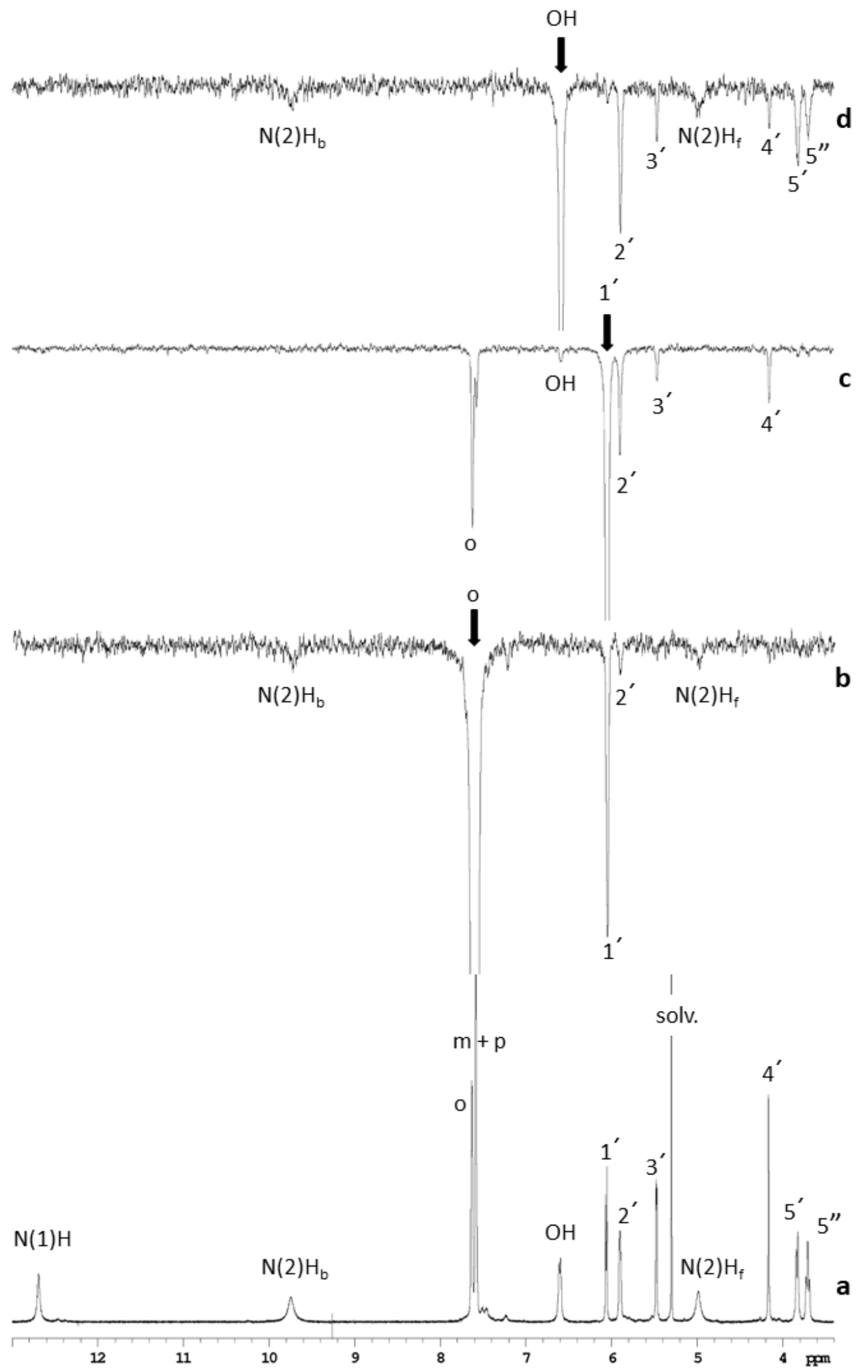

Figure S10. a) Downfield portion of the $600 \mathrm{MHz}{ }^{1} \mathrm{H}-\mathrm{NMR}$ spectrum of $\mathbf{8 P h 5 O H}$ in $\mathrm{CD}_{2} \mathrm{Cl}_{2}(5$ $\mathrm{mM}$ ) and signals assignment (diastereotopic protons were not assigned); b), c), d): selected NOESY-1D spectra of the same sample. Irradiated signals are indicated by an arrow. In each NOE spectrum were used at least 1024 coadded transients, a recycle delay of $1 \mathrm{sec}$, a mixing time of 0.25 sec and a $20-50 \mathrm{~Hz}$ shaped pulse. All spectra were recorded at $-40^{\circ} \mathrm{C}$. 


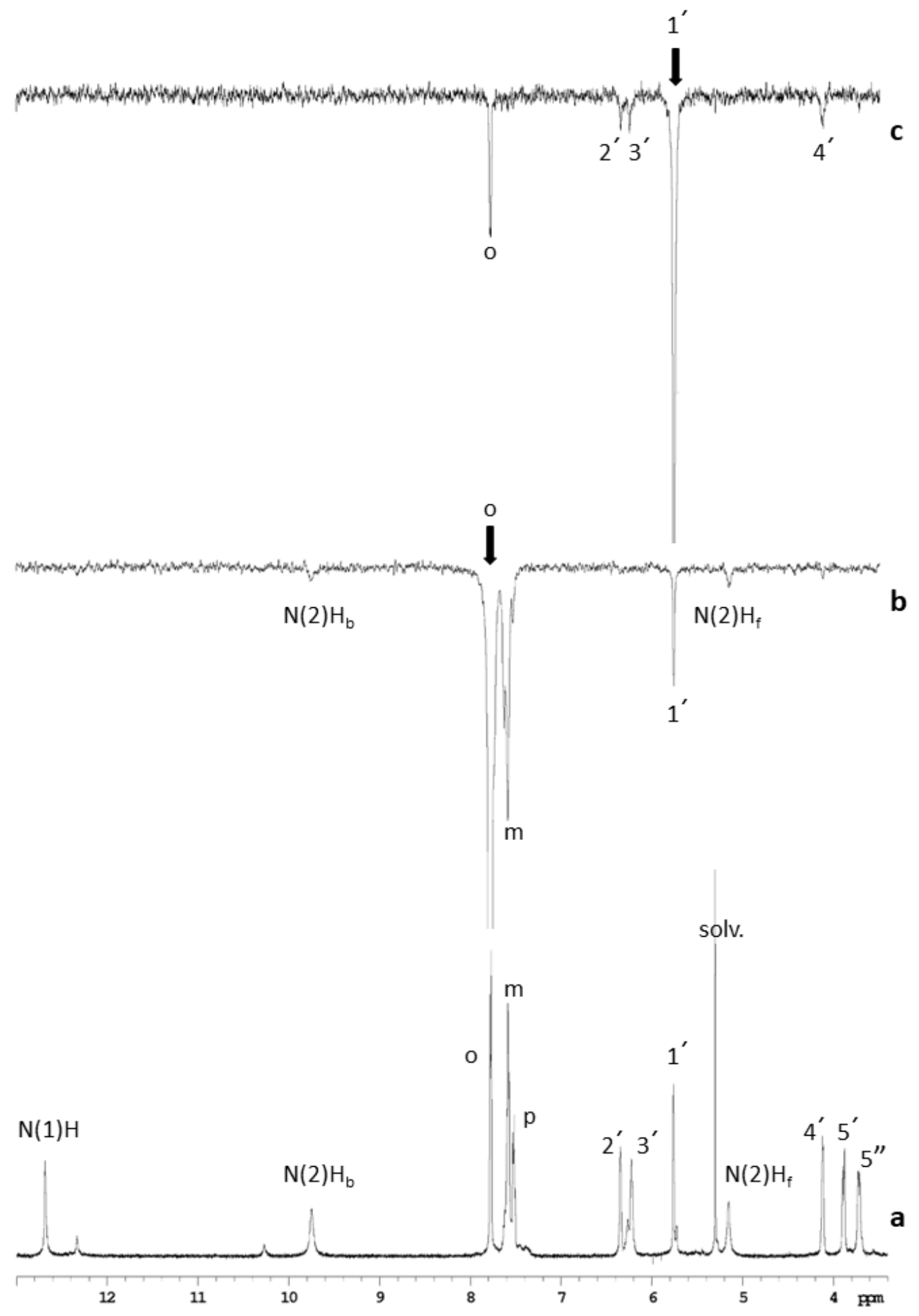

Figure S11. a) Downfield portion of the $600 \mathrm{MHz}{ }^{1} \mathrm{H}-\mathrm{NMR}$ spectrum of $\mathbf{8 P h 5 S i}$ in $\mathrm{CD}_{2} \mathrm{Cl}_{2}(6 \mathrm{mM})$ and signals assignment (diastereotopic protons were not assigned); b), c): selected NOESY-1D spectra of the same sample. Irradiated frequencies are indicated by an arrow. In each NOE spectrum were used at least 512 coadded transients, a recycle delay of $1 \mathrm{sec}$, a mixing time of $0.2 \mathrm{sec}$ and a $20-50 \mathrm{~Hz}$ shaped pulse. All spectra were recorded at $-40^{\circ} \mathrm{C}$. 


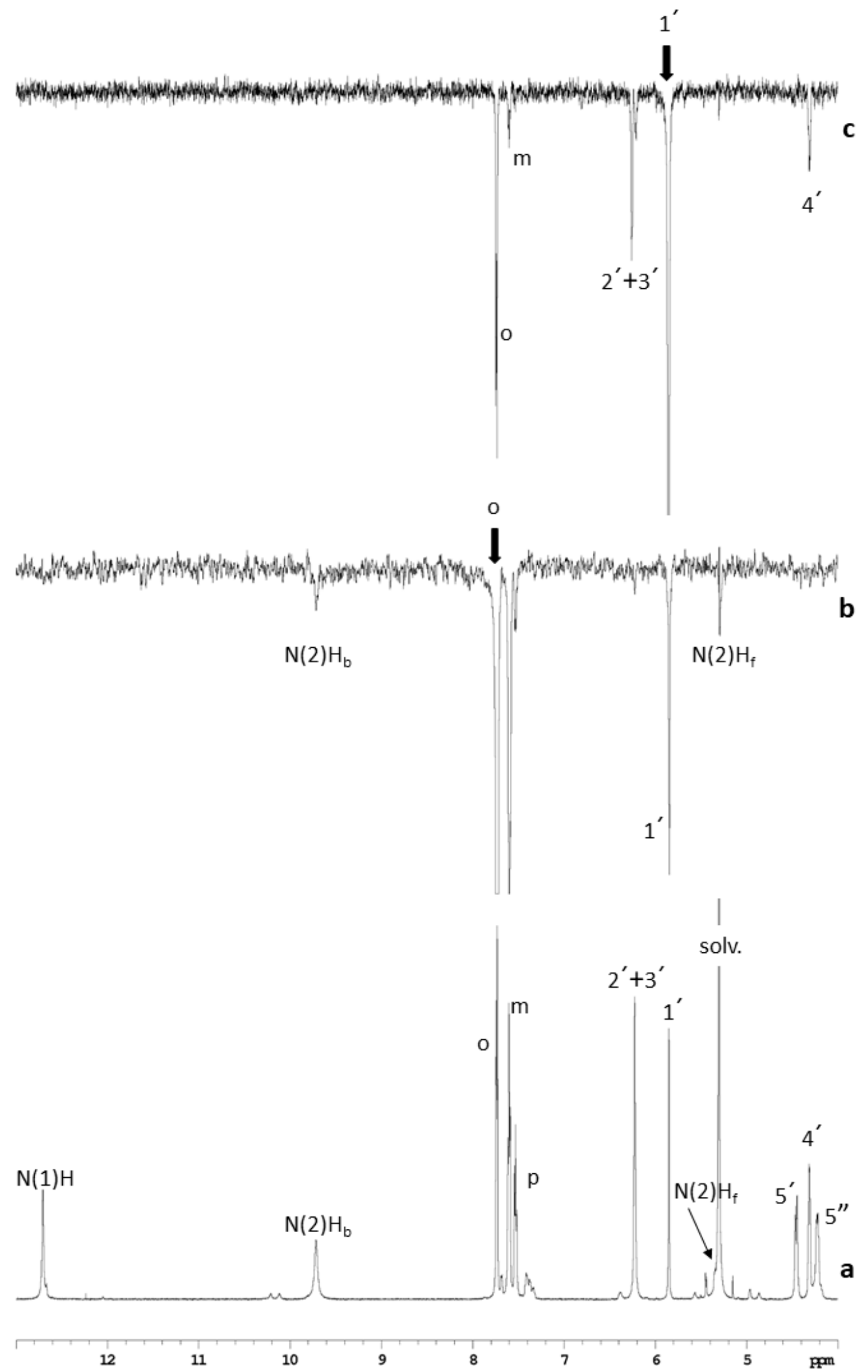

Figure S12. a) Downfield portion of the $600 \mathrm{MHz}{ }^{1} \mathrm{H}-\mathrm{NMR}$ spectrum of $\mathbf{8 P h 5 C 1 0}$ in $\mathrm{CD}_{2} \mathrm{Cl}_{2}(7$ $\mathrm{mM}$ ) and signals assignment (diastereotopic protons were not assigned); b), c): selected NOESY1D spectra of the same sample. Irradiated signals are indicated by an arrow. In each NOE spectrum were used at least 256 coadded transients, a recycle delay of $1 \mathrm{sec}$, a mixing time of $0.4 \mathrm{sec}$ and a $20-50 \mathrm{~Hz}$ shaped pulse. All spectra were recorded at $-40^{\circ} \mathrm{C}$. 

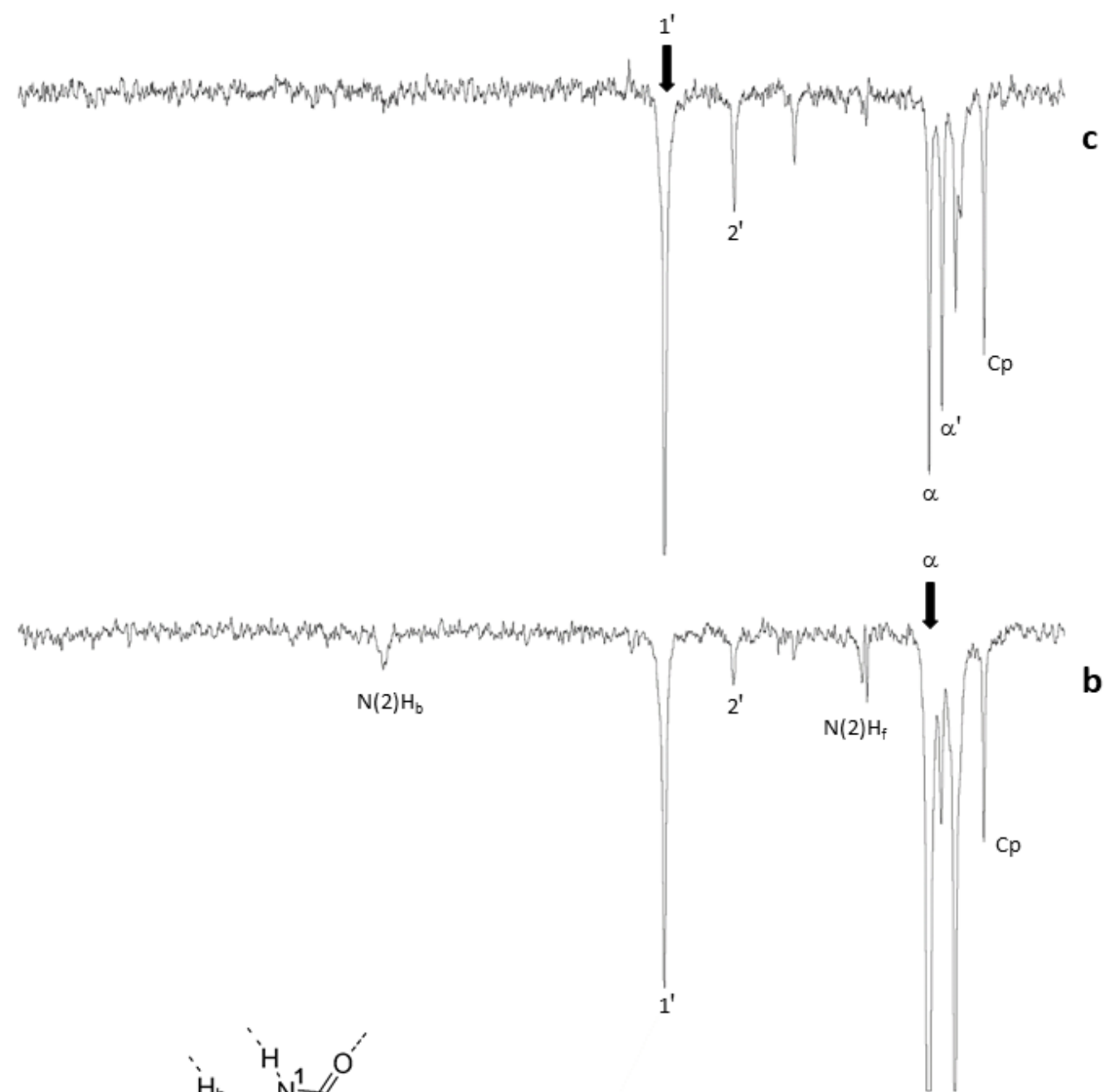

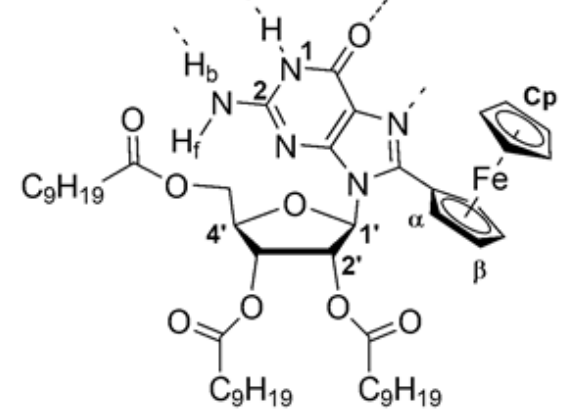

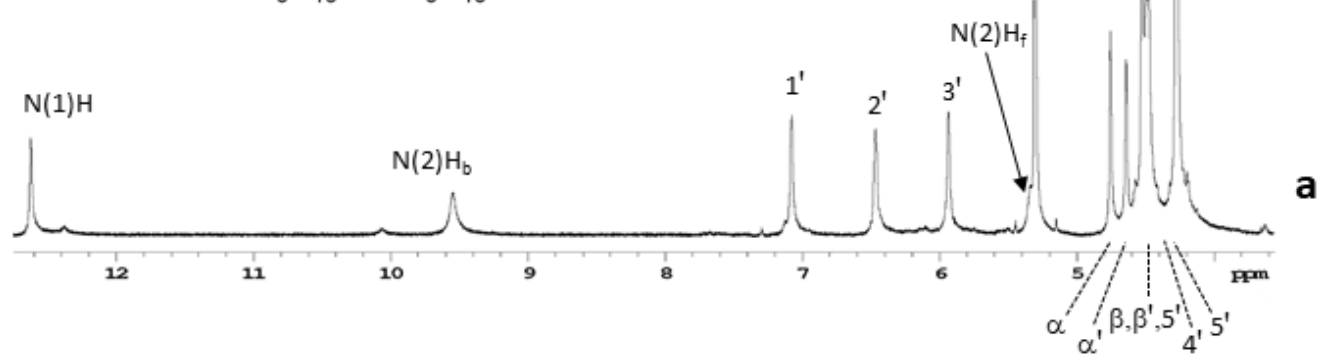

Figure S13. a) Downfield portion of the $600 \mathrm{MHz}{ }^{1} \mathrm{H}-\mathrm{NMR}$ spectrum of $\mathbf{8 F c 5 C 1 0}$ in $\mathrm{CD}_{2} \mathrm{Cl}_{2}(4.5 \mathrm{mM})$ and signals assignment (diastereotopic protons were not assigned); b), c): selected NOESY-1D spectra of the same sample. Irradiated frequencies are indicated by an arrow. In each NOE spectrum were used 512 coadded transients, a recycle delay of $0.6 \mathrm{sec}$, a mixing time of $0.6 \mathrm{sec}$ and a $50 \mathrm{~Hz}$ shaped pulse. All spectra were recorded at $-40^{\circ} \mathrm{C}$. 


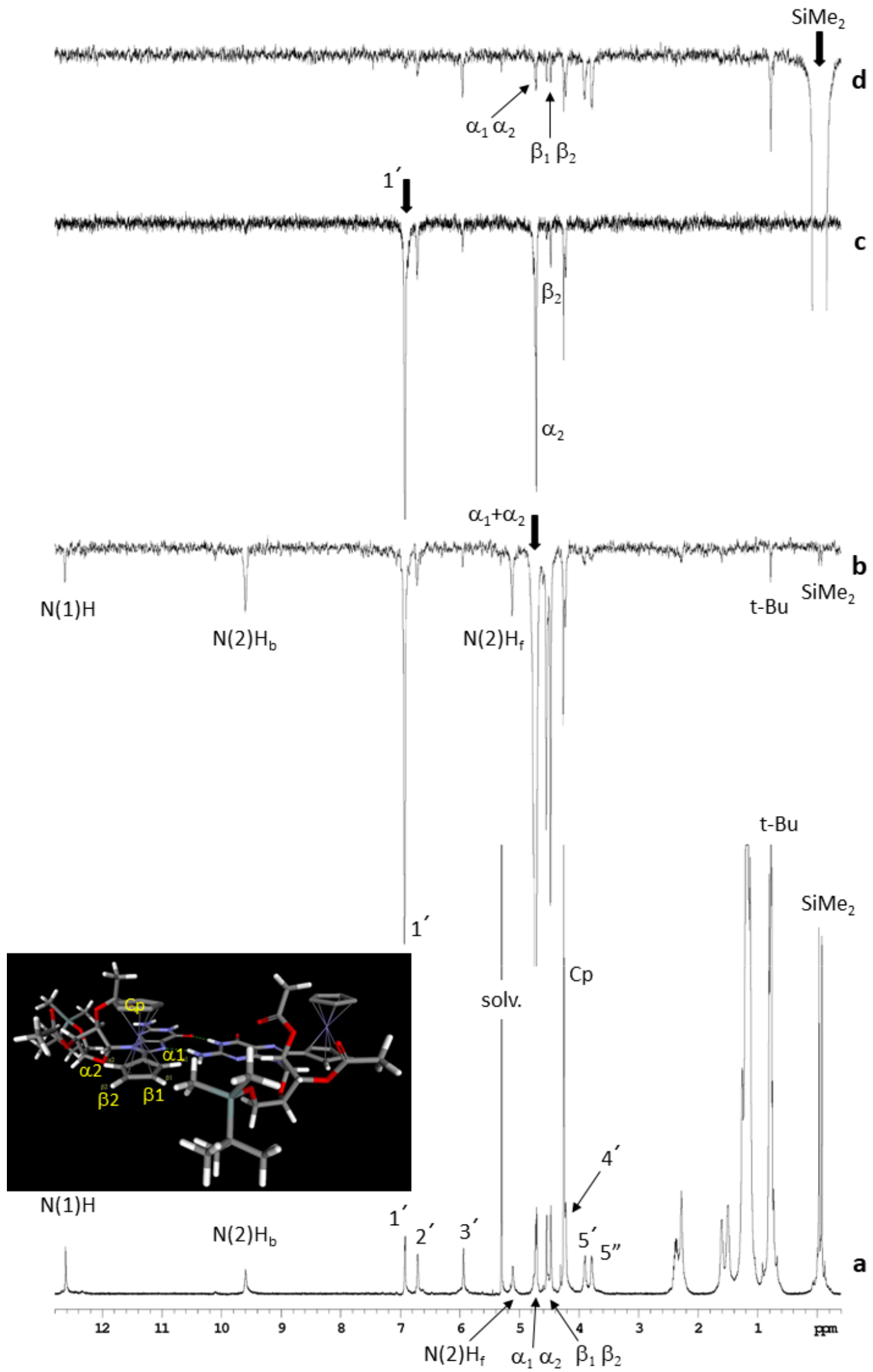

Figure S14. a) $600 \mathrm{MHz}{ }^{1} \mathrm{H}-\mathrm{NMR}$ spectrum of $\mathbf{8 F c 5 S i}$ in $\mathrm{CD}_{2} \mathrm{Cl}_{2}(6 \mathrm{mM})$ and signals assignment (sugar diastereotopic protons were not assigned); b), c), d): selected NOESY-1D spectra of the same sample. Irradiated signals are indicated by an arrow. See inset for proton labeling. In each NOE spectrum were used at least 256 coadded transients, a recycle delay of $1 \mathrm{sec}$, a mixing time of $0.35 \mathrm{sec}$ and a $20-80 \mathrm{~Hz}$ shaped pulse. All spectra were recorded at $-50^{\circ} \mathrm{C}$. 


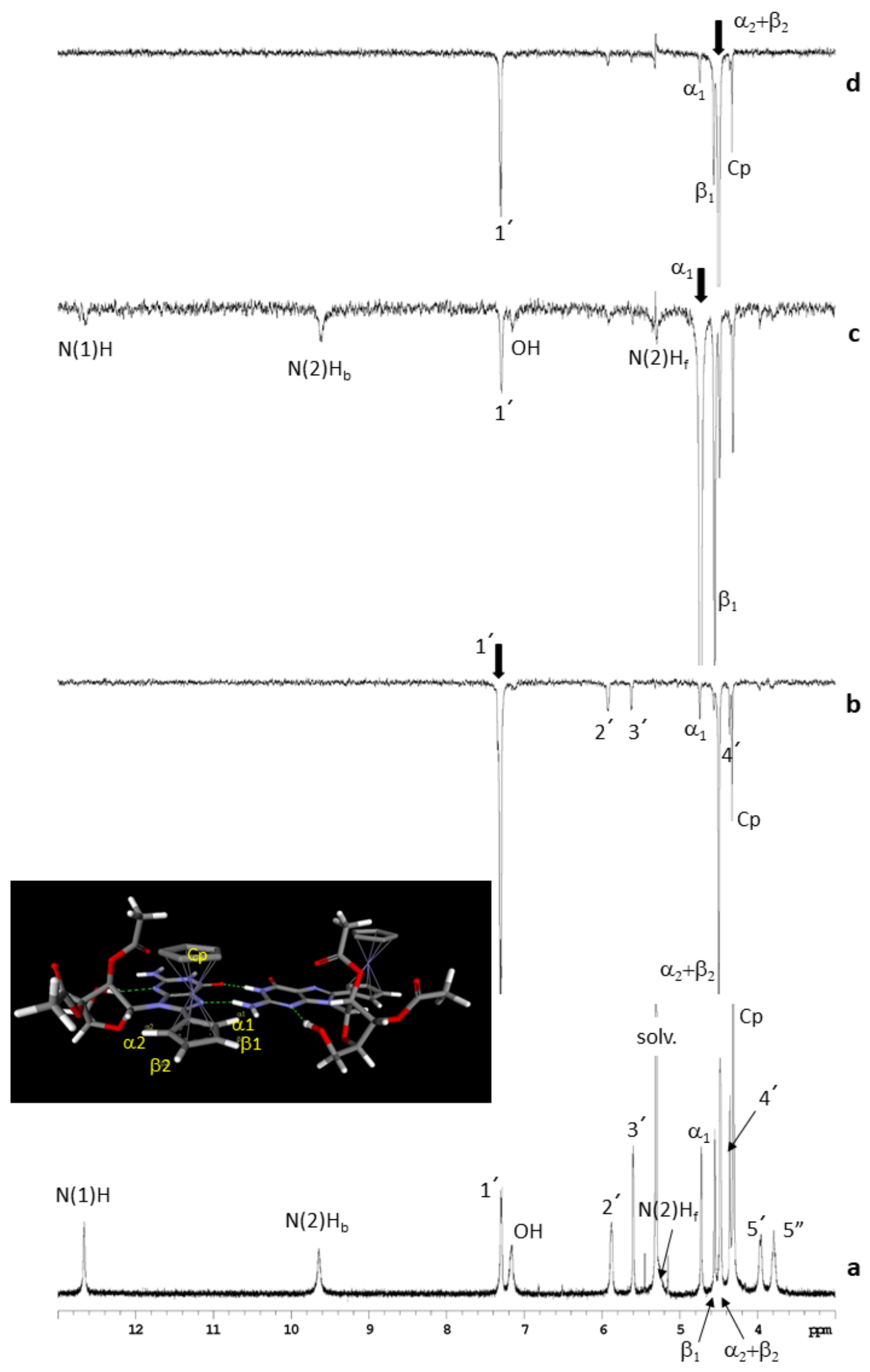

Figure S15. a) Downfield portion of the $600 \mathrm{MHz}{ }^{1} \mathrm{H}-\mathrm{NMR}$ spectrum of $\mathbf{8 F c 5 O H}$ in $\mathrm{CD}_{2} \mathrm{Cl}_{2}(7 \mathrm{mM})$ and signals assignment (ribose diastereotopic protons were not assigned); b), c), d): selected NOESY-1D spectra of the same sample. Irradiated frequencies are indicated by an arrow. See inset for proton labeling. In each NOE spectrum were used at least 128 coadded transients, a recycle delay of $1 \mathrm{sec}$, a mixing time of $0.4 \mathrm{sec}$ and a $20-50 \mathrm{~Hz}$ shaped pulse. All spectra were recorded at $-50^{\circ} \mathrm{C}$. 


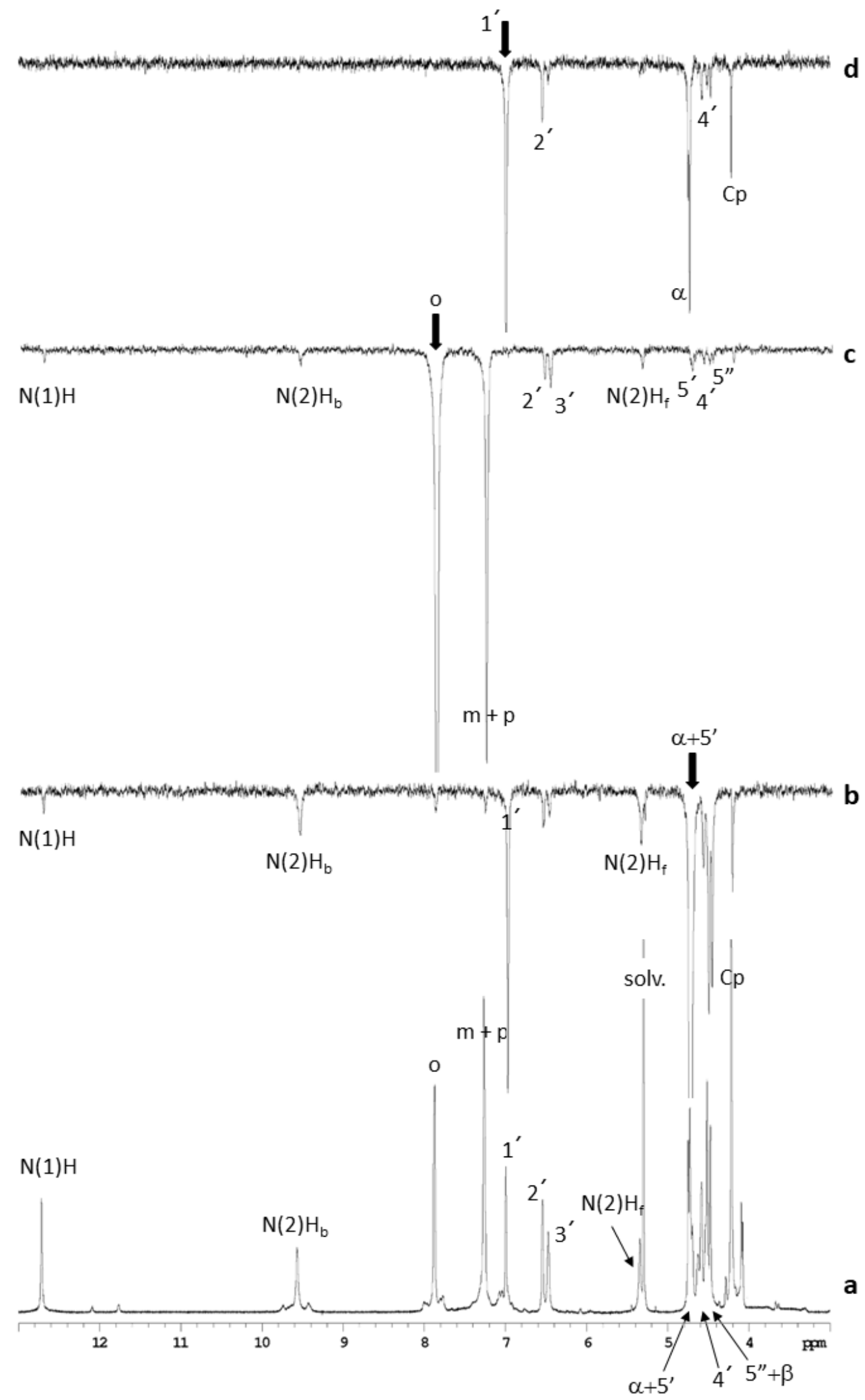

Figure S16. a) Downfield portion of the $600 \mathrm{MHz}{ }^{1} \mathrm{H}-\mathrm{NMR}$ spectrum of $\mathbf{8 F c 5 P h}$ in $\mathrm{CD}_{2} \mathrm{Cl}_{2}(4 \mathrm{mM})$ and signals assignment (diastereotopic protons were not assigned); b), c), d): selected NOESY-1D spectra of the same sample. Irradiated protons are indicated by an arrow. In each NOE spectrum were used at least 256 coadded transients, a recycle delay of $1 \mathrm{sec}$, a mixing time of $0.4 \mathrm{sec}$ and a $20-50 \mathrm{~Hz}$ shaped pulse. All spectra were recorded at $-50^{\circ} \mathrm{C}$. 

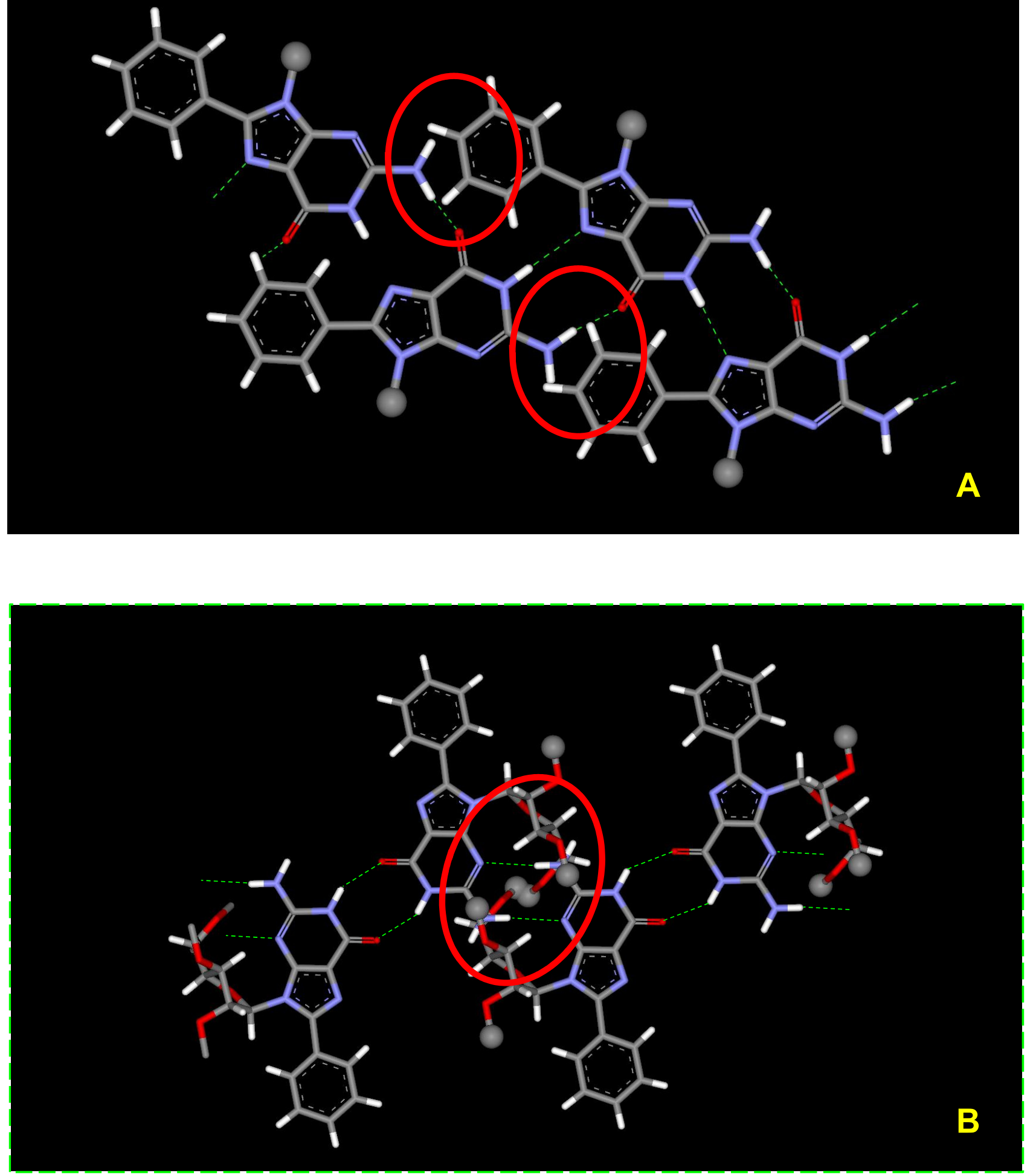

Figure S17. Sketches of ribbon-like structures A and B hypothetically formed by 8-substituted guanosine in syn conformation. Sterically overcrowded areas are circled. Furthermore, both structures are incompatible with observed NOEs. 


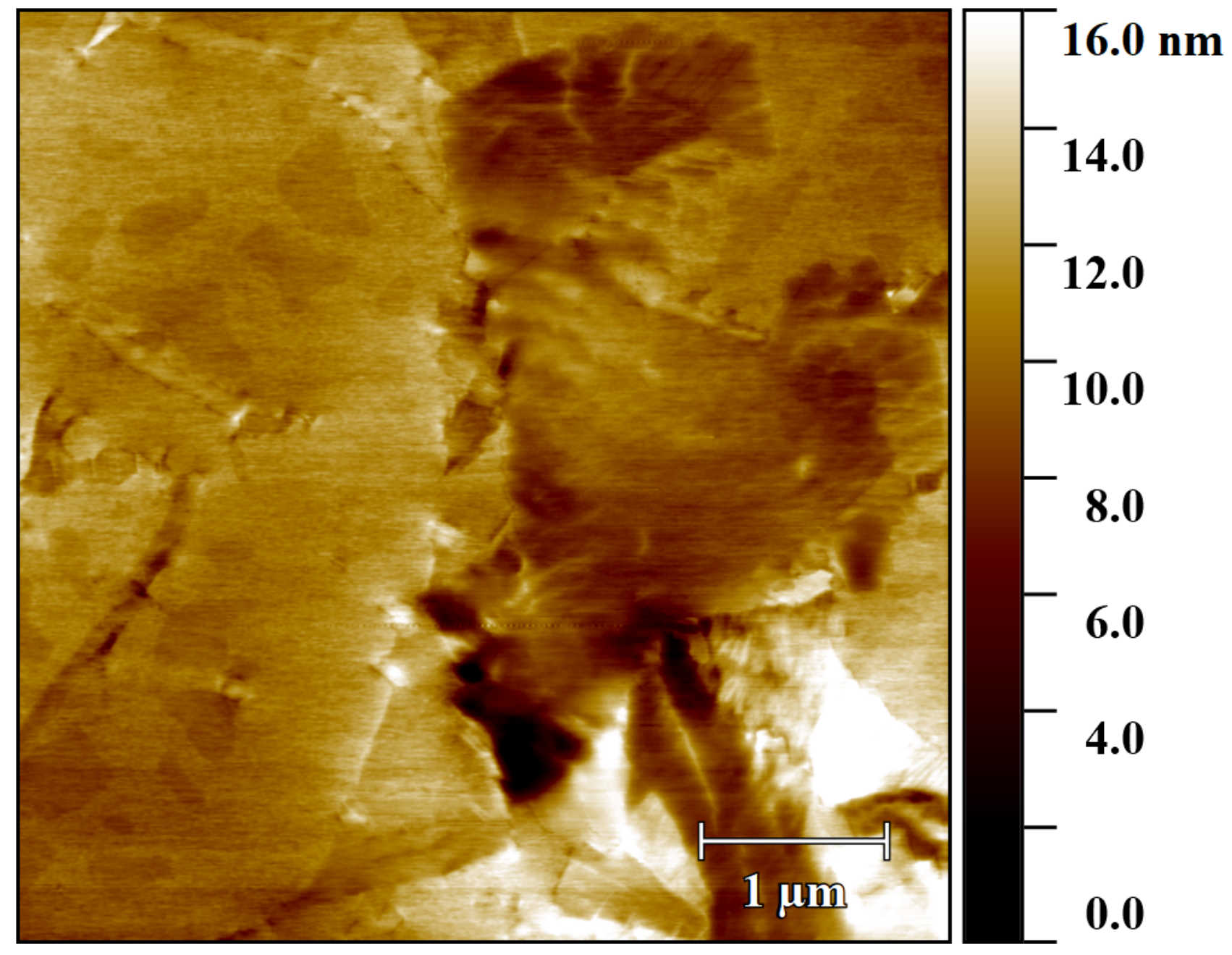

Figure S18. AFM image of the amorphous film obtained from $8 \mathrm{Ph5C10}$ by drop-casting from $\mathrm{CH}_{2} \mathrm{Cl}_{2}$. 


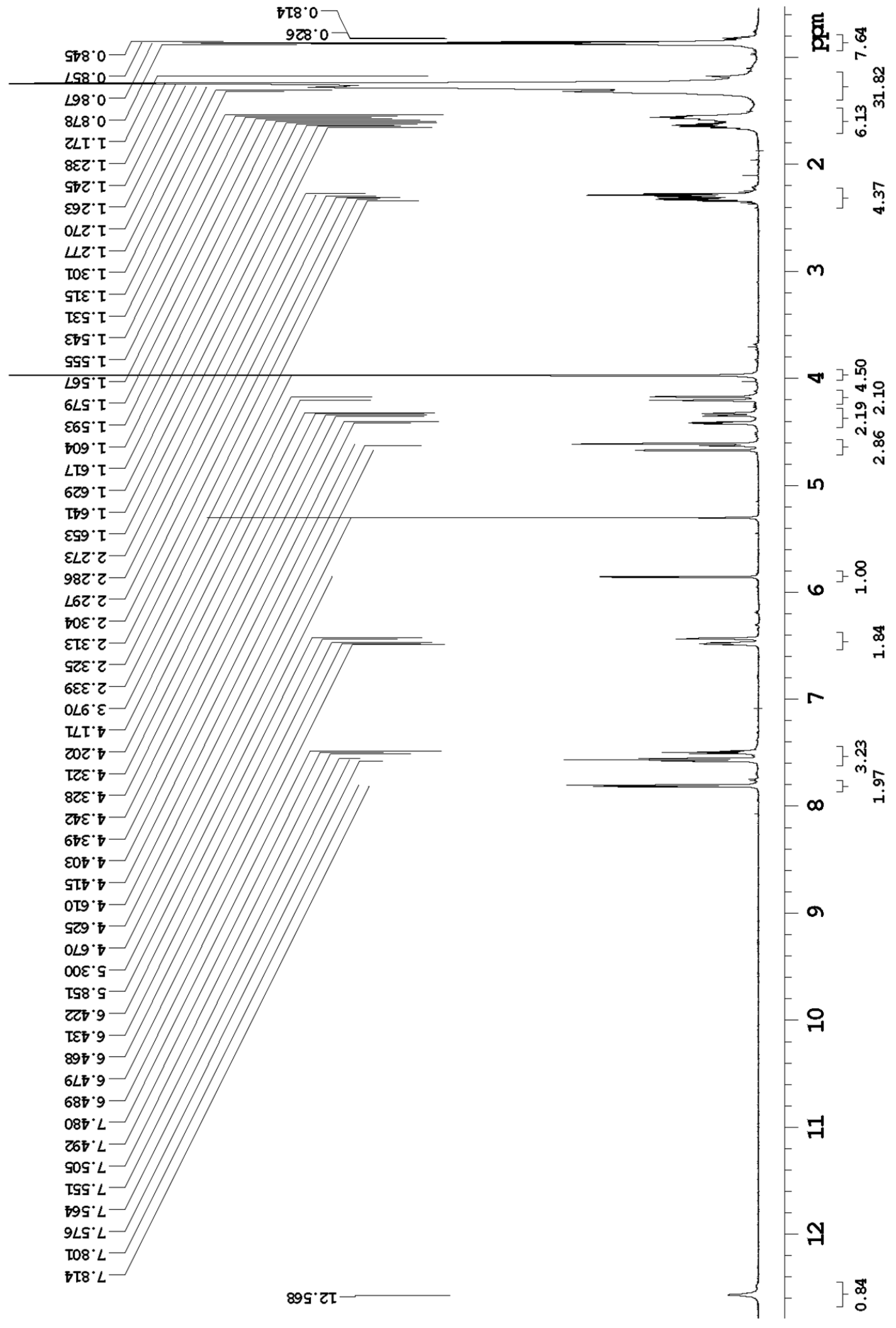

${ }^{1} \mathrm{H}-\mathrm{NMR}\left(\mathrm{CD}_{2} \mathrm{Cl}_{2}, 600 \mathrm{MHz}\right)$ of $8 \mathbf{P h} 5 \mathbf{F c}$ 


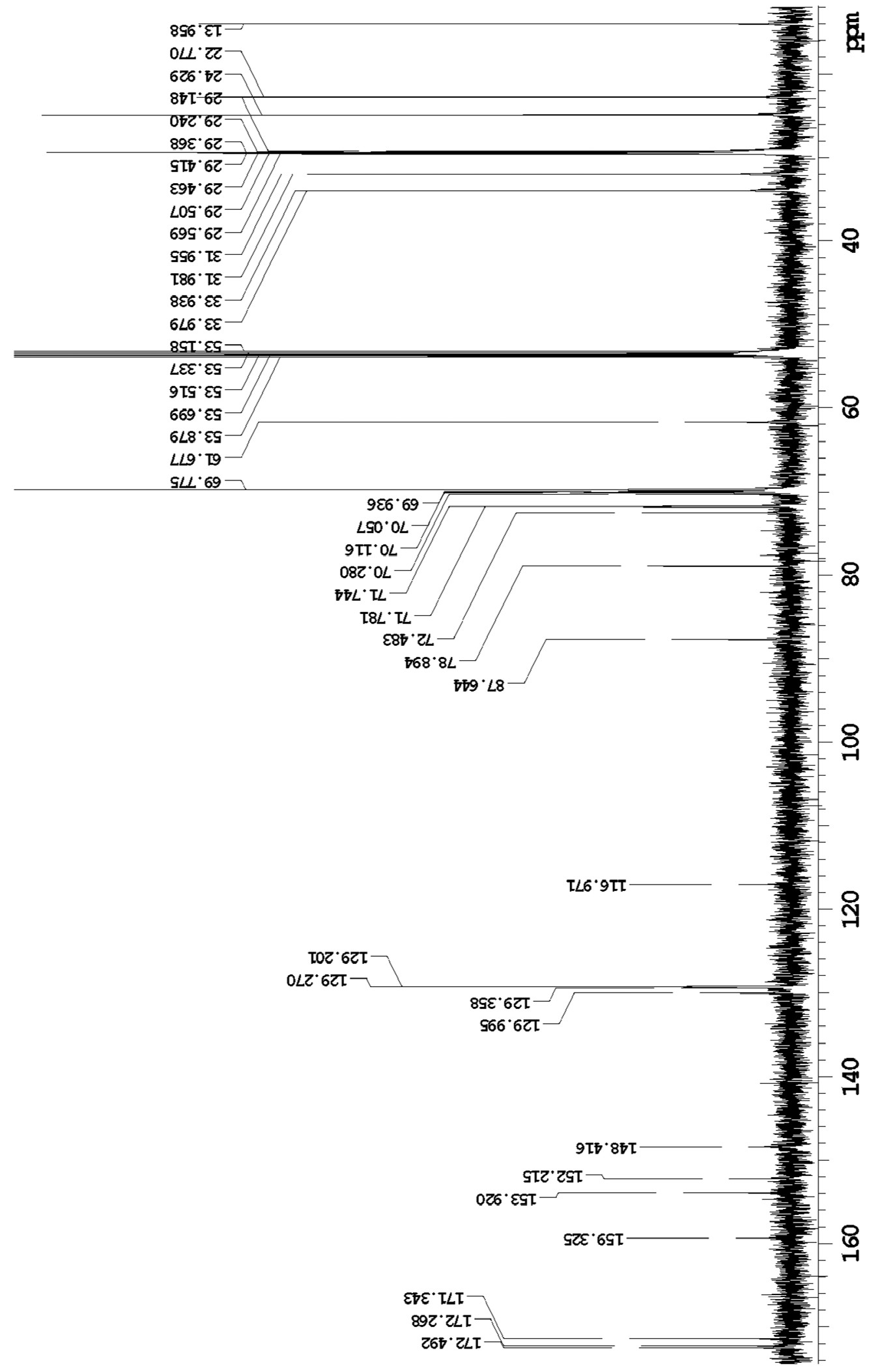

${ }^{13} \mathrm{C}\{1 \mathrm{H}\} \mathrm{NMR}\left(\mathrm{CD}_{2} \mathrm{Cl} 2,600 \mathrm{MHz}\right)$ of $\mathbf{8 P h 5 F c}$ 


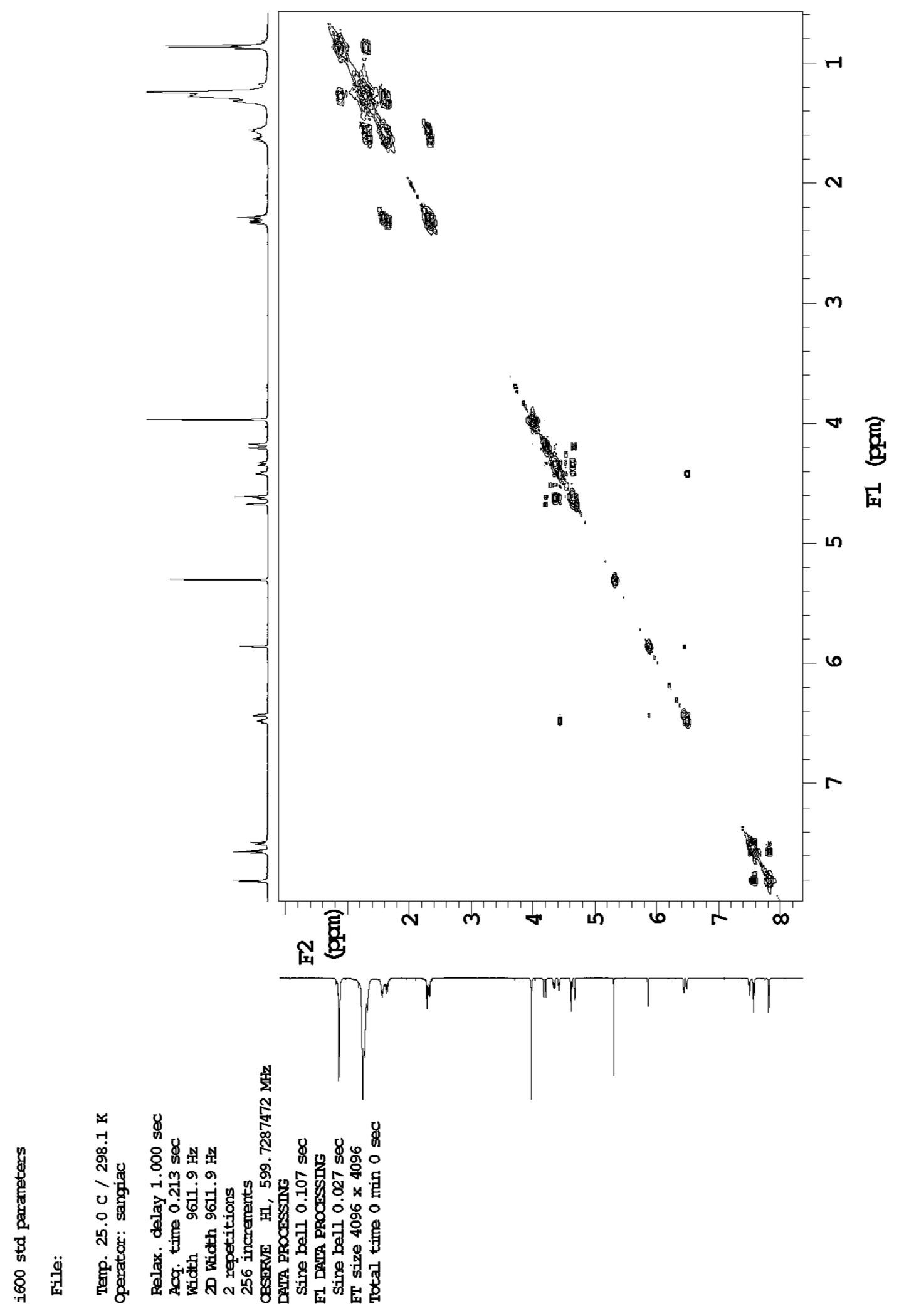

gCOSY spectrum $\left(\mathrm{CD}_{2} \mathrm{Cl}_{2}, 600 \mathrm{MHz}\right)$ of $\mathbf{8 P h 5 F c}$ 


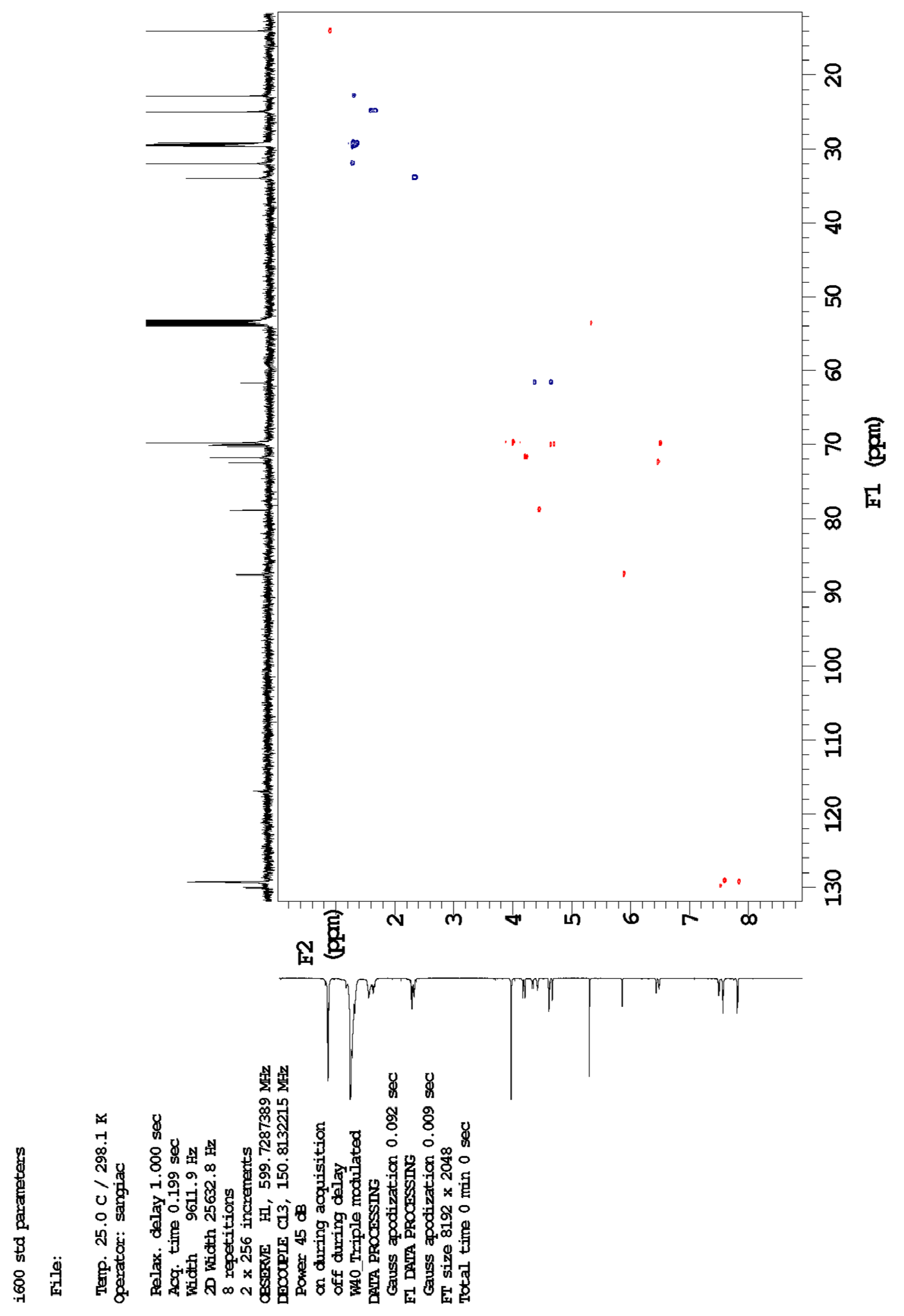

gHSQC spectrum $\left(\mathrm{CD}_{2} \mathrm{Cl}_{2}, 600 \mathrm{MHz}\right)$ of $\mathbf{8 P h 5 F c}$ 


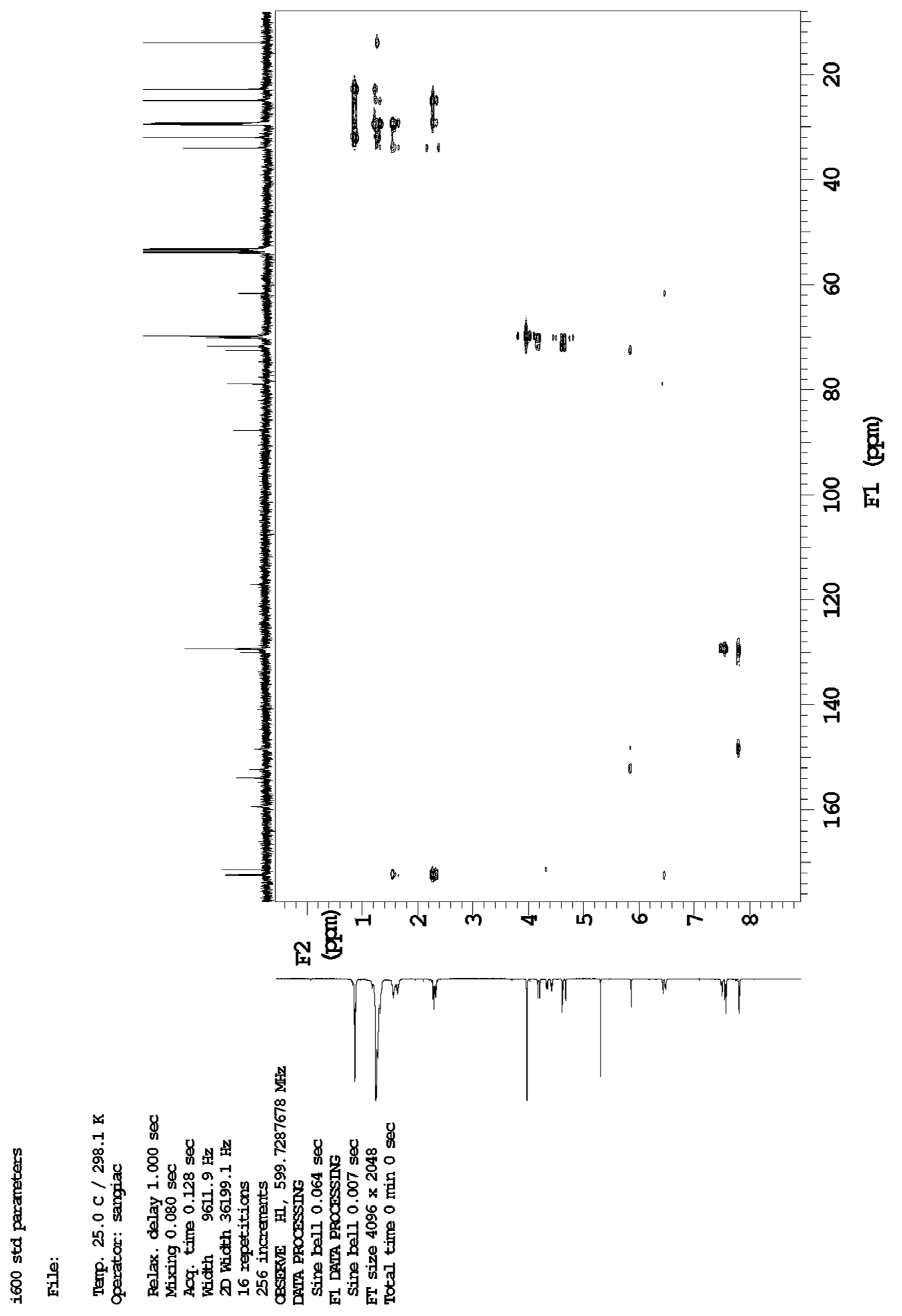

gHMBC spectrum $\left(\mathrm{CD}_{2} \mathrm{Cl}_{2}, 600 \mathrm{MHz}\right)$ of $\mathbf{8 P h 5 F c}$ 


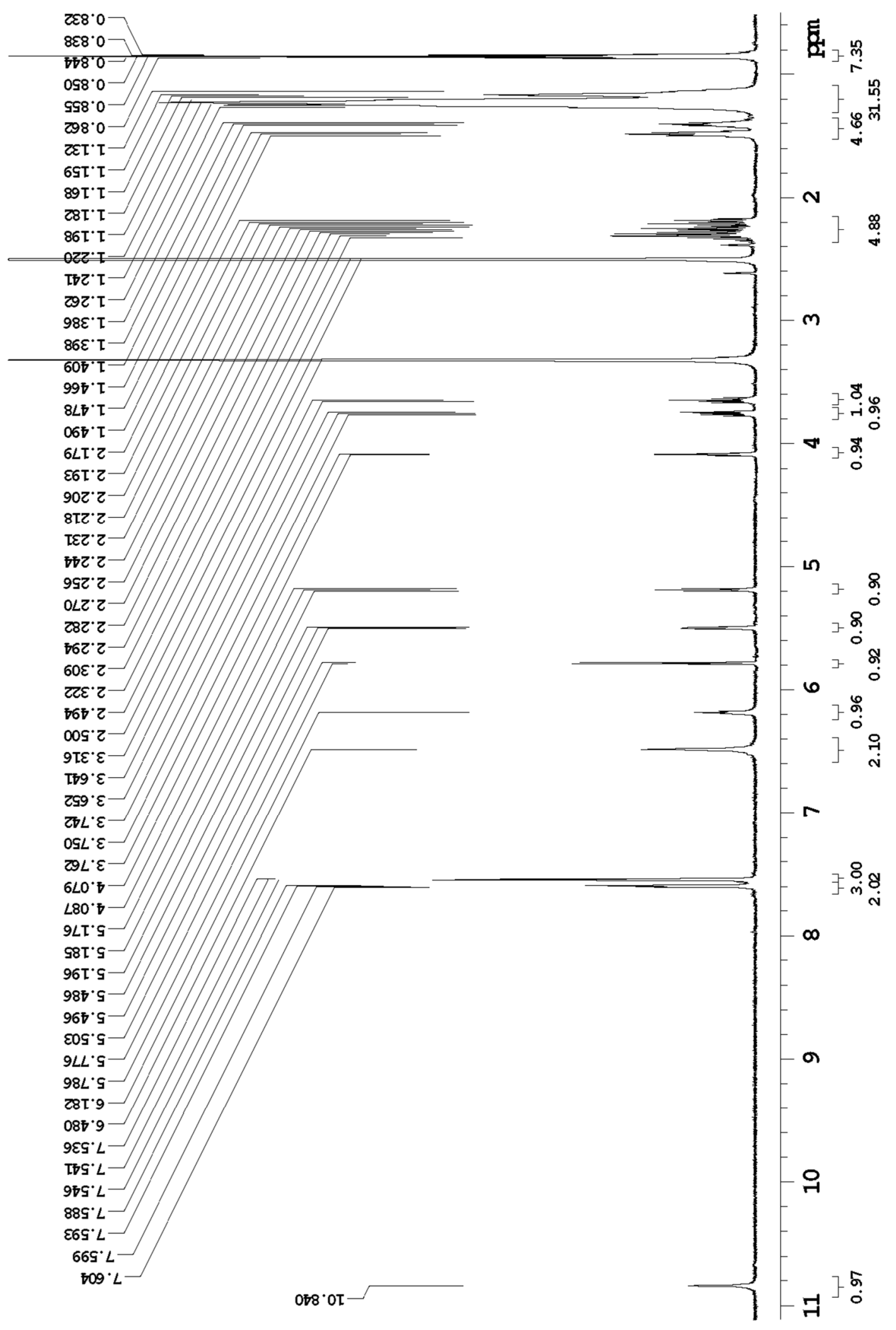

${ }^{1} \mathrm{H}-\mathrm{NMR}$ (dmso-d6, $600 \mathrm{MHz}$ ) of $\mathbf{8 P h 5 O H}$ 


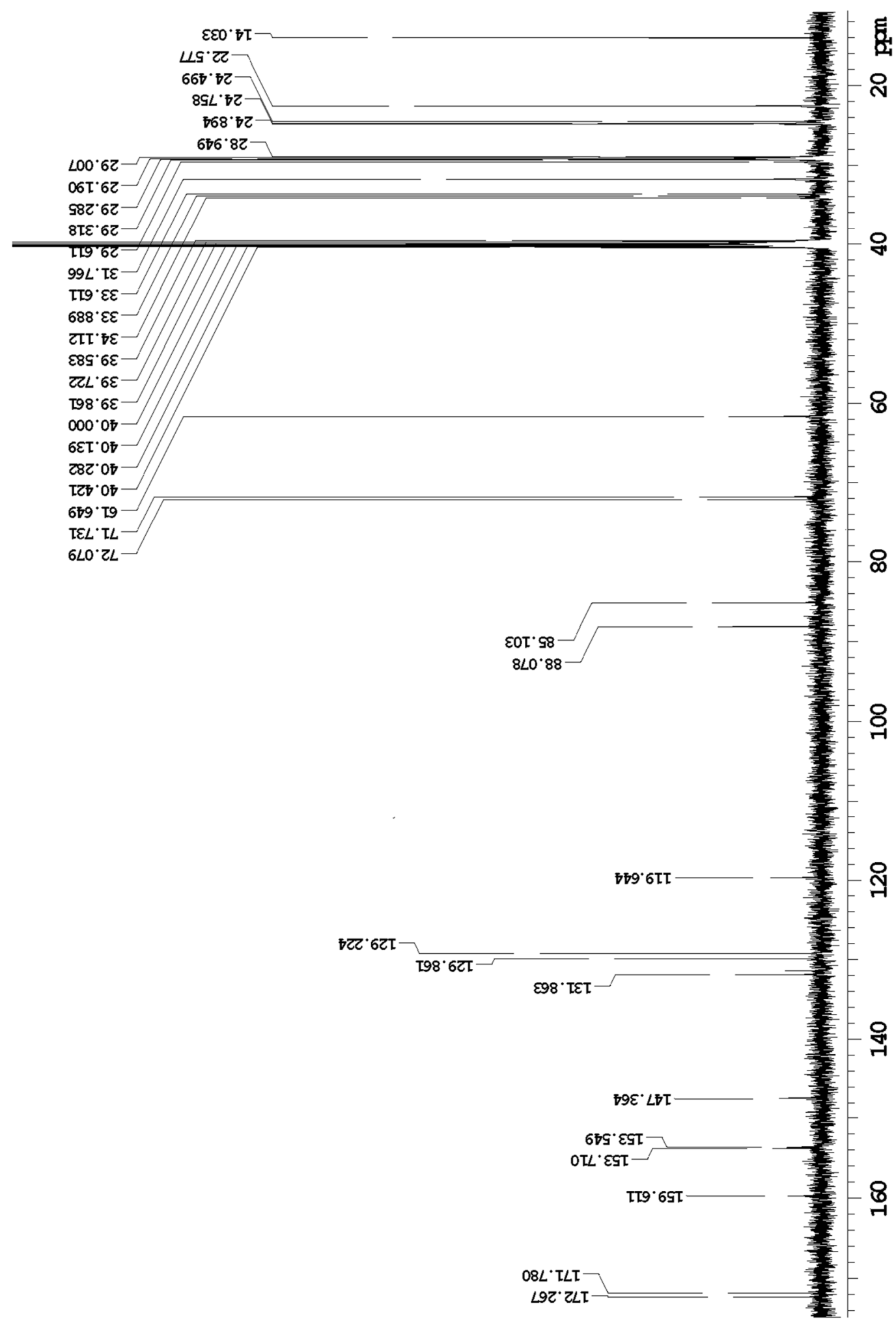

${ }^{13} \mathrm{C}\{1 \mathrm{H}\} \mathrm{NMR}$ (dmso-d6, $600 \mathrm{MHz}$ ) of $\mathbf{8 P h 5 O H}$ 


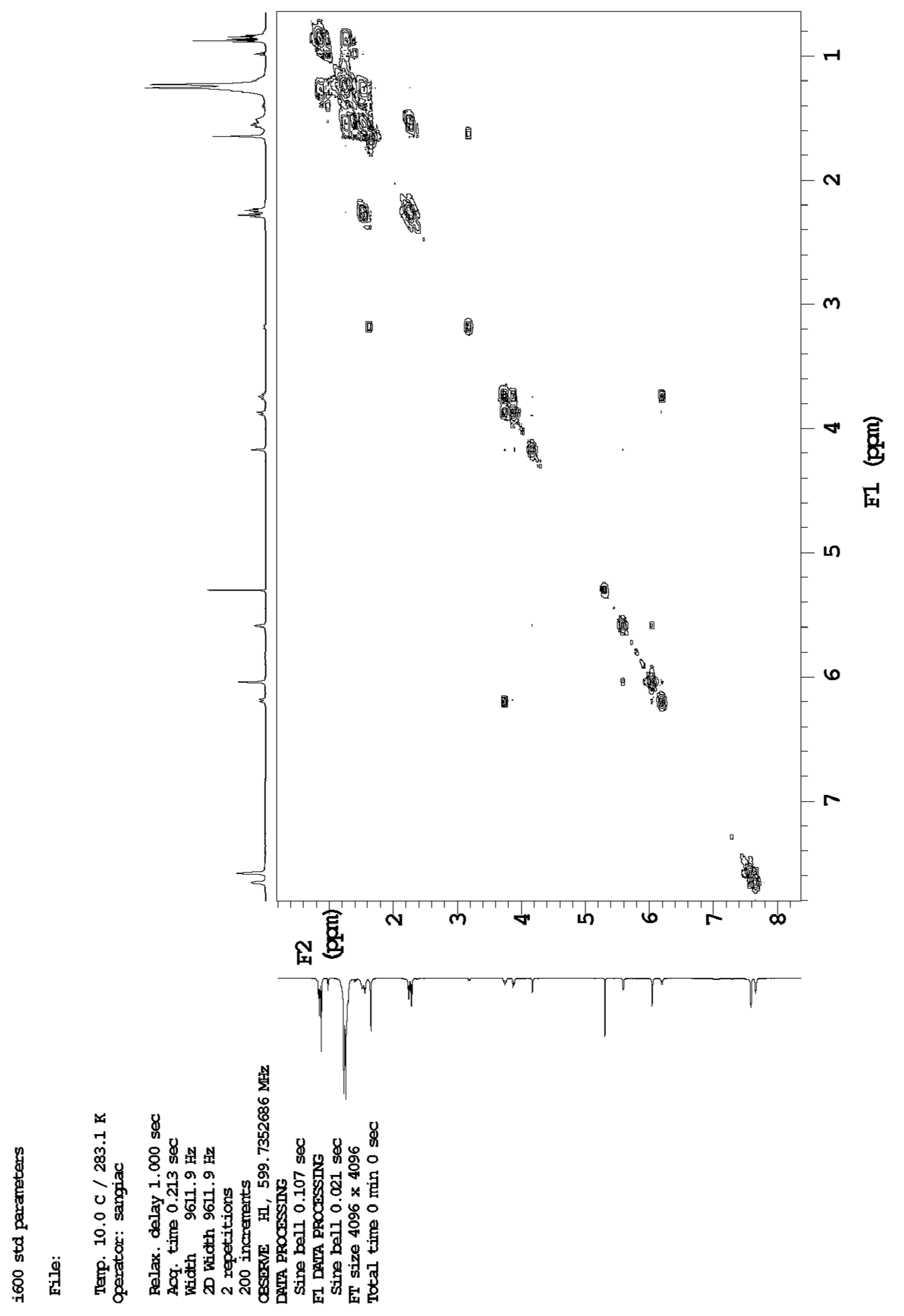

gCOSY spectrum $\left(\mathrm{CD}_{2} \mathrm{Cl}_{2}, 600 \mathrm{MHz}\right)$ of $\mathbf{8 P h 5 O H}$ 


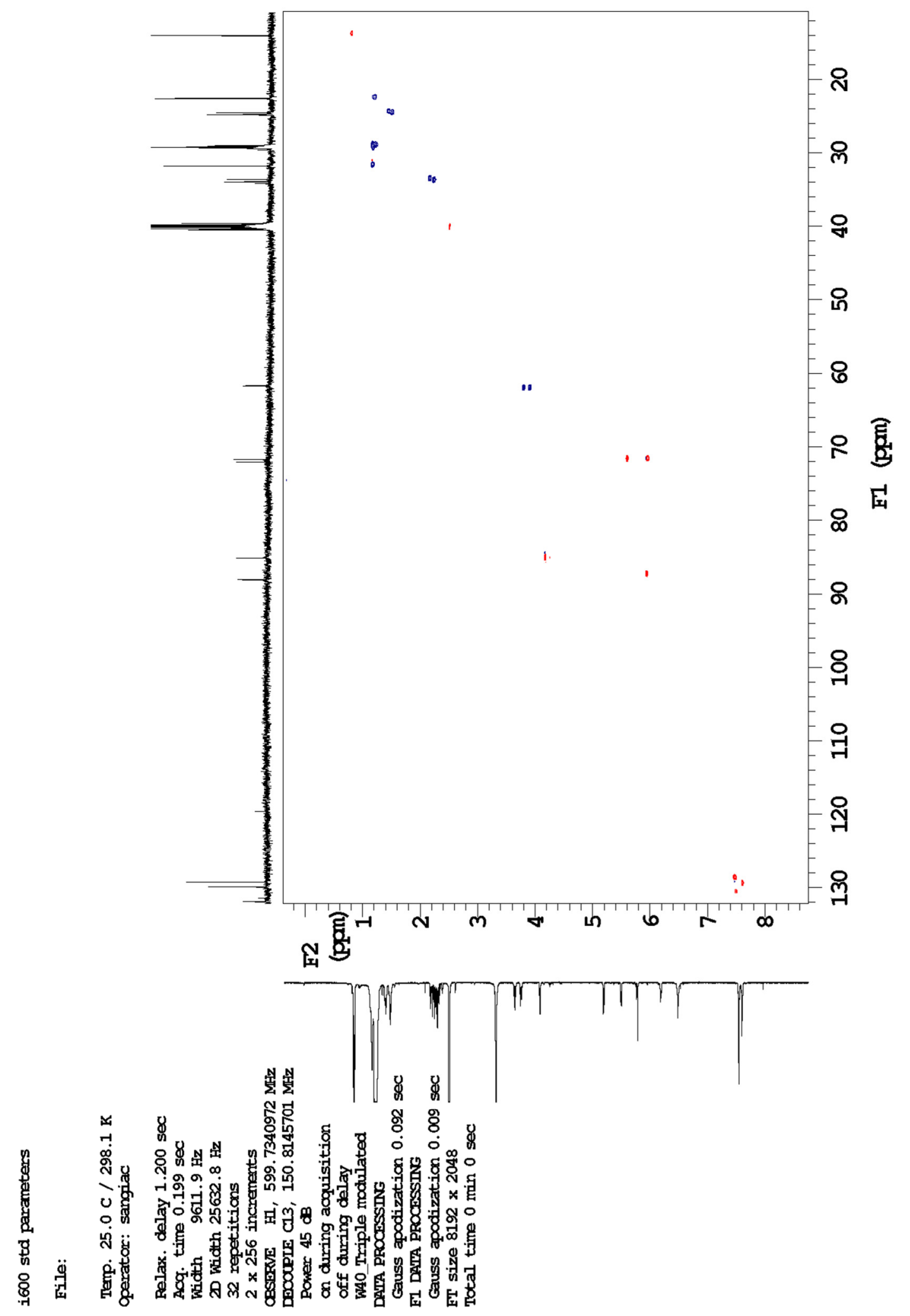

gHSQC spectrum (dmso-d6, $600 \mathrm{MHz}$ ) of $\mathbf{8 P h 5 0 H}$ 


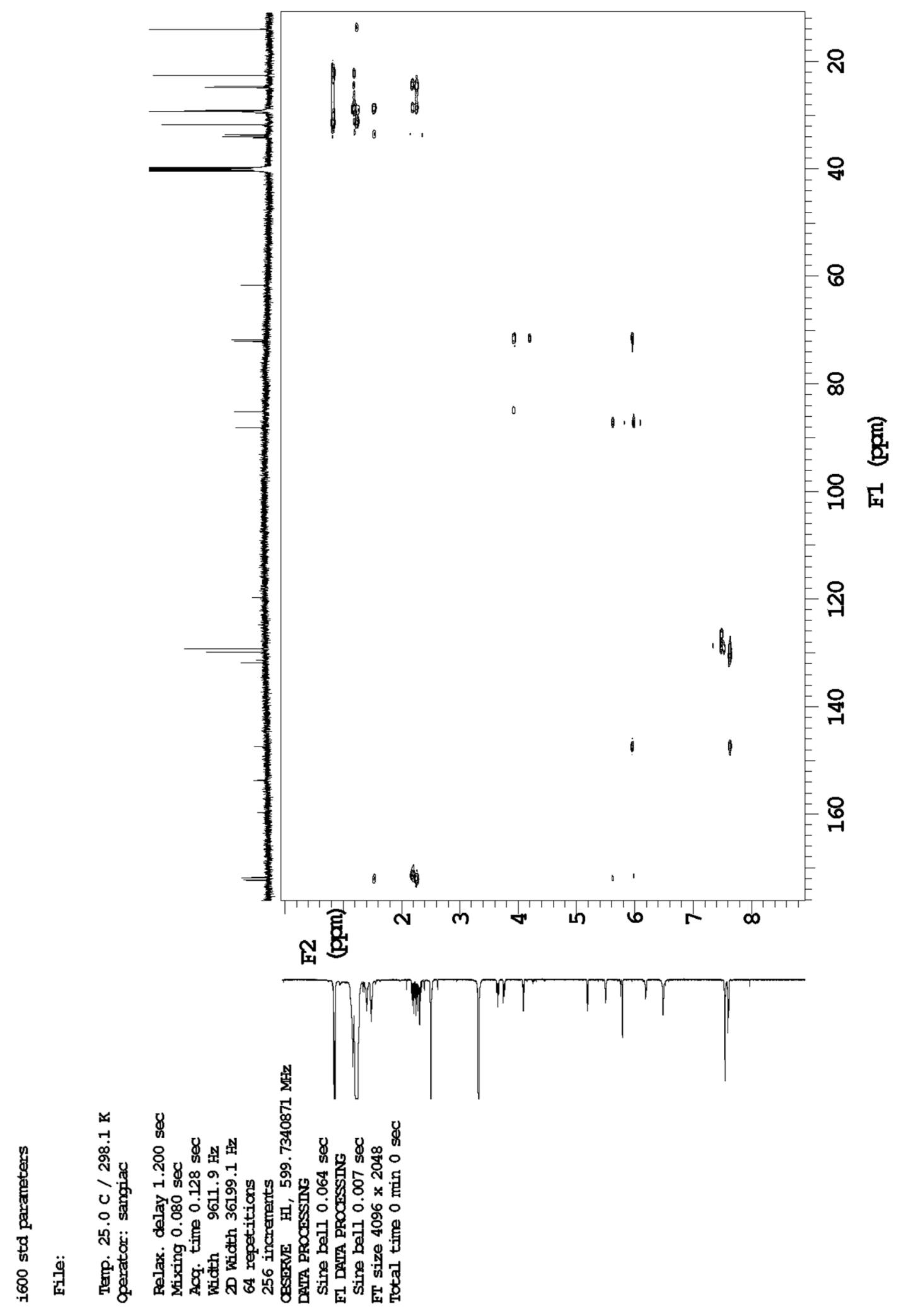

gHMBC spectrum (dmso-d6, $600 \mathrm{MHz}$ ) of $\mathbf{8 P h 5 0 H}$ 


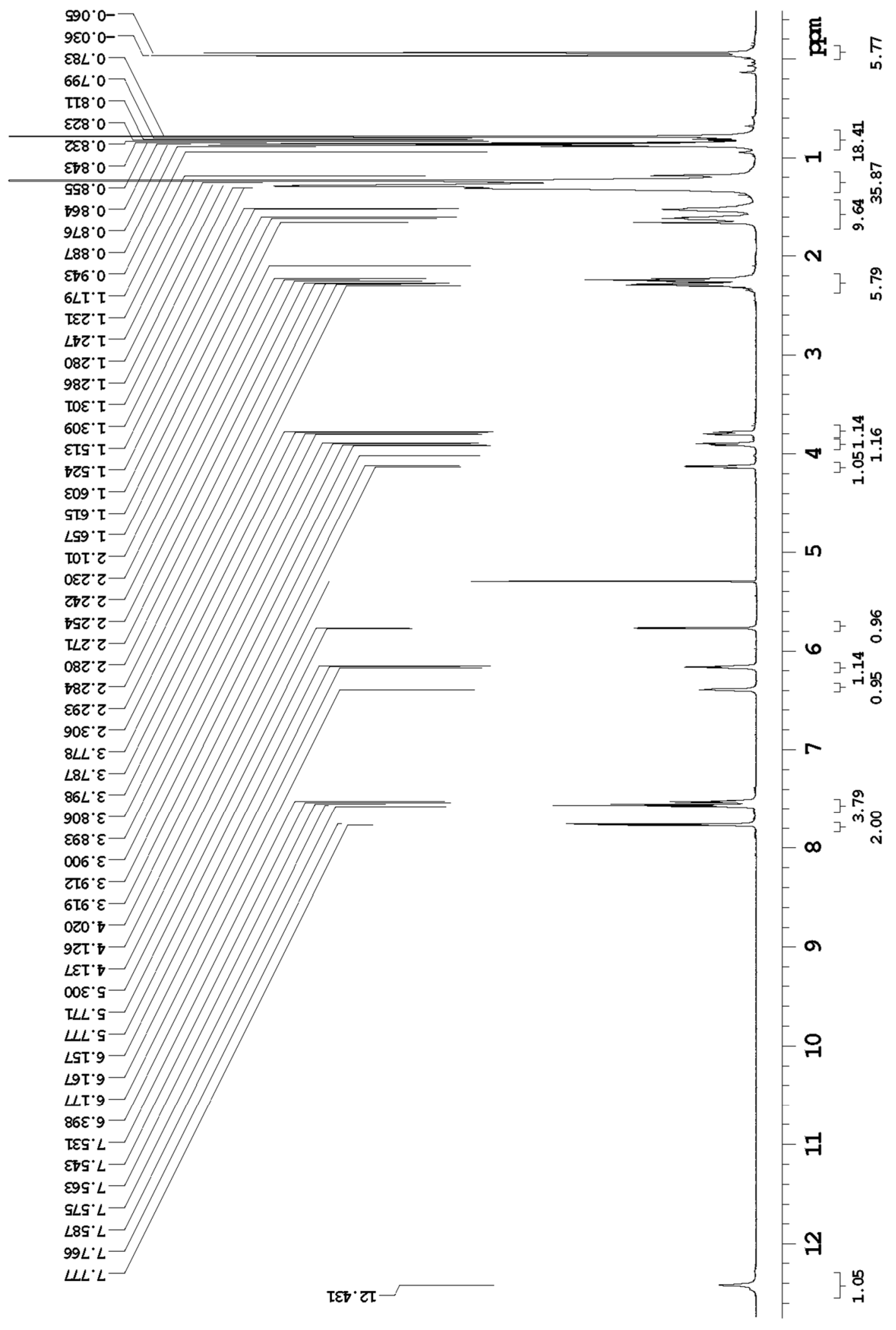

${ }^{1} \mathrm{H}-\mathrm{NMR}\left(\mathrm{CD}_{2} \mathrm{Cl}_{2}, 600 \mathrm{MHz}\right)$ of $\mathbf{8 P h} 5 \mathrm{Si}$ 


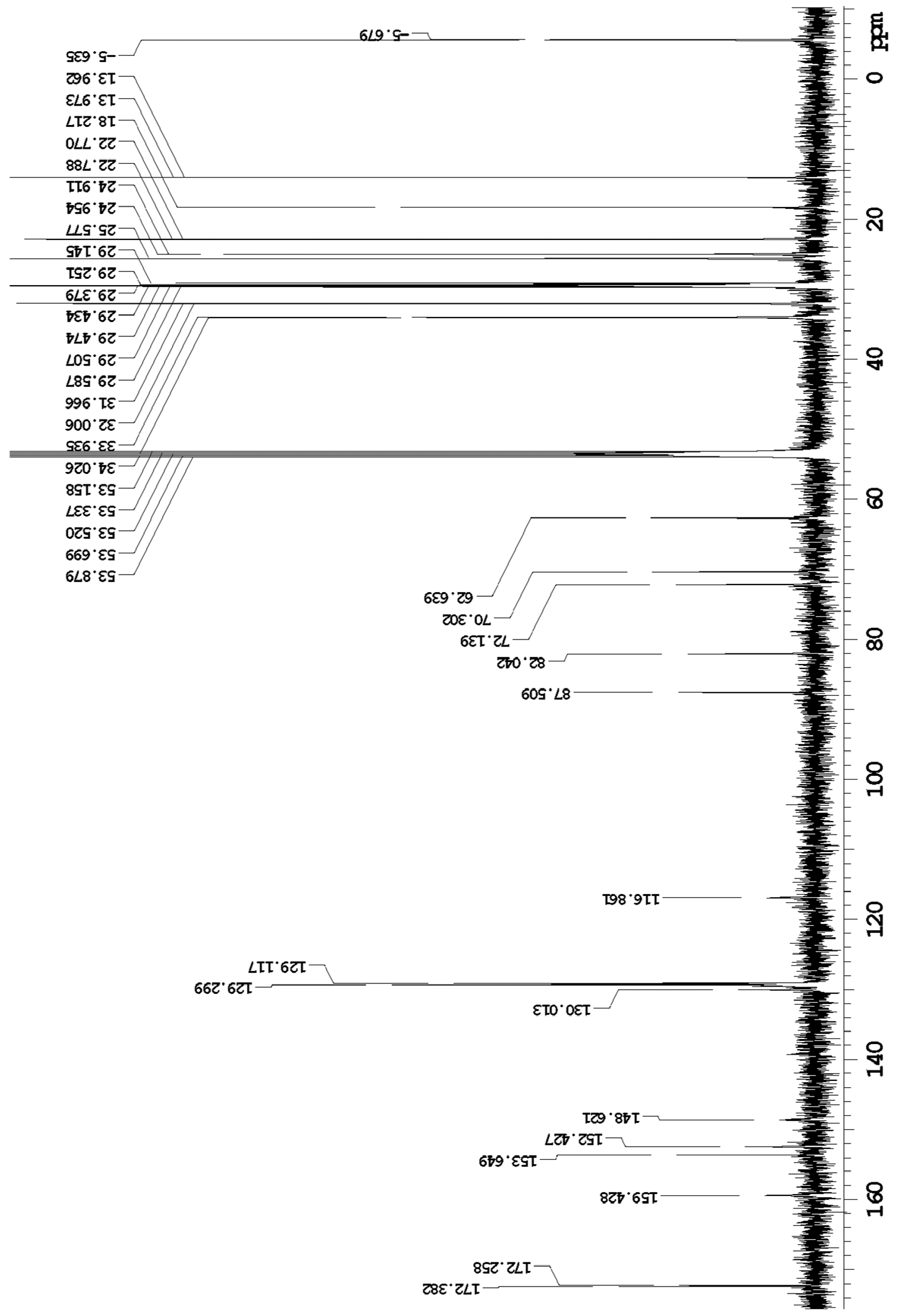

${ }^{13} \mathrm{C}\{1 \mathrm{H}\} \mathrm{NMR}\left(\mathrm{CD}_{2} \mathrm{Cl}_{2}, 600 \mathrm{MHz}\right)$ of $\mathbf{8 P h} 5 \mathrm{Si}$ 


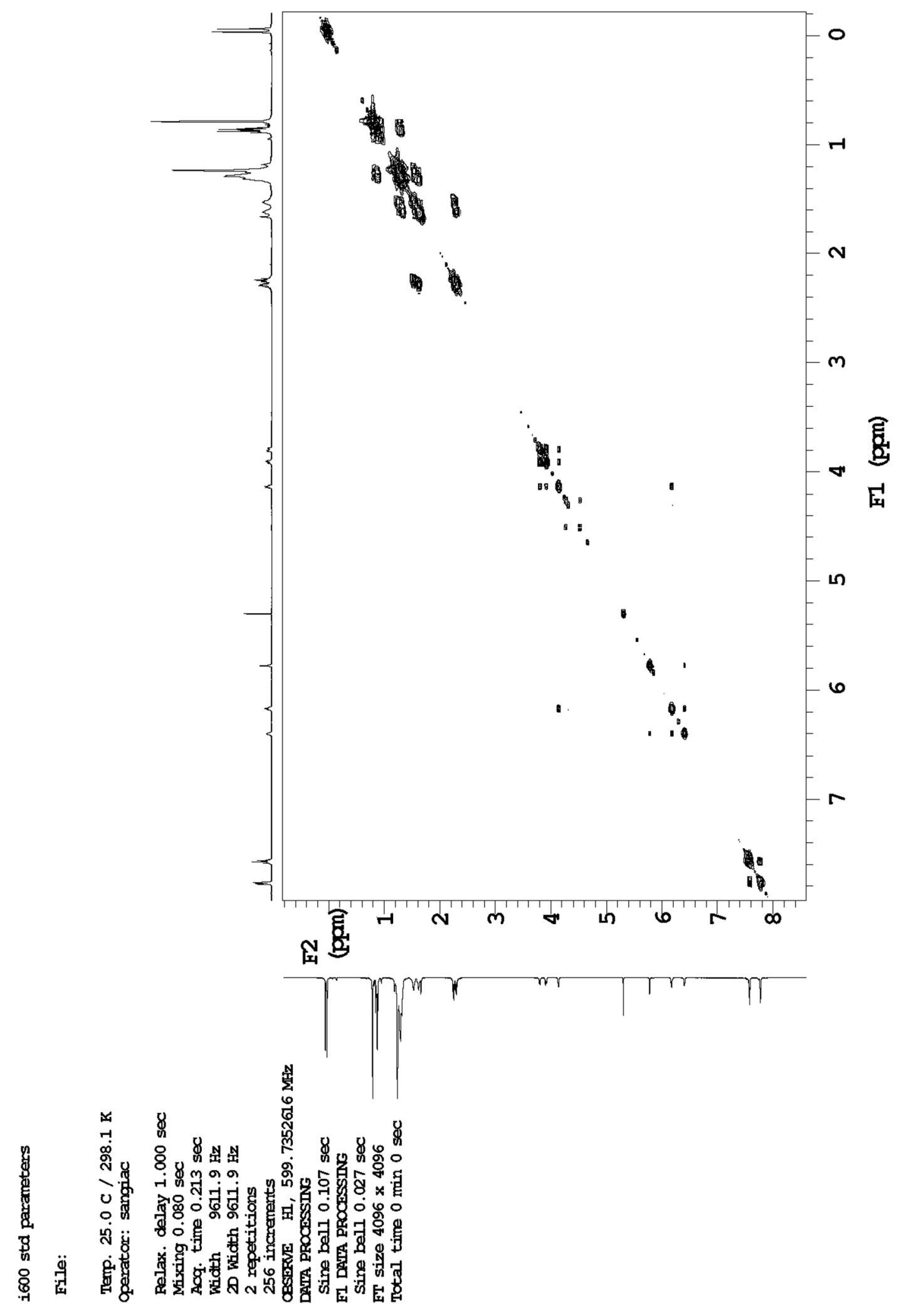

gCOSY spectrum $\left(\mathrm{CD}_{2} \mathrm{Cl}_{2}, 600 \mathrm{MHz}\right)$ of $\mathbf{8 P h 5 S i}$ 


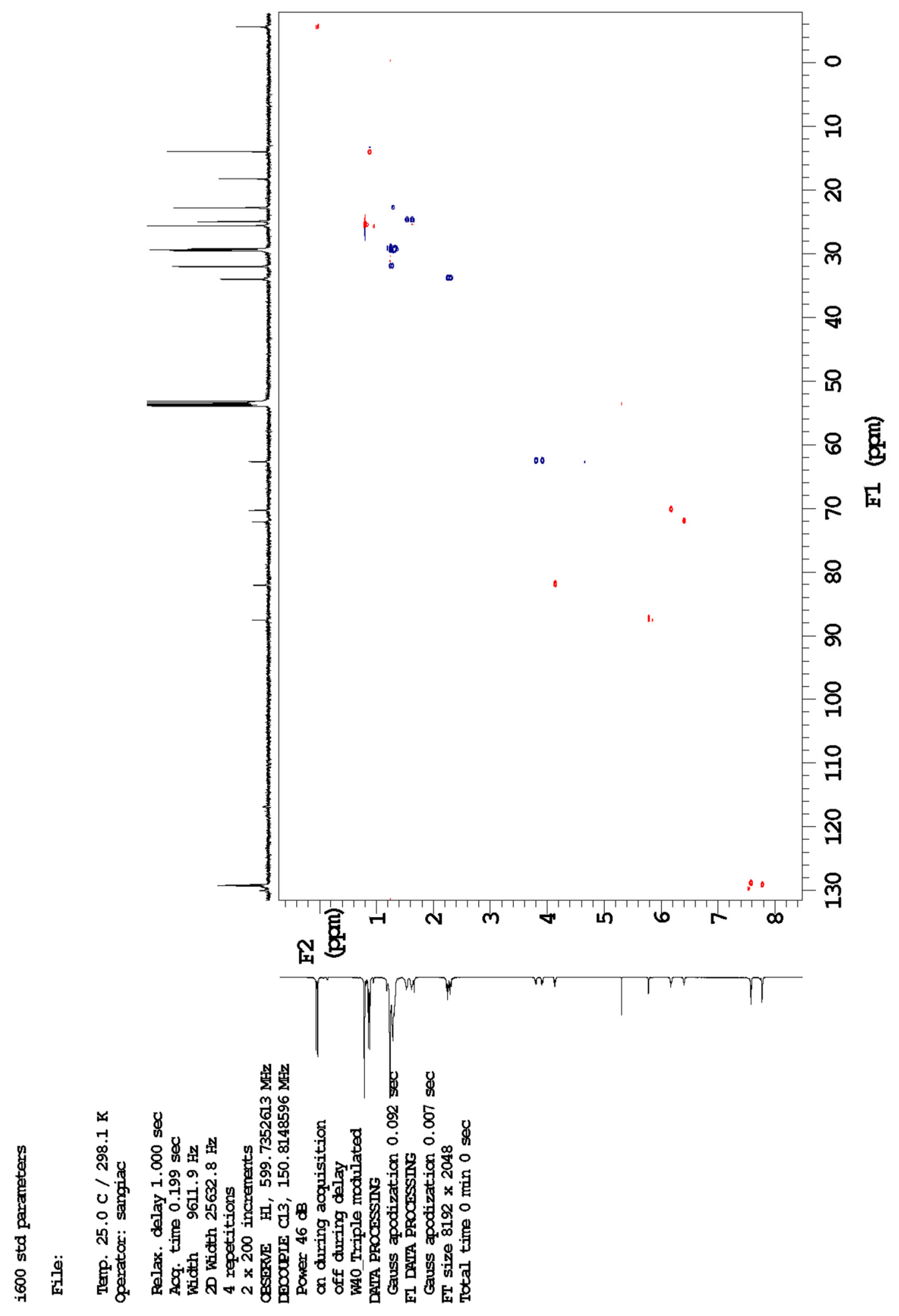

gHSQC spectrum $\left(\mathrm{CD}_{2} \mathrm{Cl}_{2}, 600 \mathrm{MHz}\right)$ of $\mathbf{8 P h 5 S i}$ 


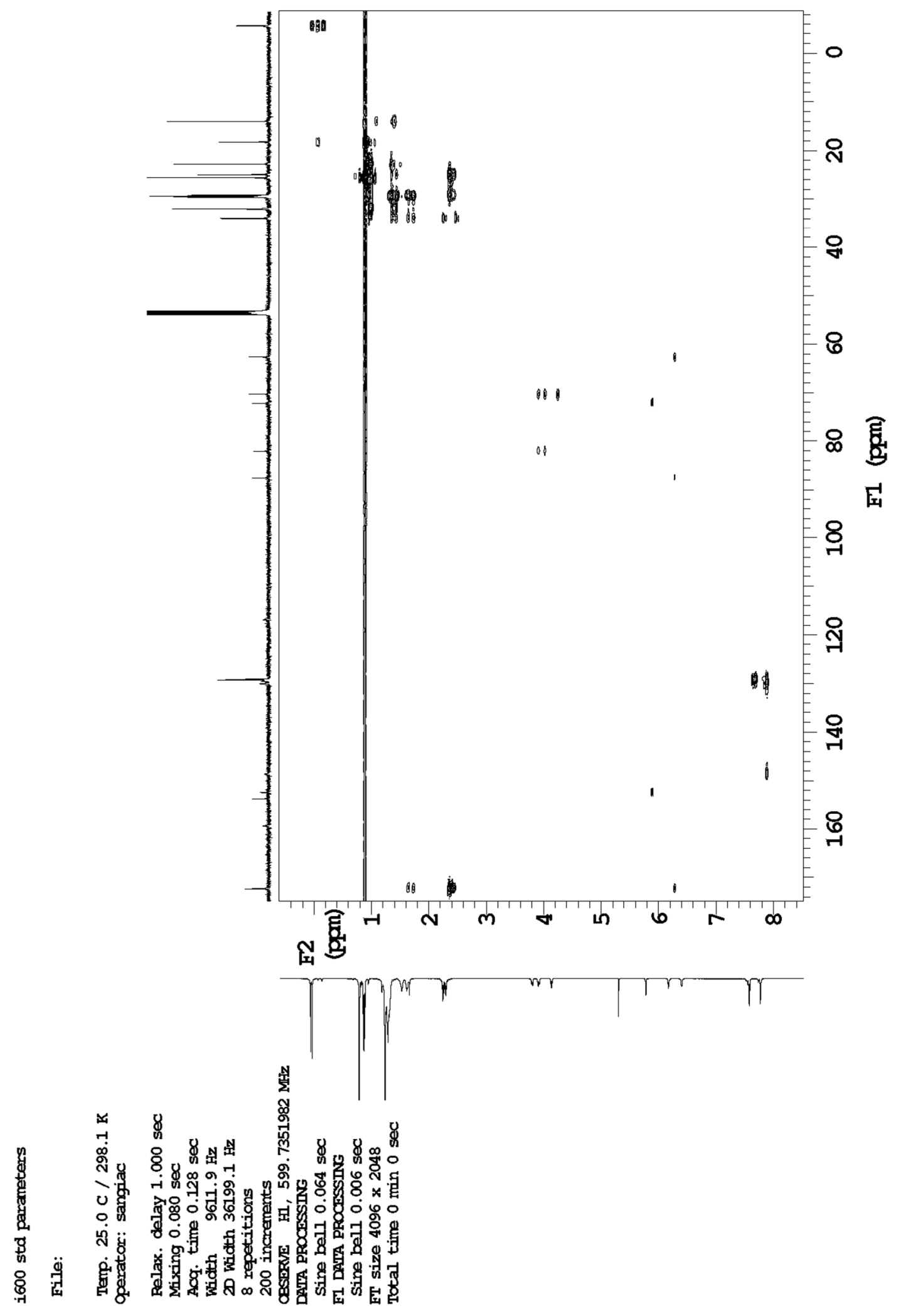

gHMBC spectrum $\left(\mathrm{CD}_{2} \mathrm{Cl}_{2}, 600 \mathrm{MHz}\right)$ of $\mathbf{8 P h 5 S i}$ 


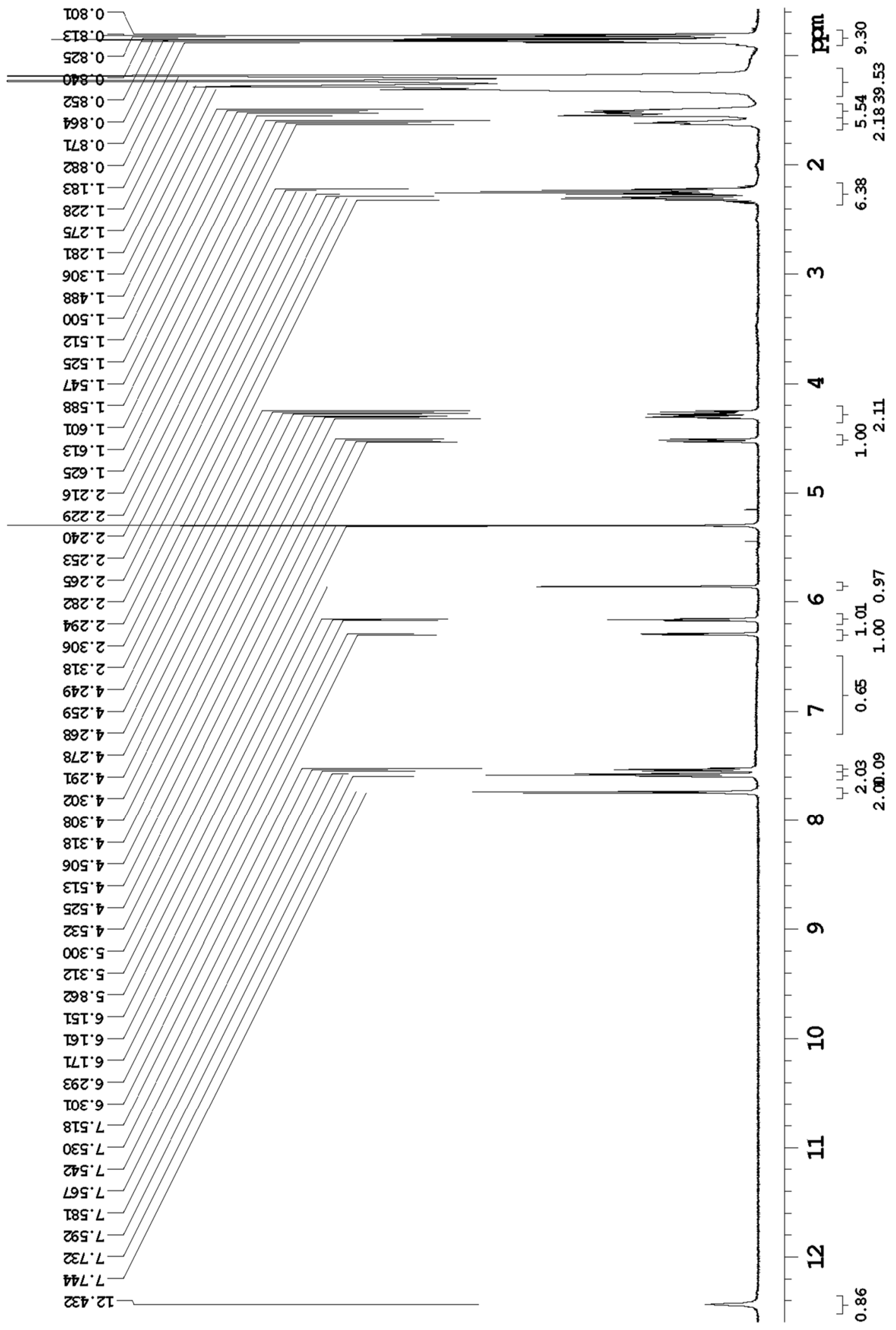

${ }^{1} \mathrm{H}-\mathrm{NMR}\left(\mathrm{CD}_{2} \mathrm{Cl}_{2}, 600 \mathrm{MHz}\right)$ of $\mathbf{8 P h 5 C 1 0}$ 


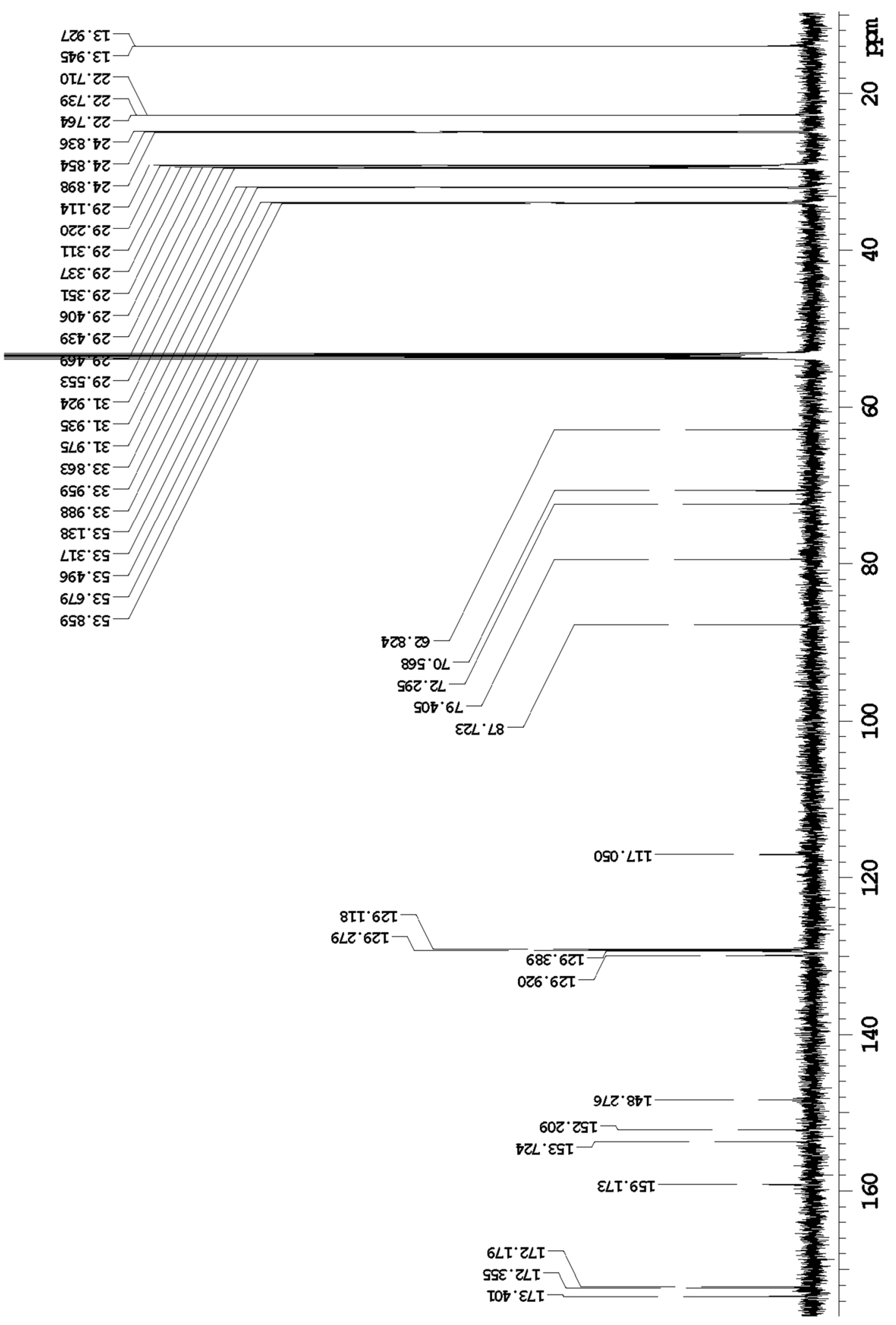

${ }^{13} \mathrm{C}\{1 \mathrm{H}\} \mathrm{NMR}\left(\mathrm{CD}_{2} \mathrm{Cl}_{2}, 600 \mathrm{MHz}\right)$ of $\mathbf{8 P h 5 C 1 0}$ 

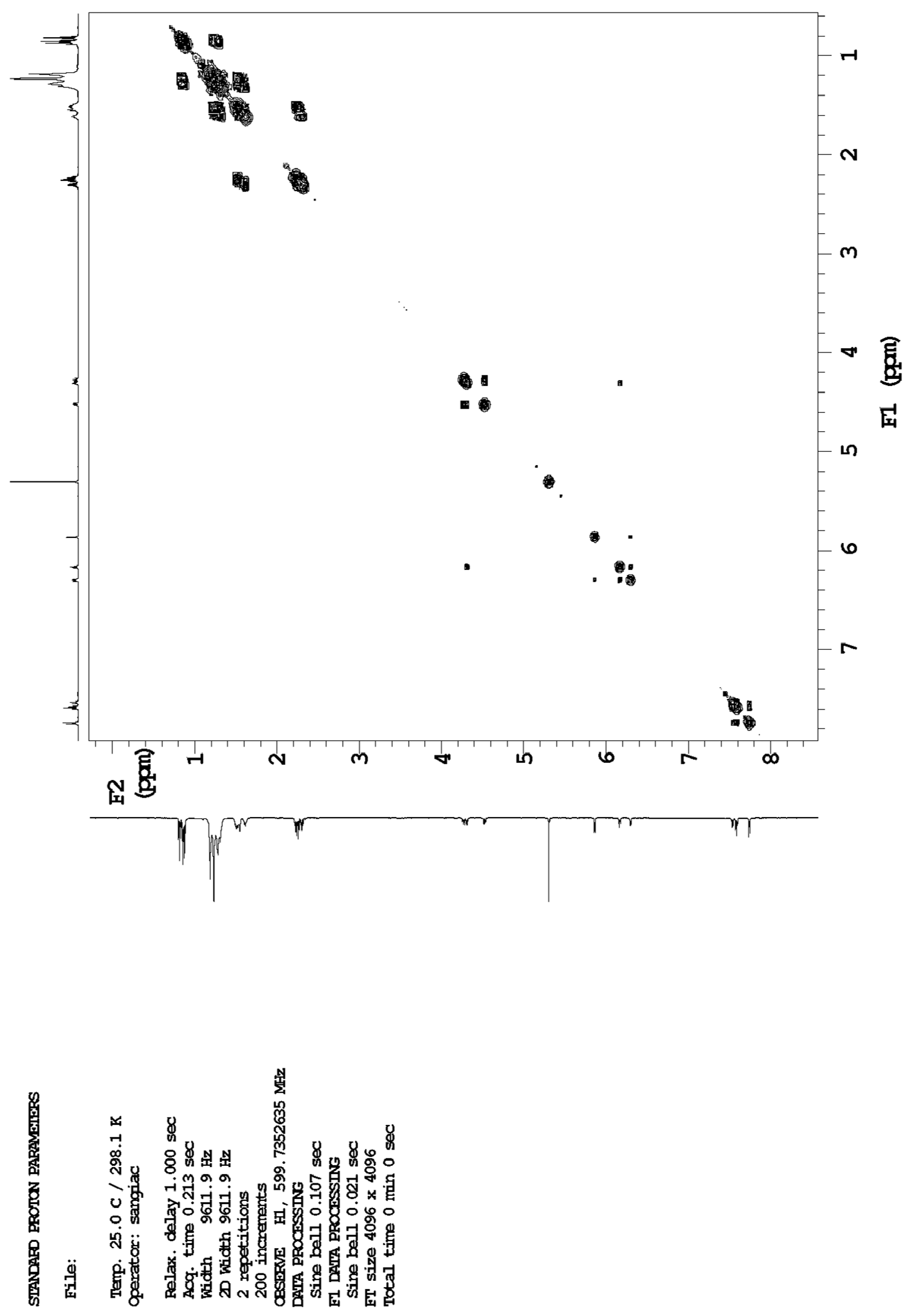

gCOSY spectrum $\left(\mathrm{CD}_{2} \mathrm{Cl}_{2}, 600 \mathrm{MHz}\right)$ of $\mathbf{8 P h 5 C 1 0}$ 


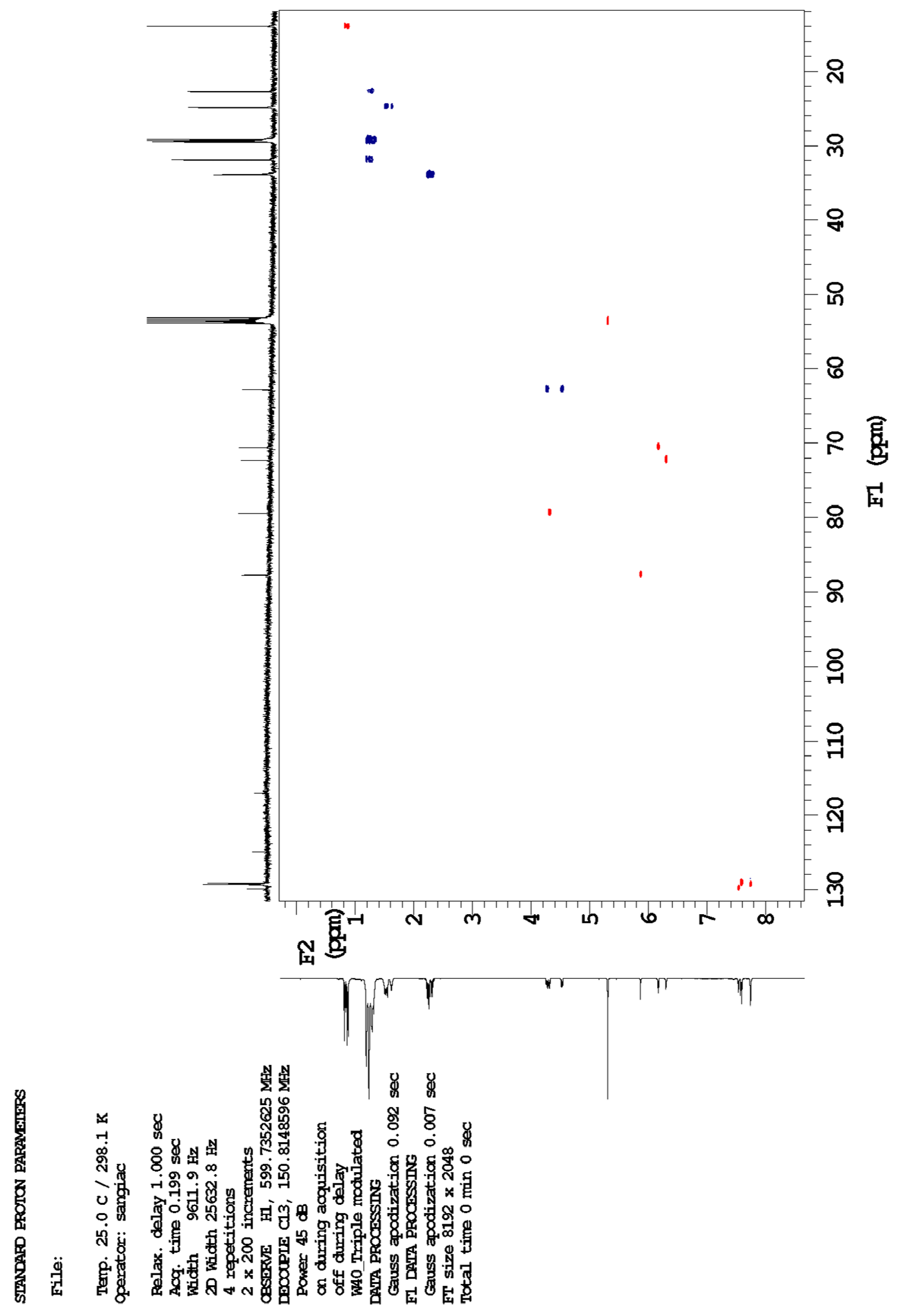

gHSQC spectrum $\left(\mathrm{CD}_{2} \mathrm{Cl}_{2}, 600 \mathrm{MHz}\right)$ of $\mathbf{8 P h 5 C 1 0}$ 


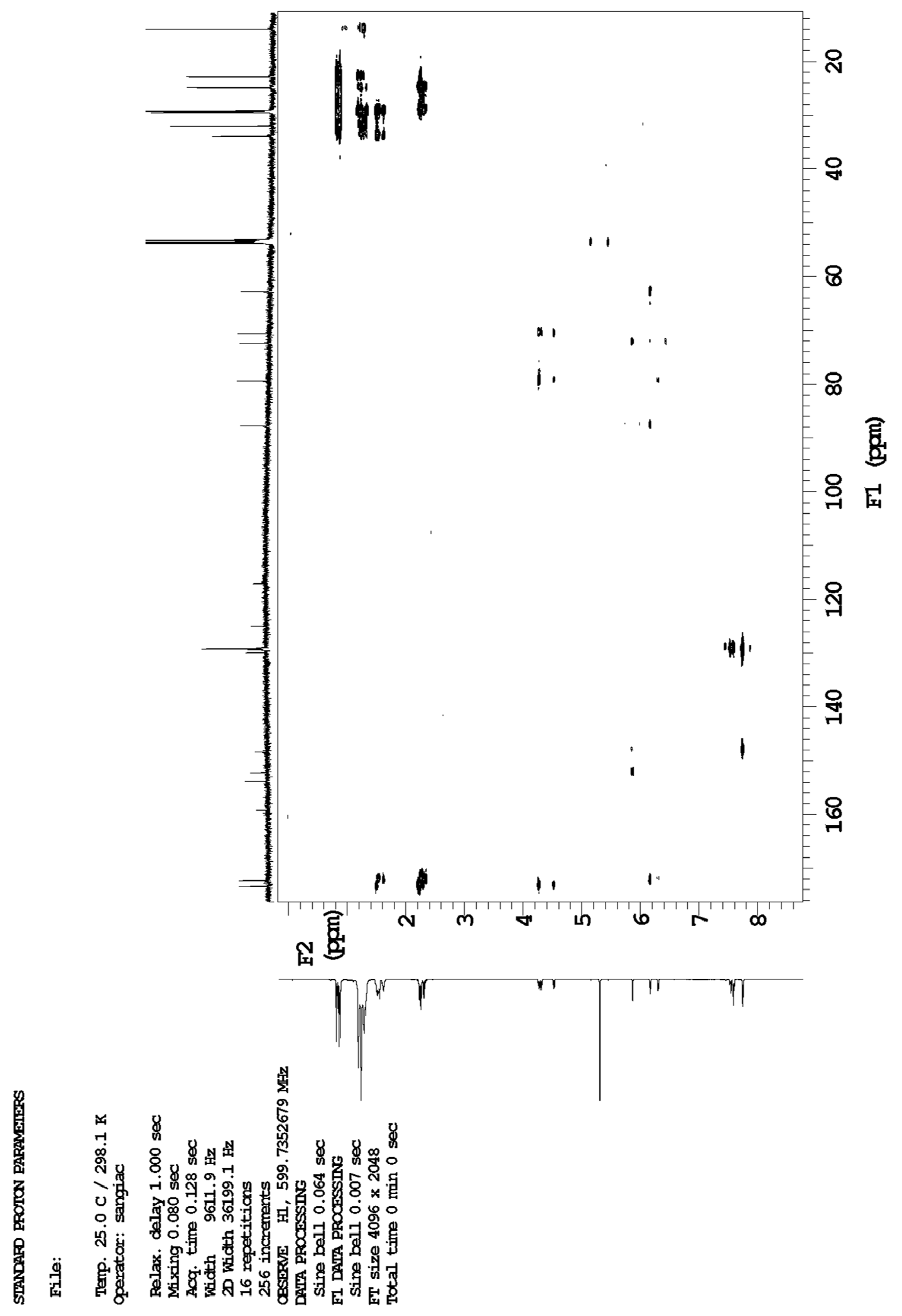

gHMBC spectrum $\left(\mathrm{CD}_{2} \mathrm{Cl}_{2}, 600 \mathrm{MHz}\right)$ of $\mathbf{8 P h 5 C 1 0}$ 


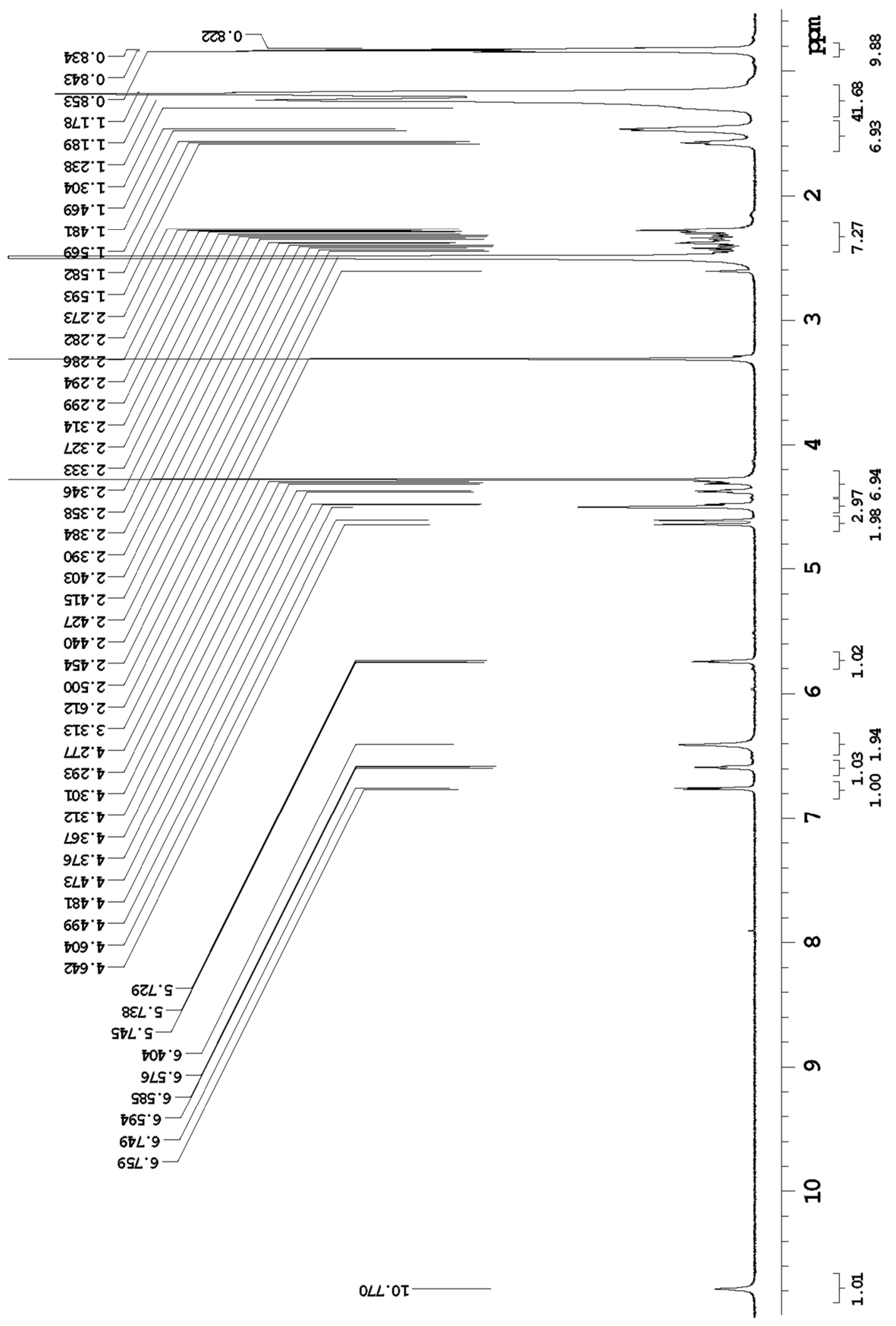

${ }^{1} \mathrm{H}-\mathrm{NMR}$ (dmso-d6, $600 \mathrm{MHz}$ ) of $\mathbf{8 F c 5 C 1 0}$ 


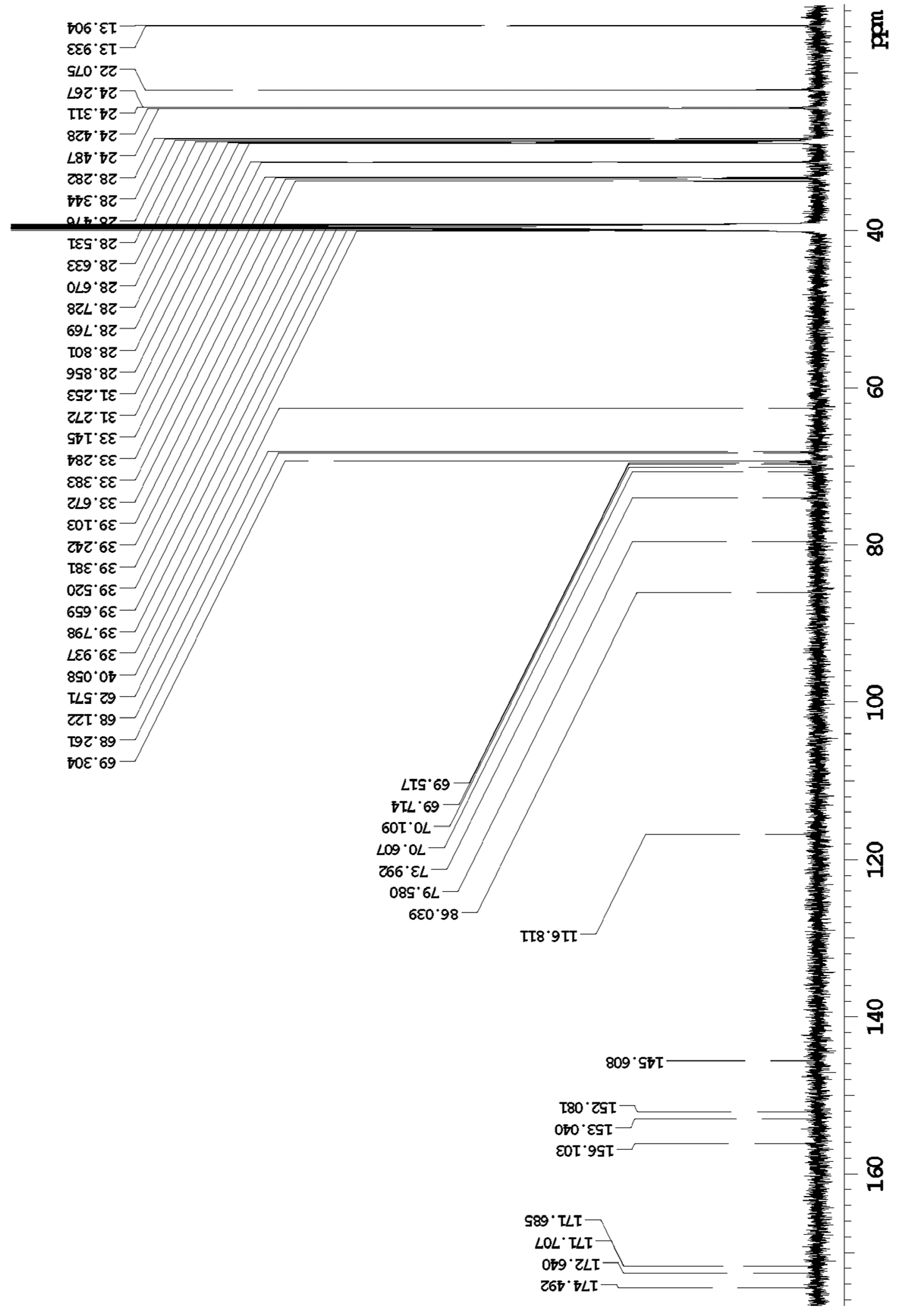

${ }^{13} \mathrm{C}\{1 \mathrm{H}\}$ NMR (dmso-d $6,600 \mathrm{MHz}$ ) of 8 Fc5C10 

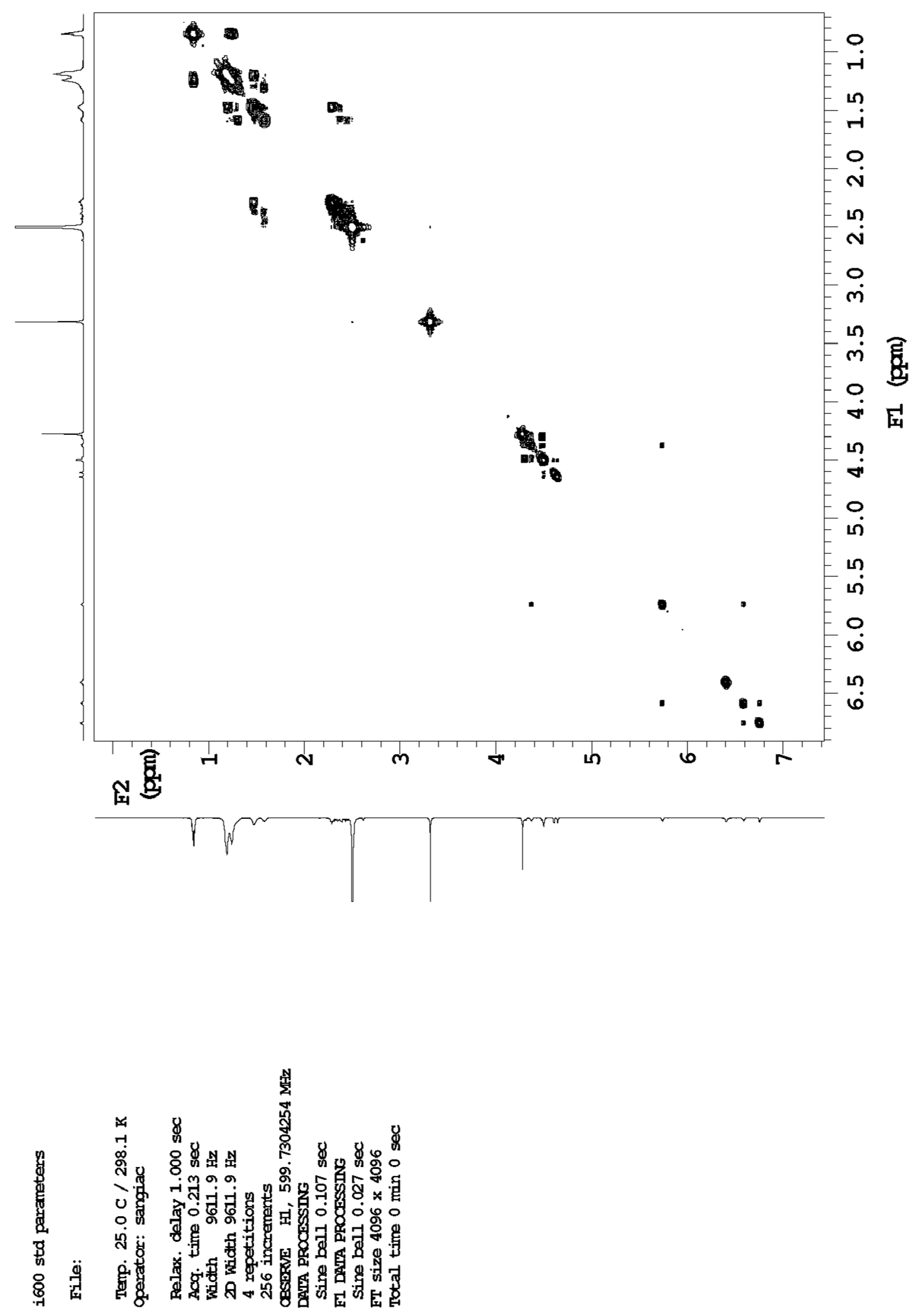

gCOSY spectrum (dmso-d $6,600 \mathrm{MHz}$ ) of $\mathbf{8 F c 5 C 1 0}$ 


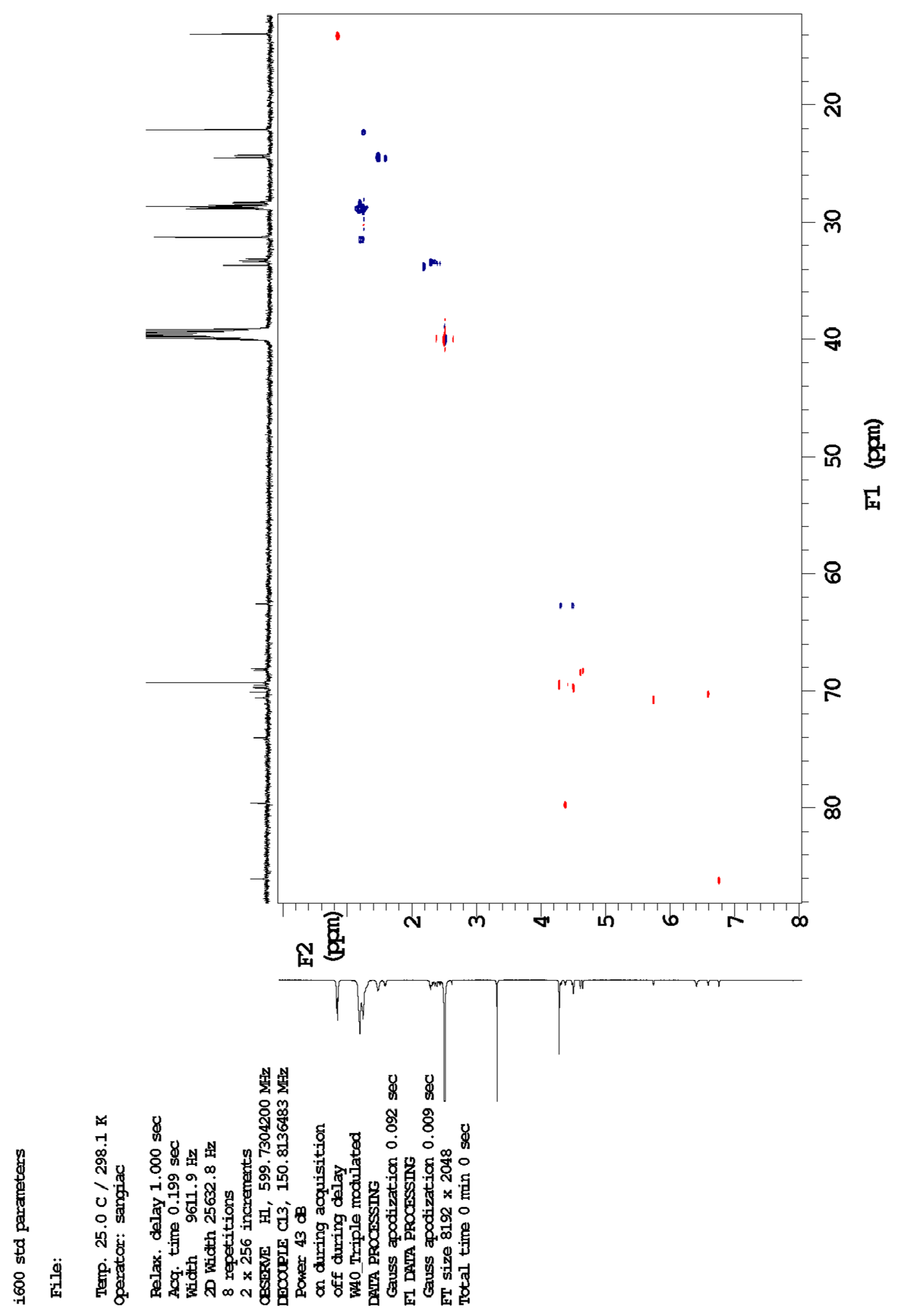

gHSQC spectrum (dmso-d6, $600 \mathrm{MHz}$ ) of 8 Fc5C10 


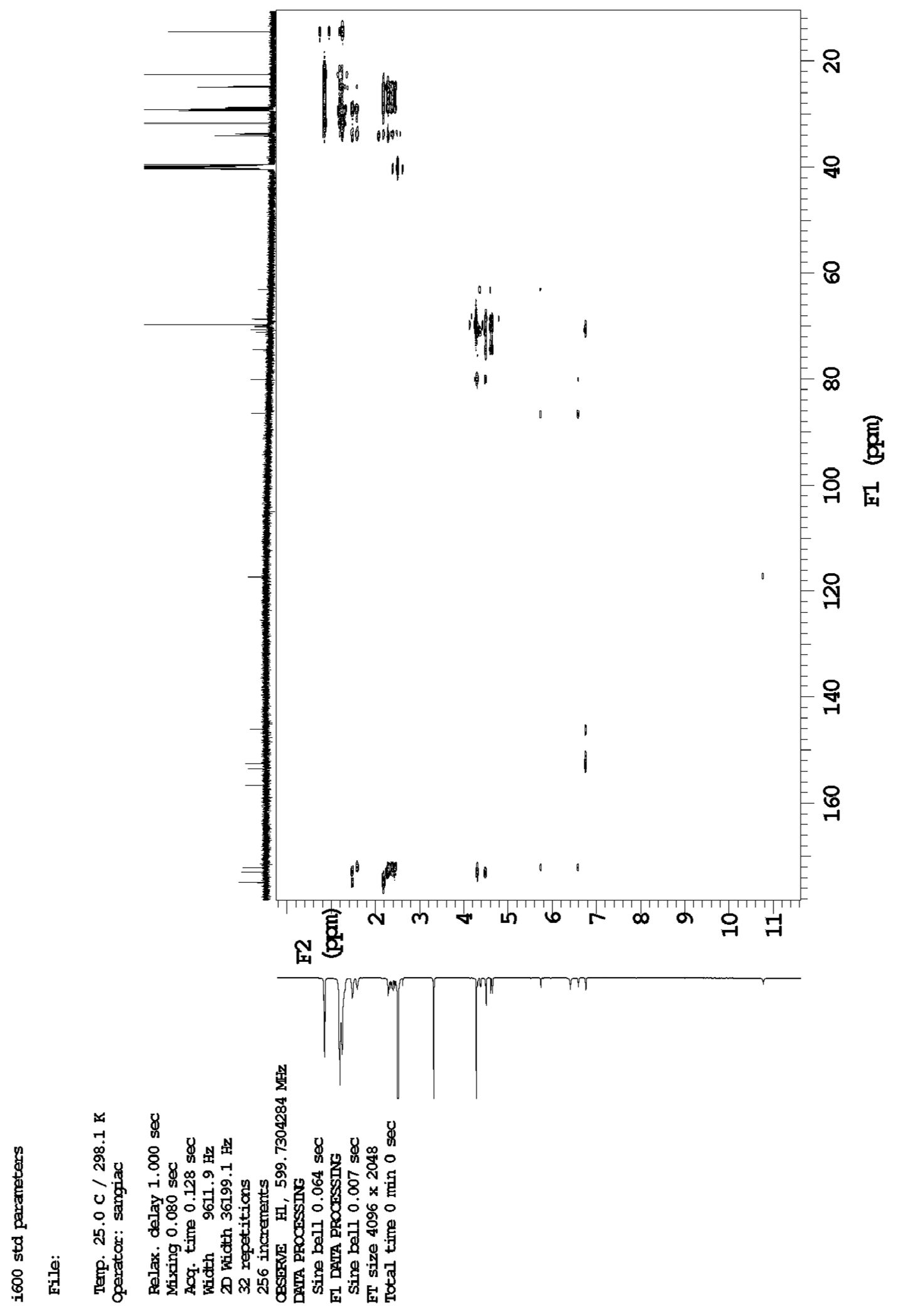

gHMBC spectrum (dmso-d6, $600 \mathrm{MHz}$ ) of $\mathbf{8 F c 5 C 1 0}$ 


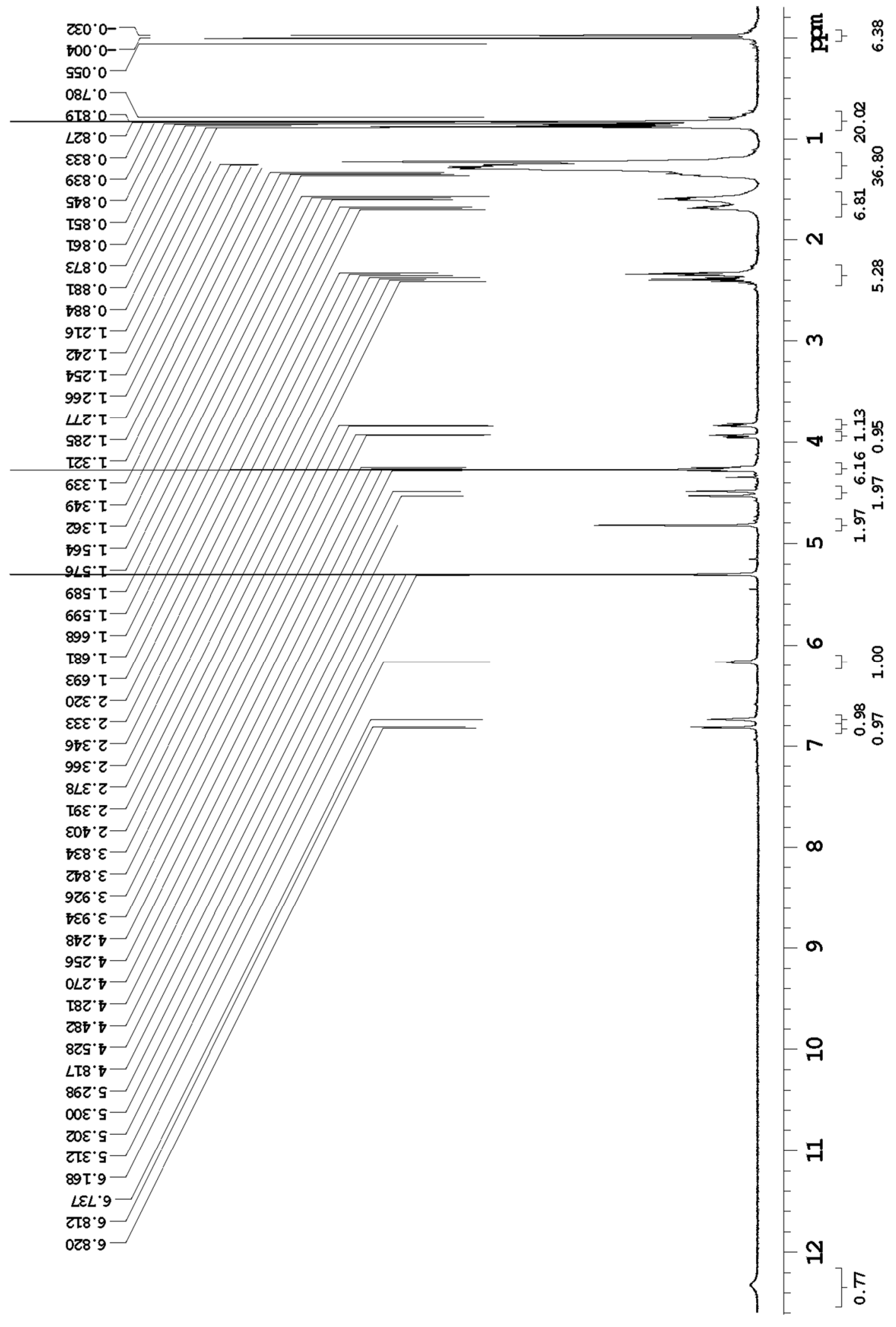

${ }^{1} \mathrm{H}-\mathrm{NMR}\left(\mathrm{CD}_{2} \mathrm{Cl}_{2}, 600 \mathrm{MHz}\right)$ of $\mathbf{8 F c 5 S i}$ 


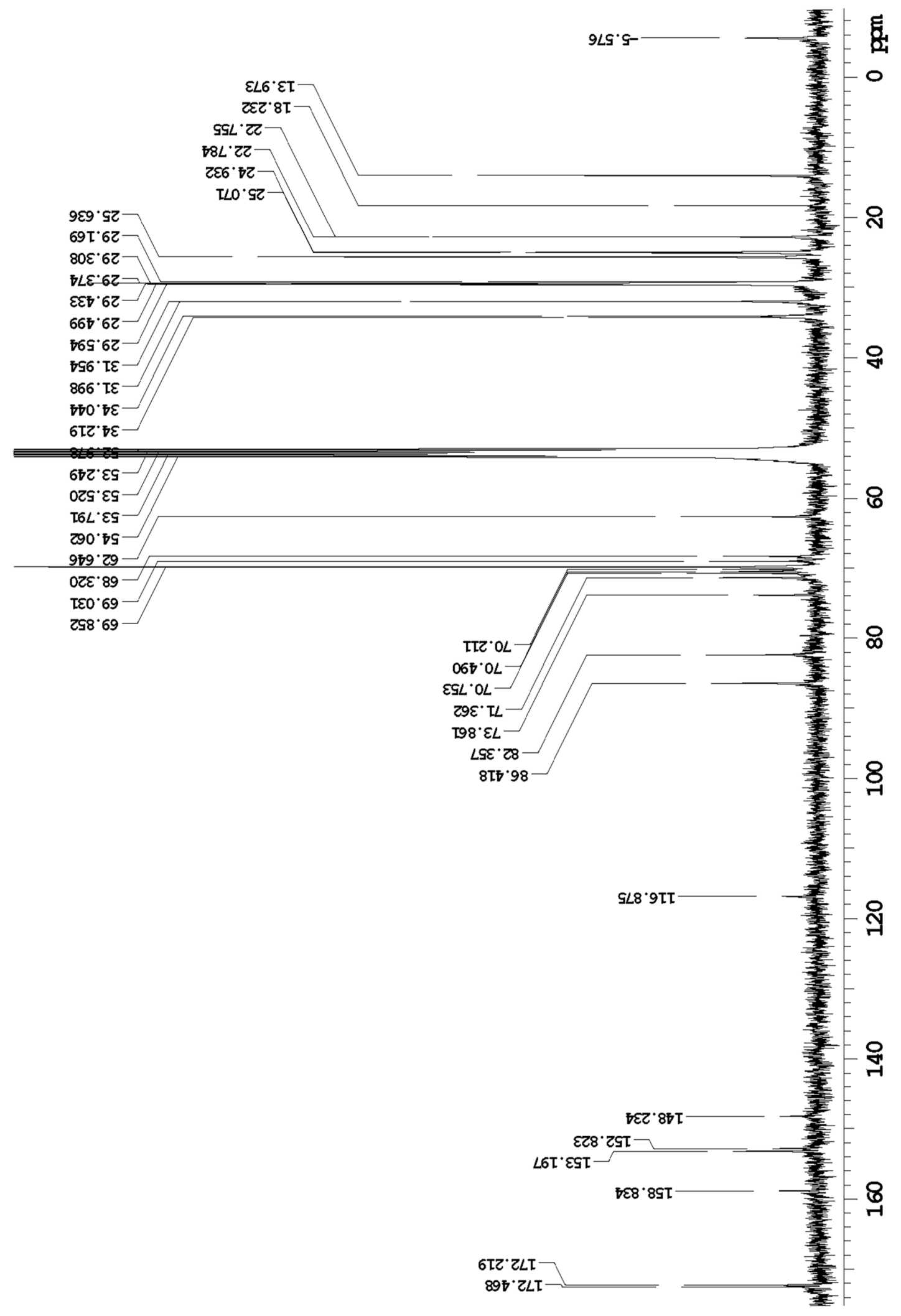

${ }^{13} \mathrm{C}\{1 \mathrm{H}\} \mathrm{NMR}\left(\mathrm{CD}_{2} \mathrm{Cl}_{2}, 600 \mathrm{MHz}\right)$ of $\mathbf{8 F} \mathbf{c 5 S i}$ 


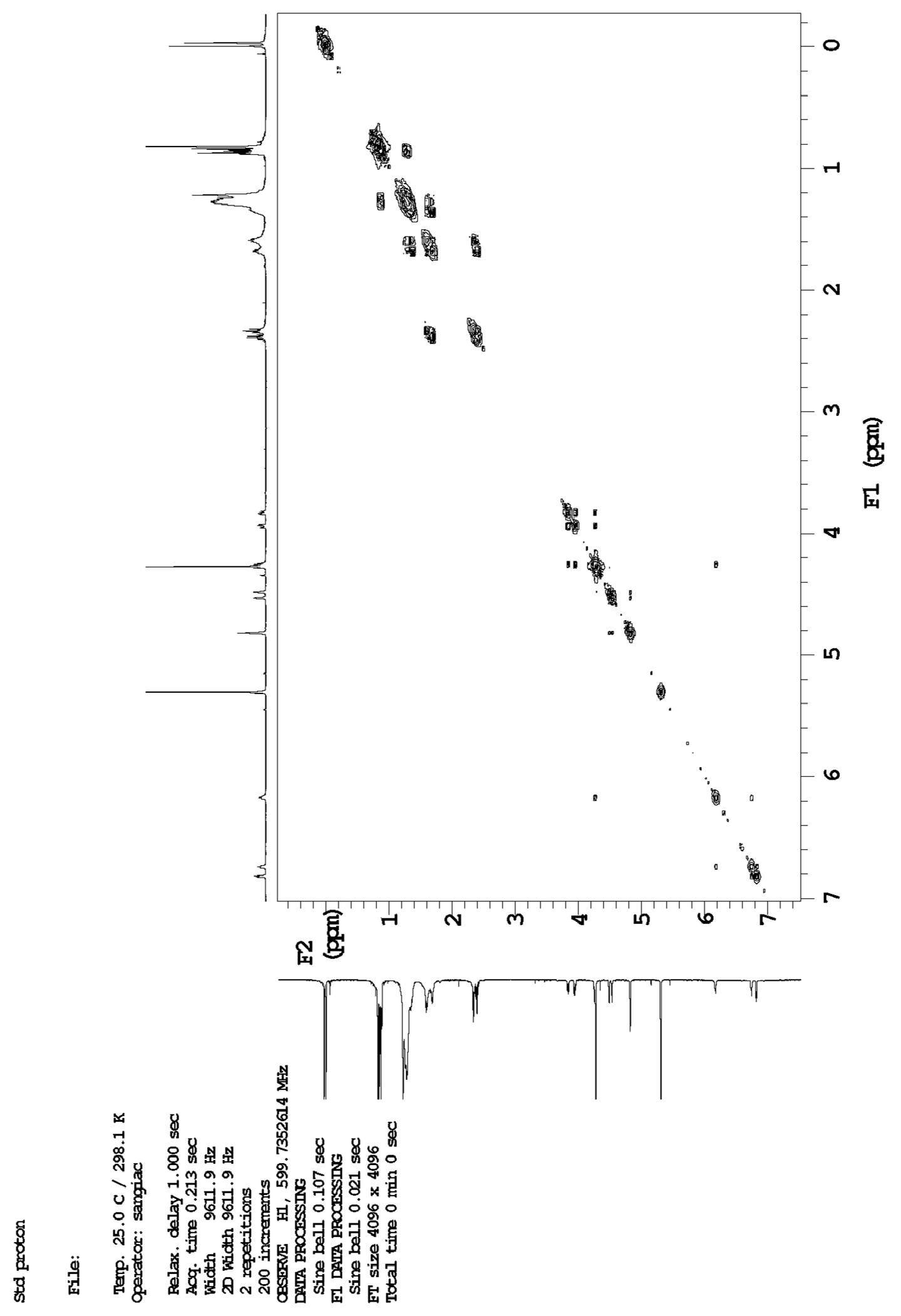

gCOSY spectrum $\left(\mathrm{CD}_{2} \mathrm{Cl}_{2}, 600 \mathrm{MHz}\right)$ of $\mathbf{8 F} \mathbf{c 5 S i}$ 


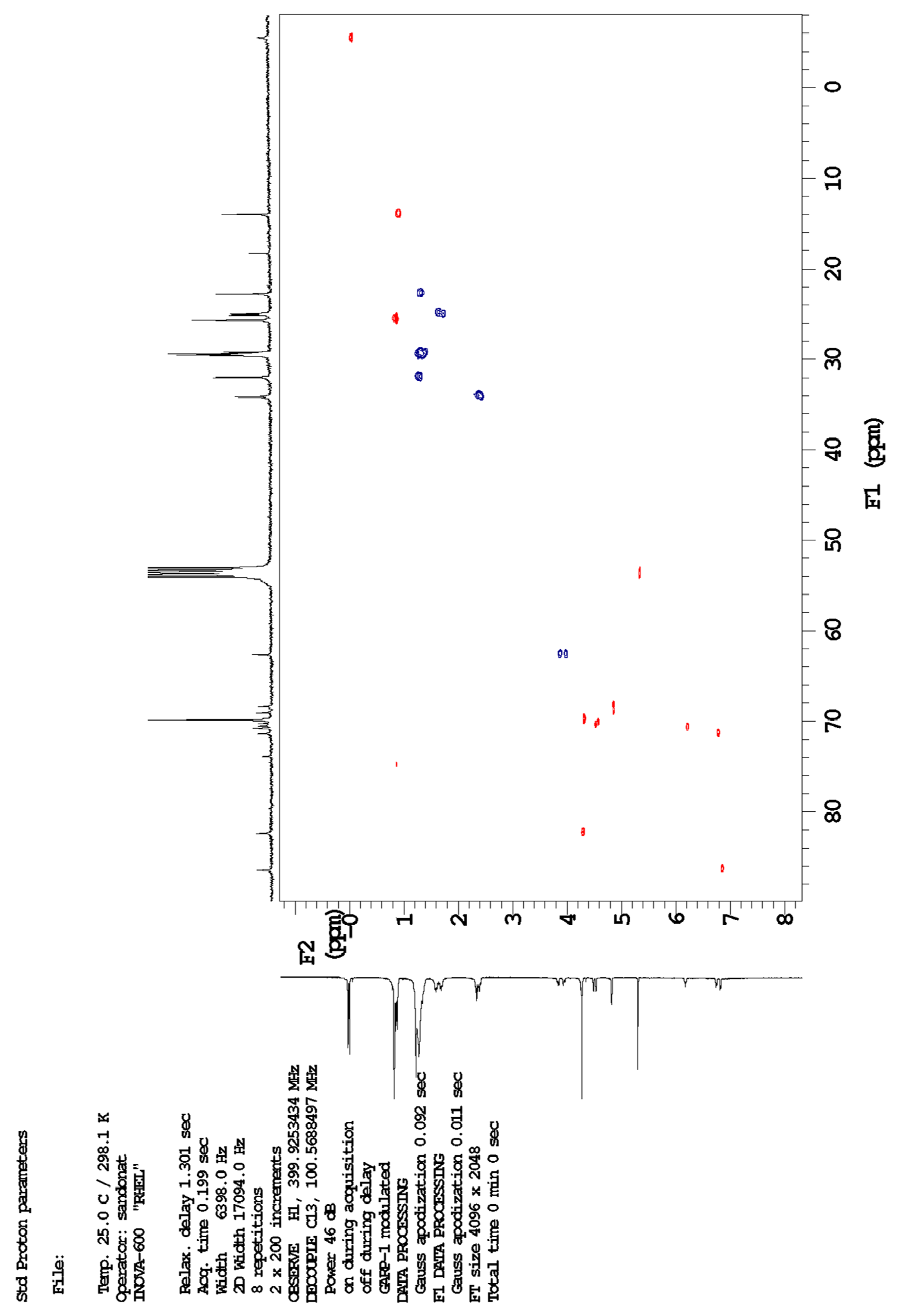

gHSQC spectrum $\left(\mathrm{CD}_{2} \mathrm{Cl}_{2}, 600 \mathrm{MHz}\right)$ of $\mathbf{8 F} \mathbf{c 5 S i}$ 


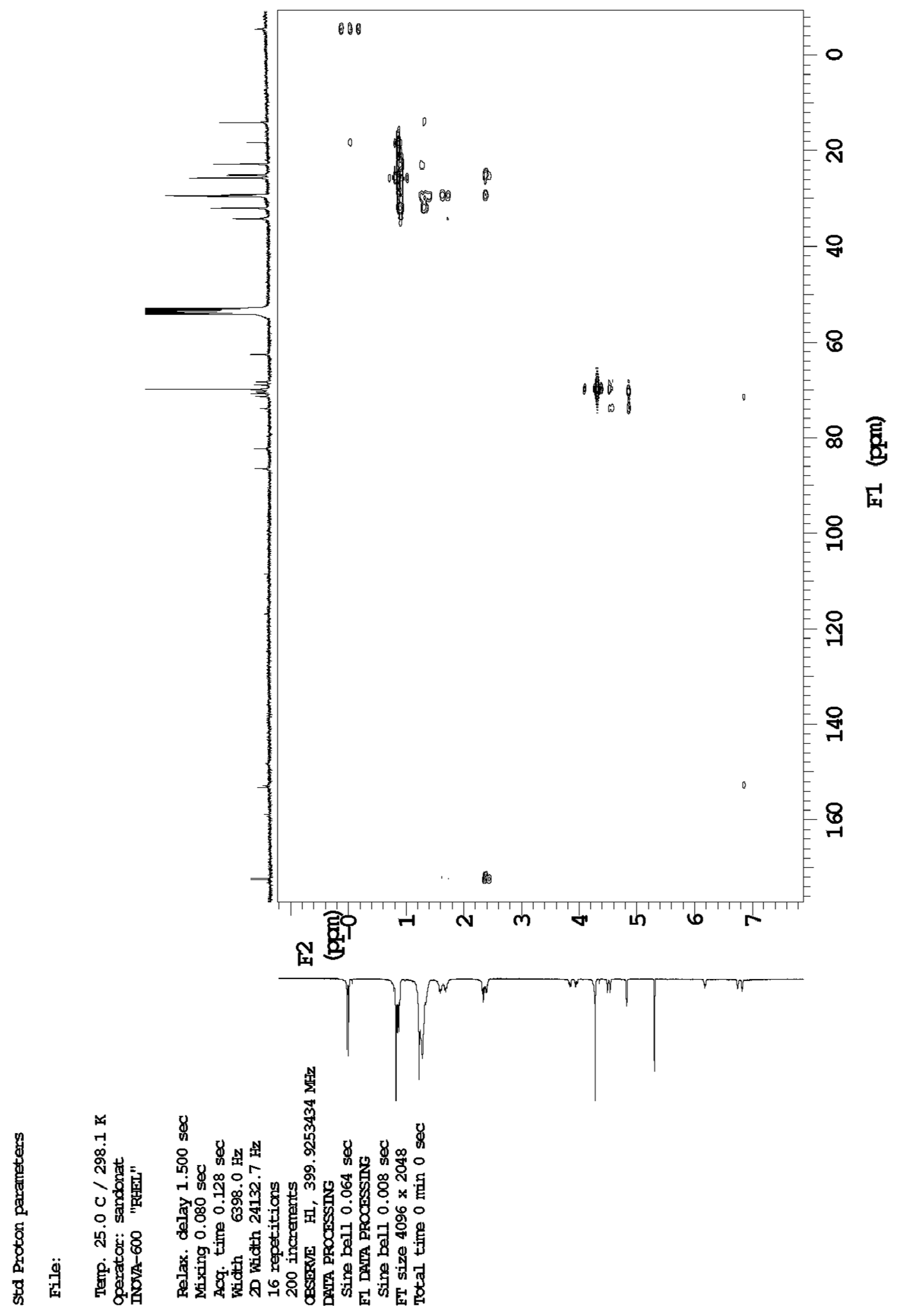

gHMBC spectrum $\left(\mathrm{CD}_{2} \mathrm{Cl}_{2}, 600 \mathrm{MHz}\right)$ of $\mathbf{8 F} \mathbf{5 S i}$ 


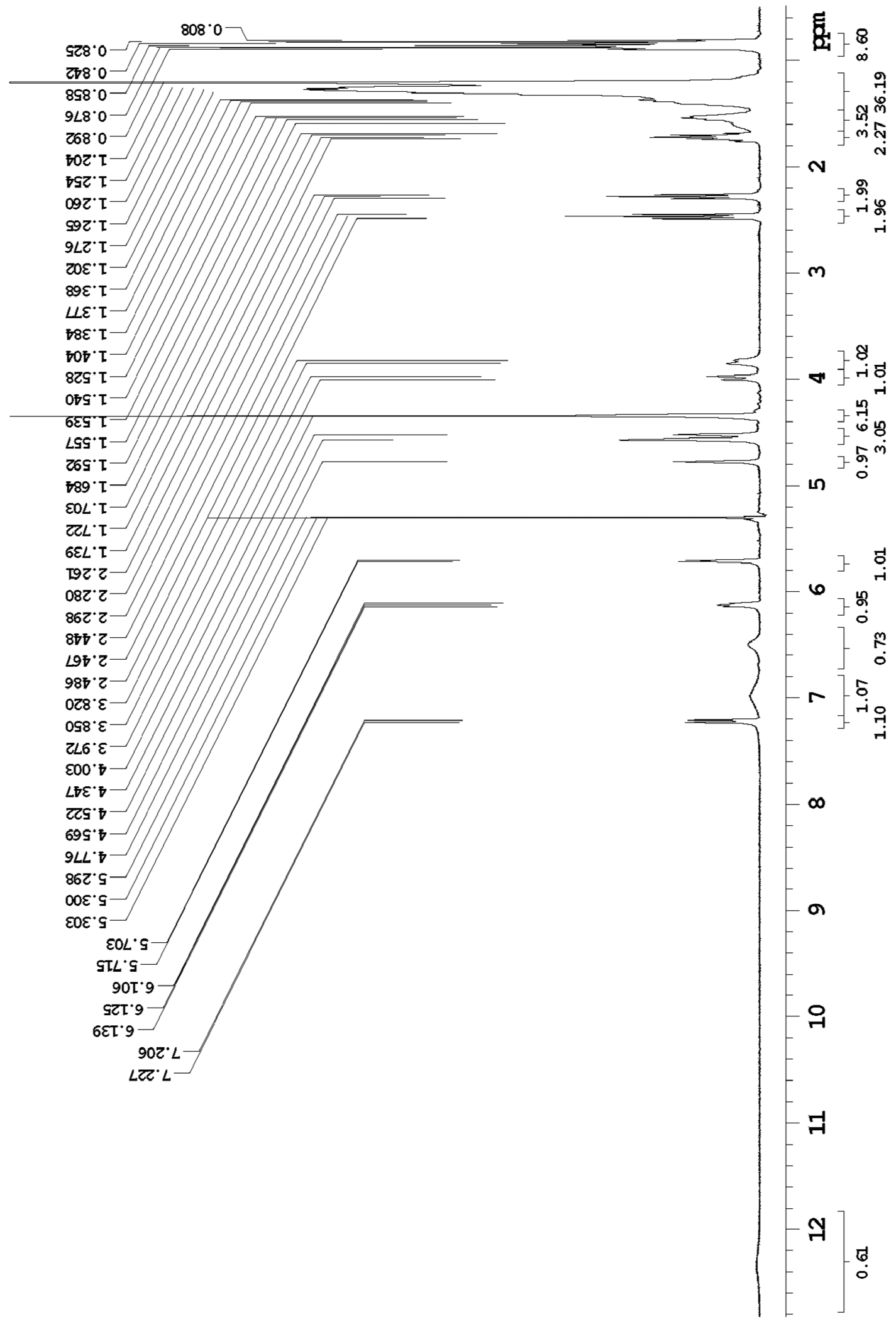

${ }^{1} \mathrm{H}-\mathrm{NMR}\left(\mathrm{CD}_{2} \mathrm{Cl}_{2}, 600 \mathrm{MHz}\right)$ of $\mathbf{8 F} \mathbf{c 5 O H}$ 


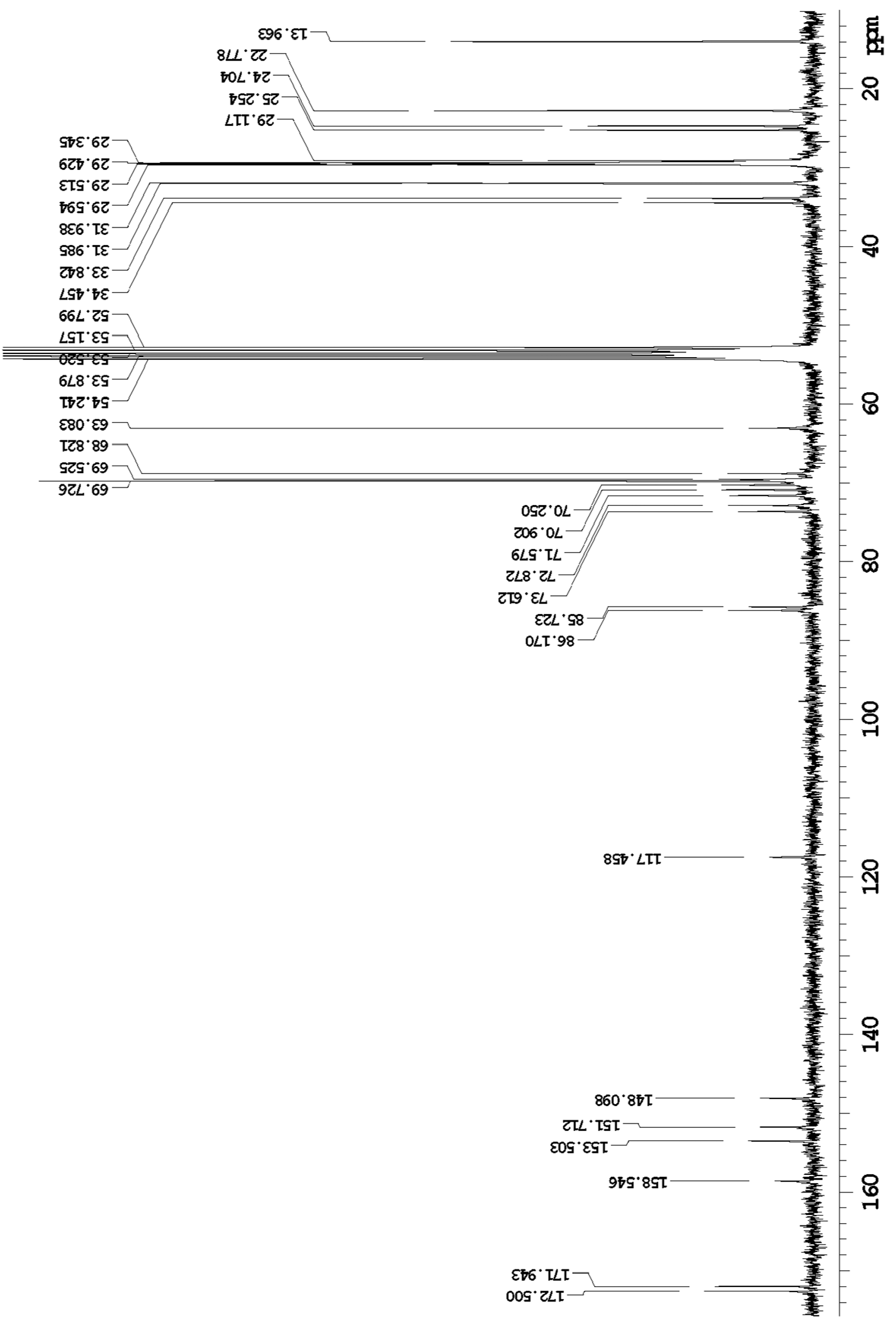

${ }^{13} \mathrm{C}\{1 \mathrm{H}\} \mathrm{NMR}\left(\mathrm{CD}_{2} \mathrm{Cl}_{2}, 600 \mathrm{MHz}\right)$ of $\mathbf{8 F c 5 O H}$. 


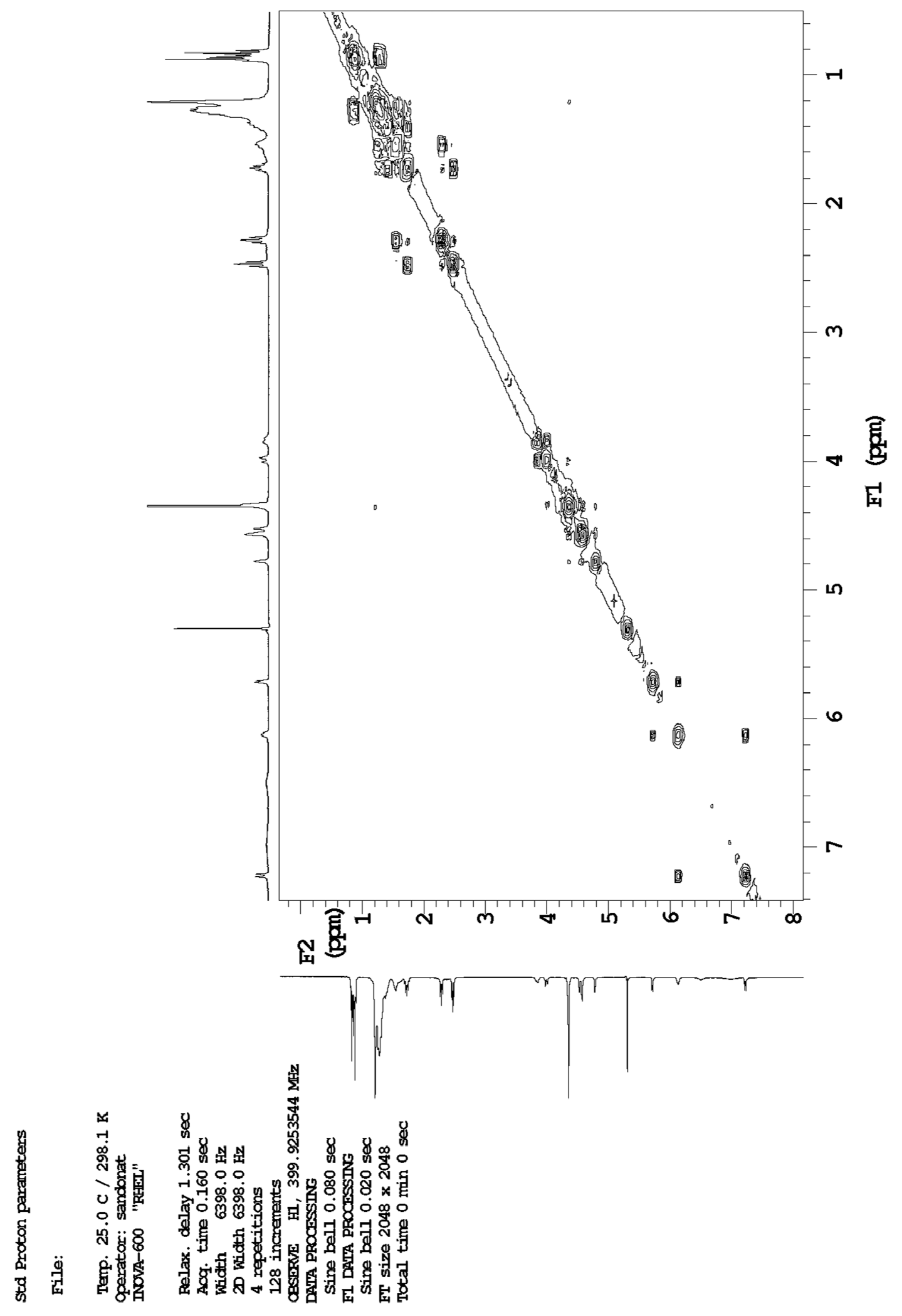

gCOSY spectrum $\left(\mathrm{CD}_{2} \mathrm{Cl}_{2}, 600 \mathrm{MHz}\right)$ of $\mathbf{8 F} \mathbf{c 5 O H}$ 


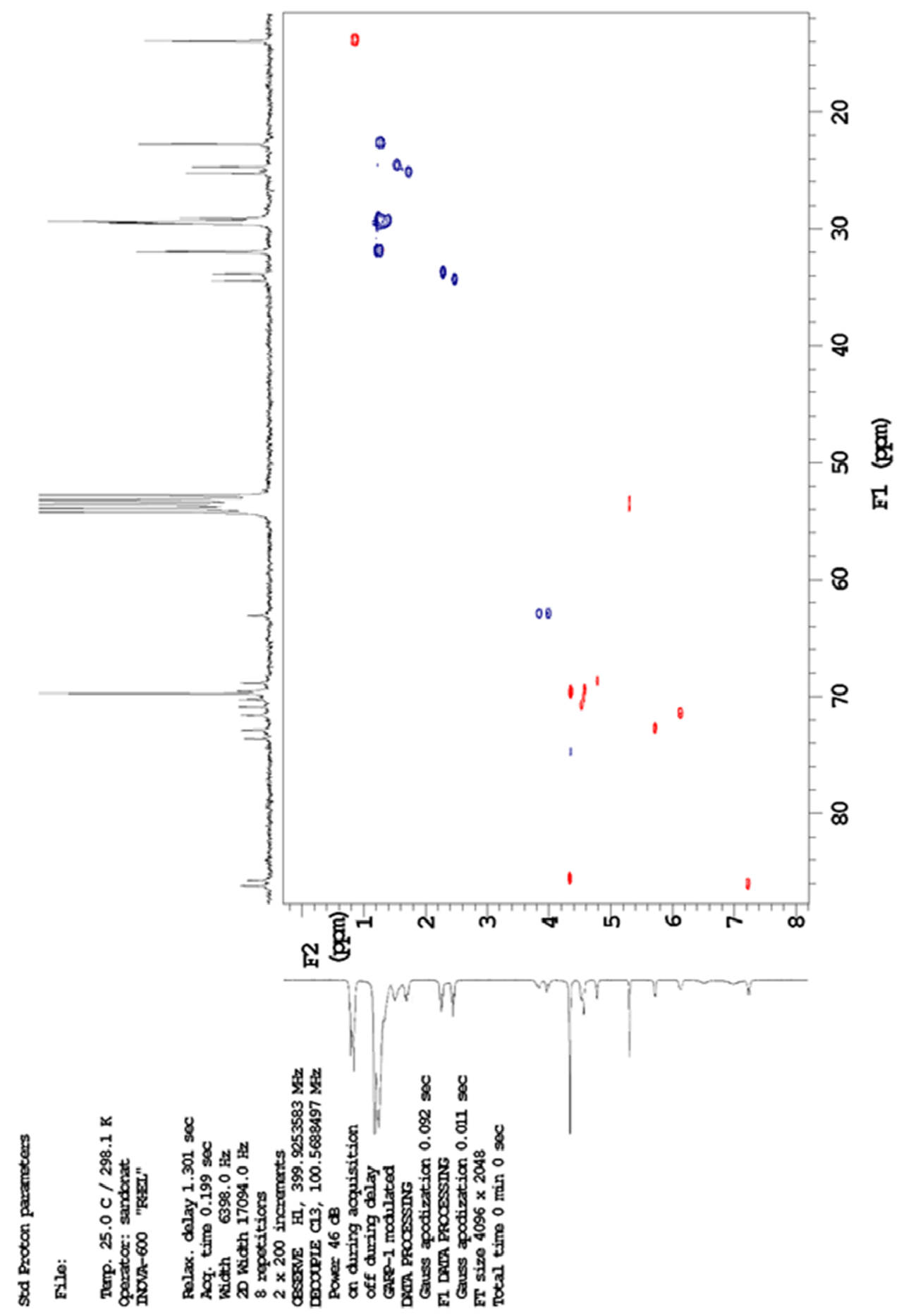

gHSQC spectrum $\left(\mathrm{CD}_{2} \mathrm{Cl}_{2}, 600 \mathrm{MHz}\right)$ of $\mathbf{8 F} \mathbf{5 0 H}$ 


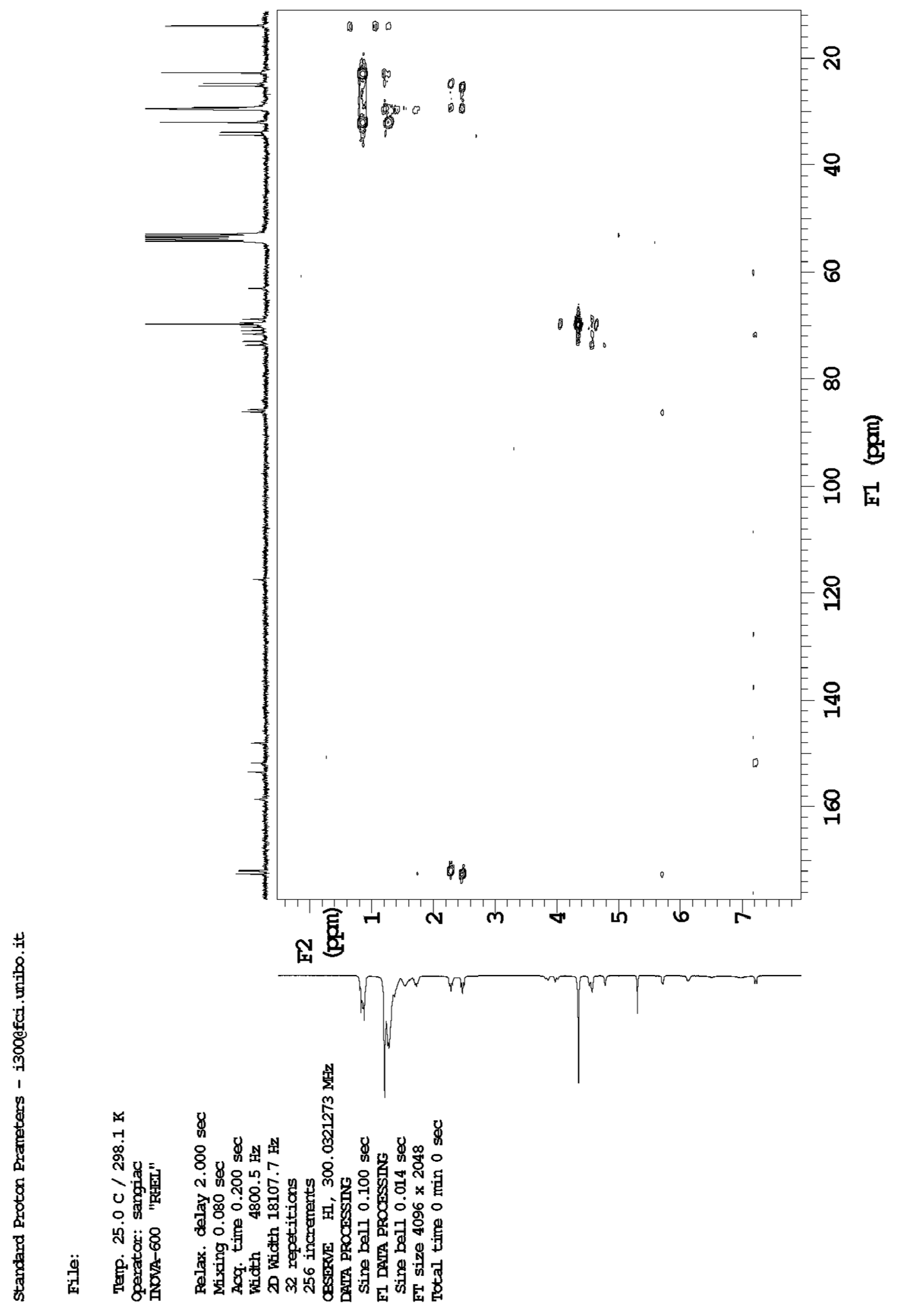

gHMBC spectrum $\left(\mathrm{CD}_{2} \mathrm{Cl}_{2}, 600 \mathrm{MHz}\right)$ of $\mathbf{8 F} \mathbf{c 5 O H}$ 


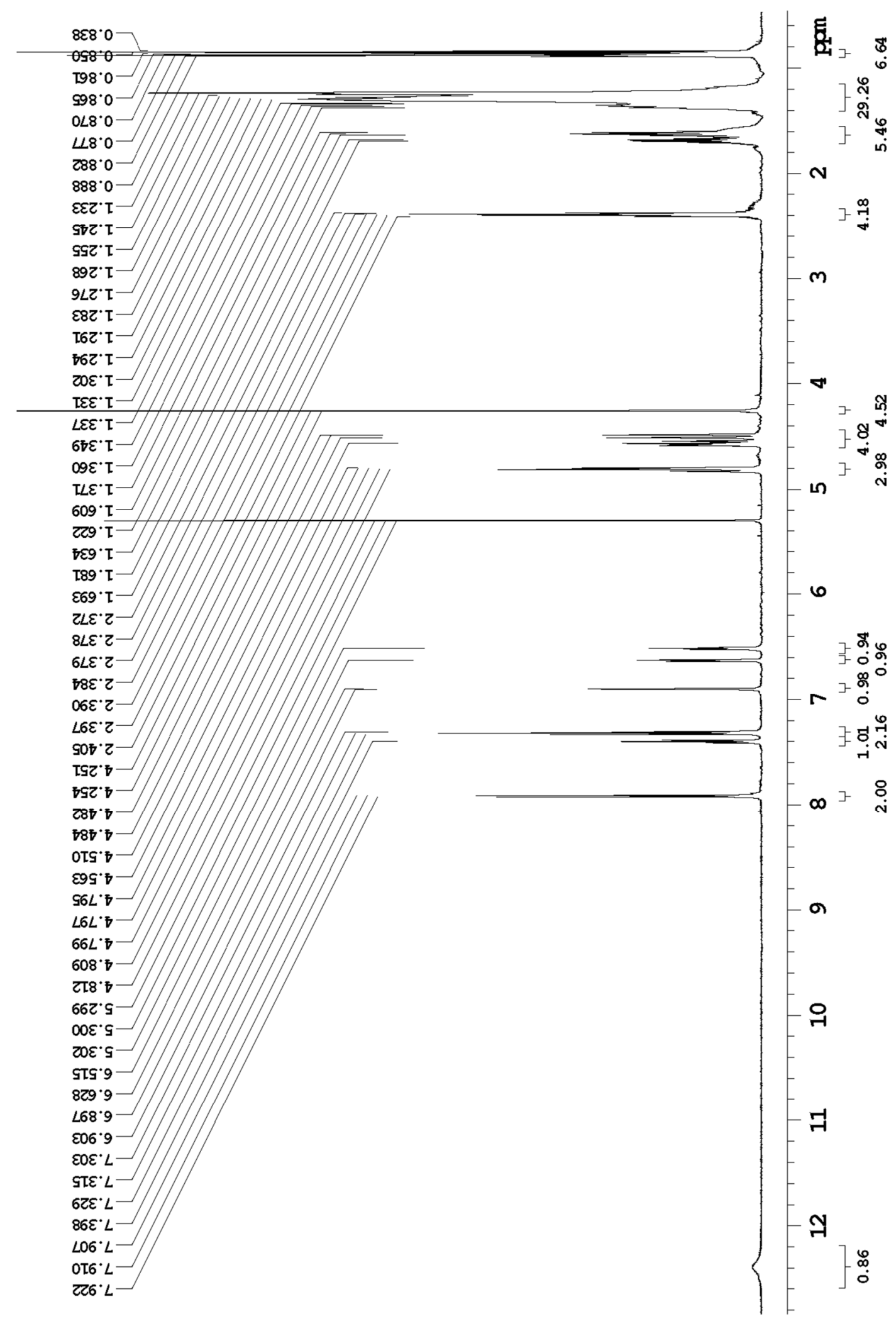

${ }^{1} \mathrm{H}-\mathrm{NMR}\left(\mathrm{CD}_{2} \mathrm{Cl}_{2}, 600 \mathrm{MHz}\right)$ of $\mathbf{8 F} \mathbf{5} \mathbf{P h}$ 


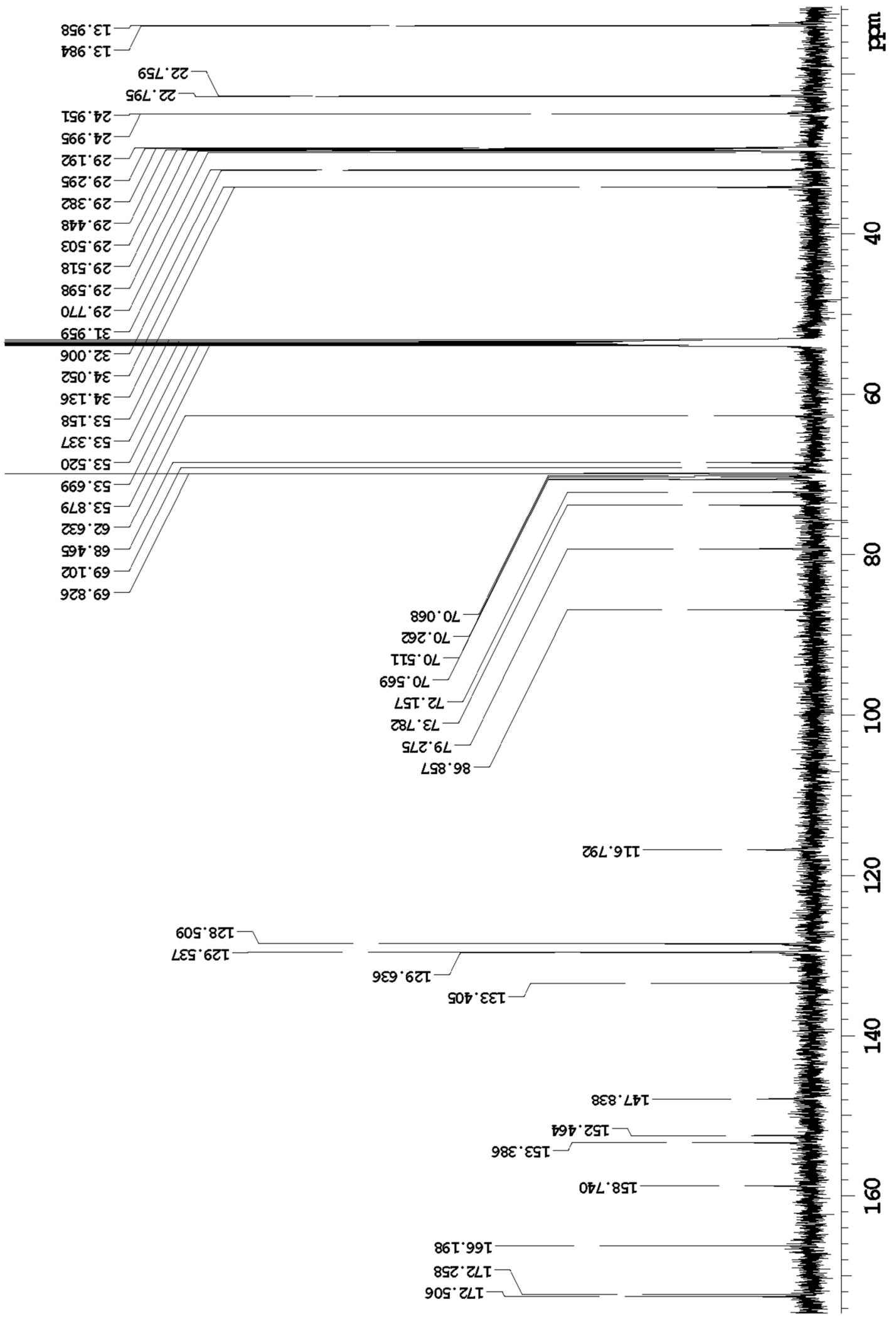

${ }^{13} \mathrm{C}\{1 \mathrm{H}\} \mathrm{NMR}\left(\mathrm{CD}_{2} \mathrm{Cl}_{2}, 600 \mathrm{MHz}\right)$ of $\mathbf{8 F} 5 \mathbf{P P h}$. 


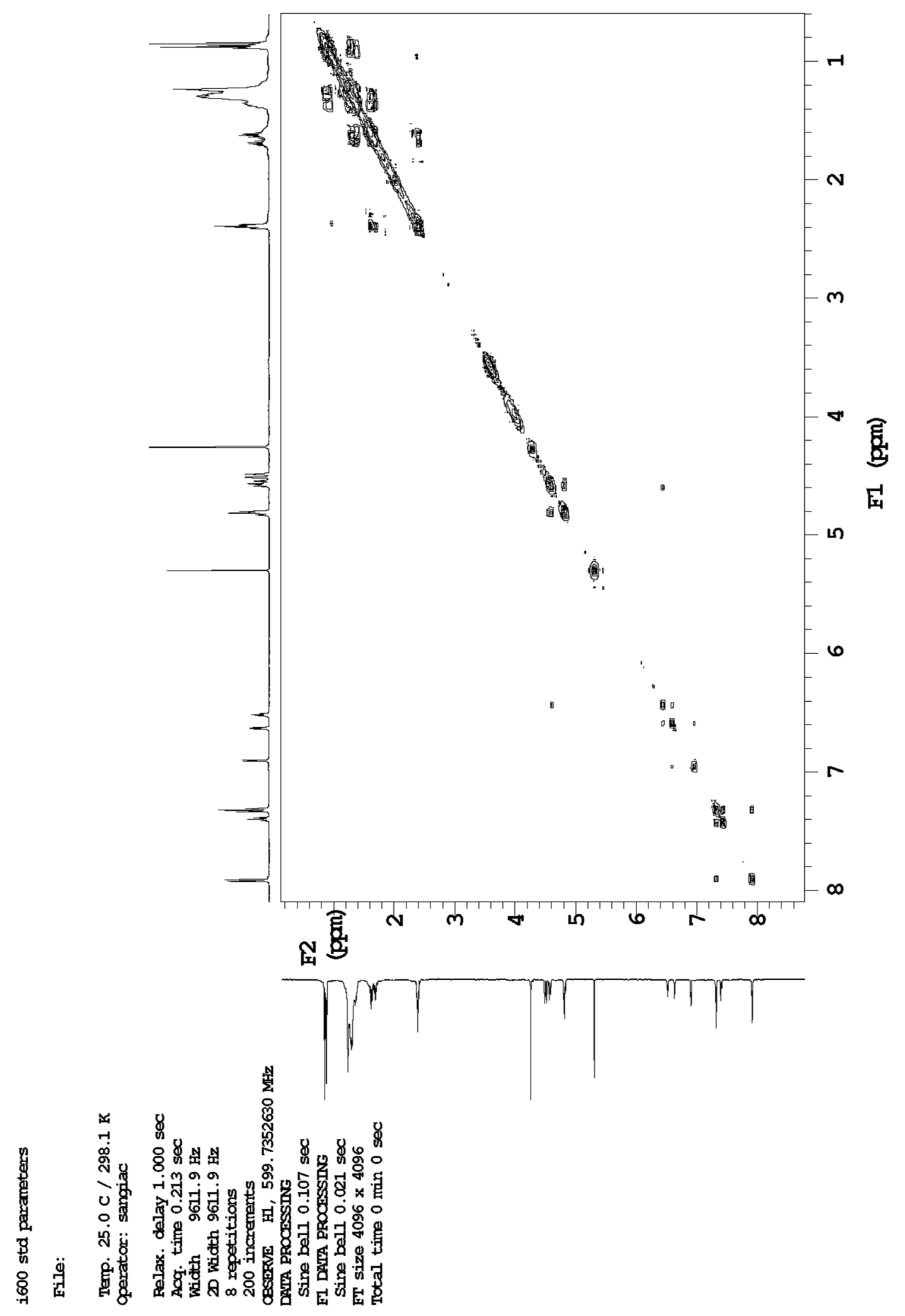

gCOSY spectrum $\left(\mathrm{CD}_{2} \mathrm{Cl}_{2}, 600 \mathrm{MHz}\right)$ of $\mathbf{8 F} \mathbf{F 5} \mathbf{P h}$ 


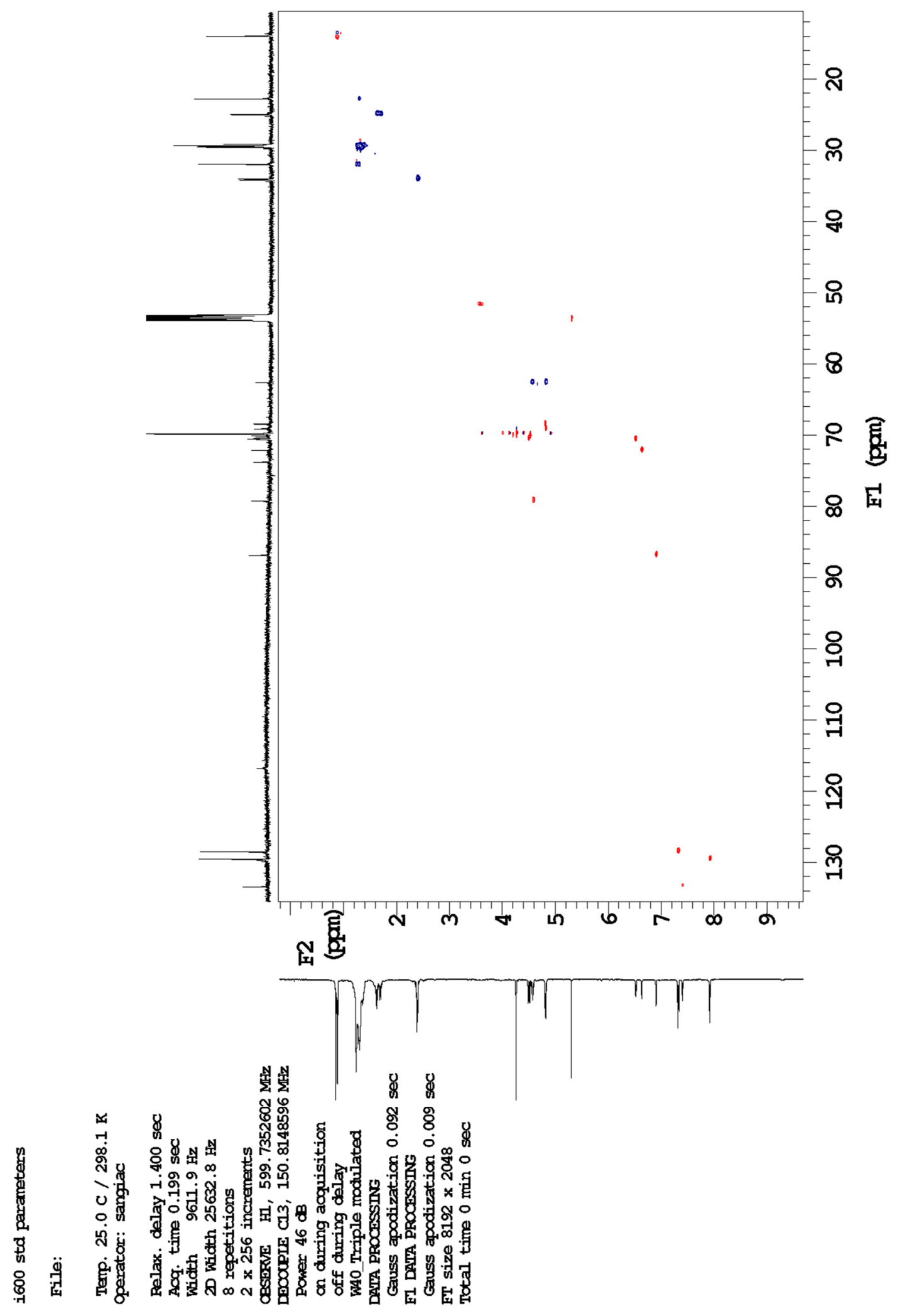

gHSQC spectrum $\left(\mathrm{CD}_{2} \mathrm{Cl}_{2}, 600 \mathrm{MHz}\right)$ of $\mathbf{8 F} \mathbf{c 5 P h}$ 


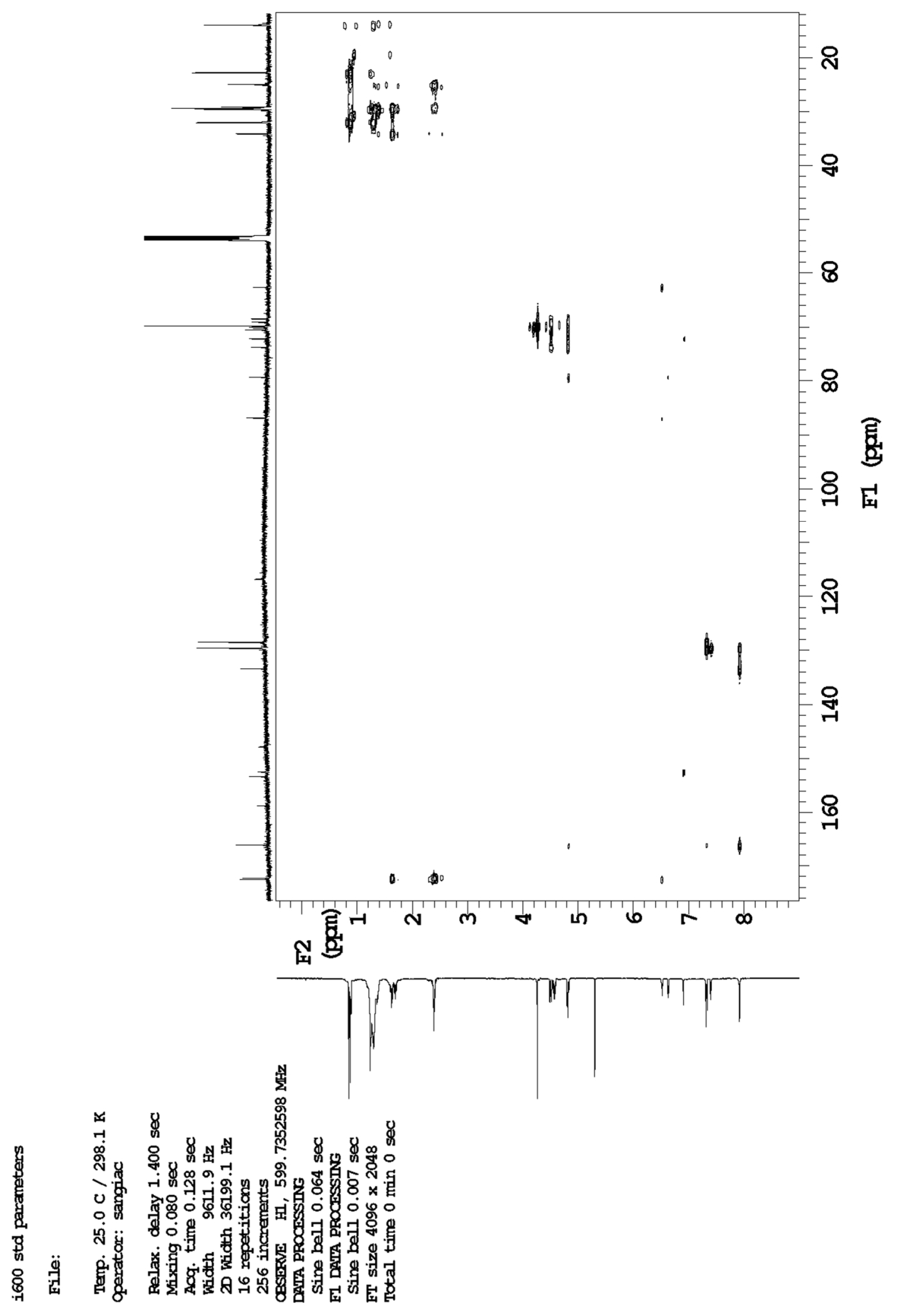

gHMBC spectrum $\left(\mathrm{CD}_{2} \mathrm{Cl}_{2}, 600 \mathrm{MHz}\right)$ of $\mathbf{8 F c 5 P}$ 


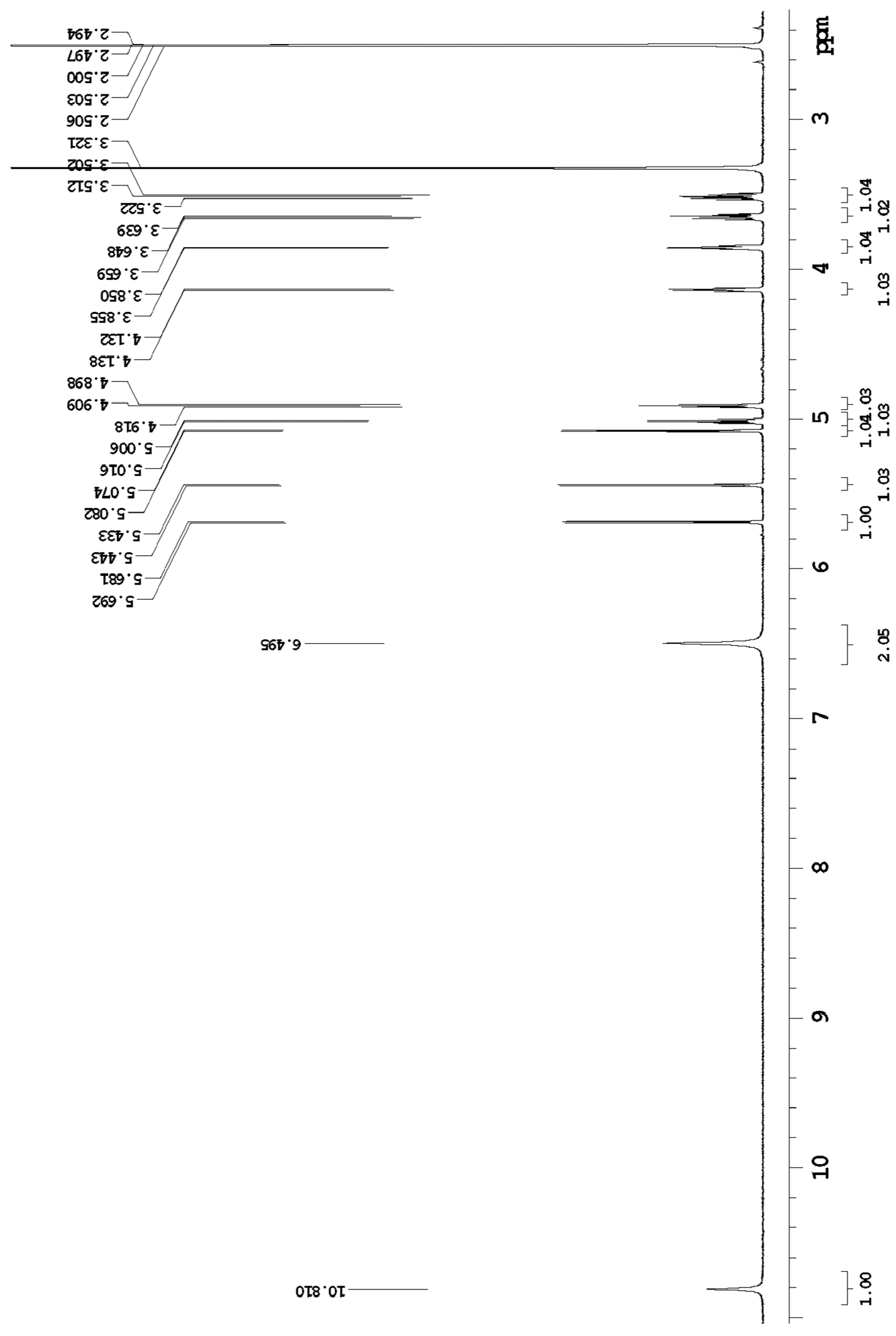

${ }^{1} \mathrm{H}-\mathrm{NMR}$ (dmso-d6, $600 \mathrm{MHz}$ ) of 9 


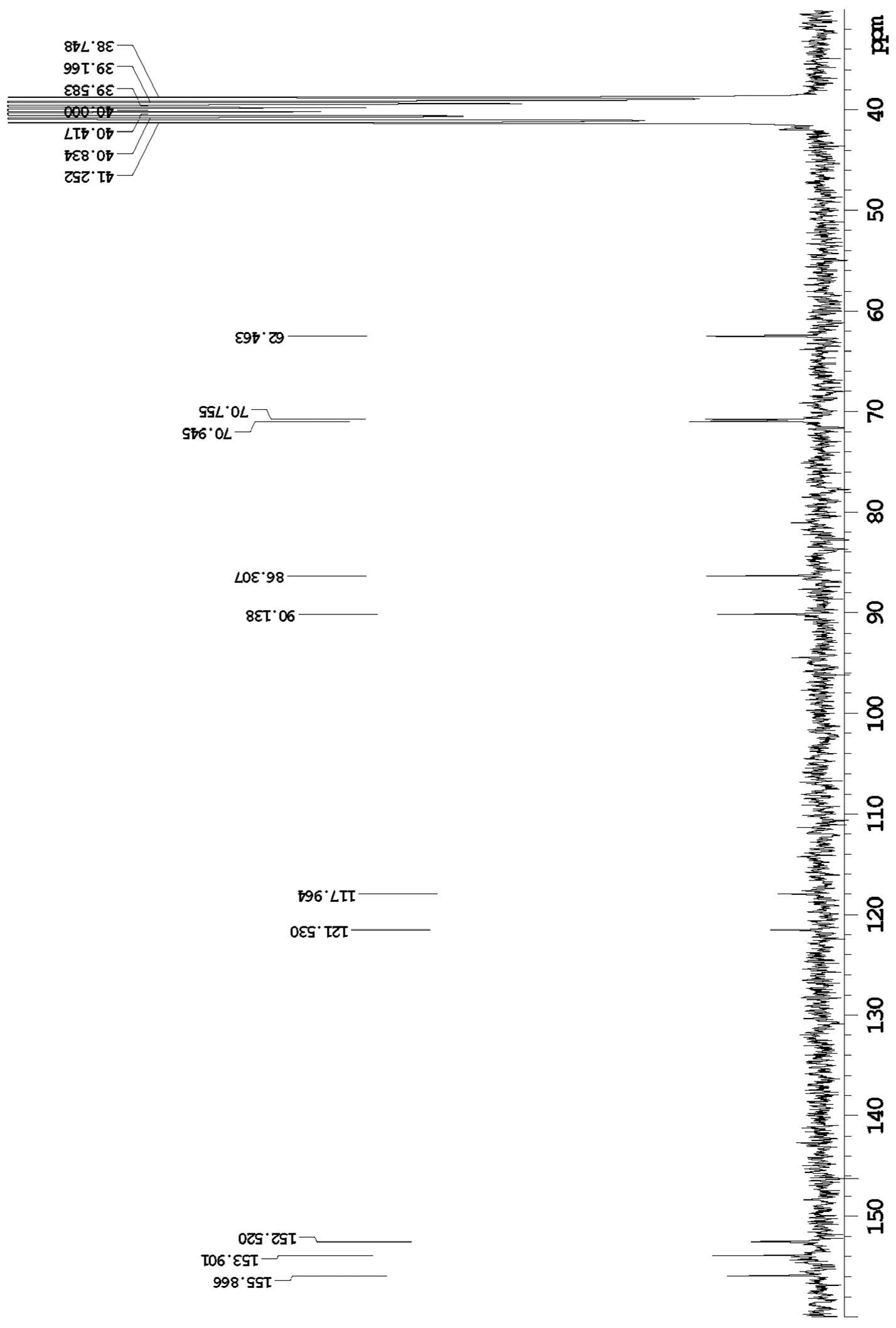

${ }^{13} \mathrm{C}\{1 \mathrm{H}\}$ NMR (dmso-d6, $\left.75 \mathrm{MHz}\right)$ of 9 


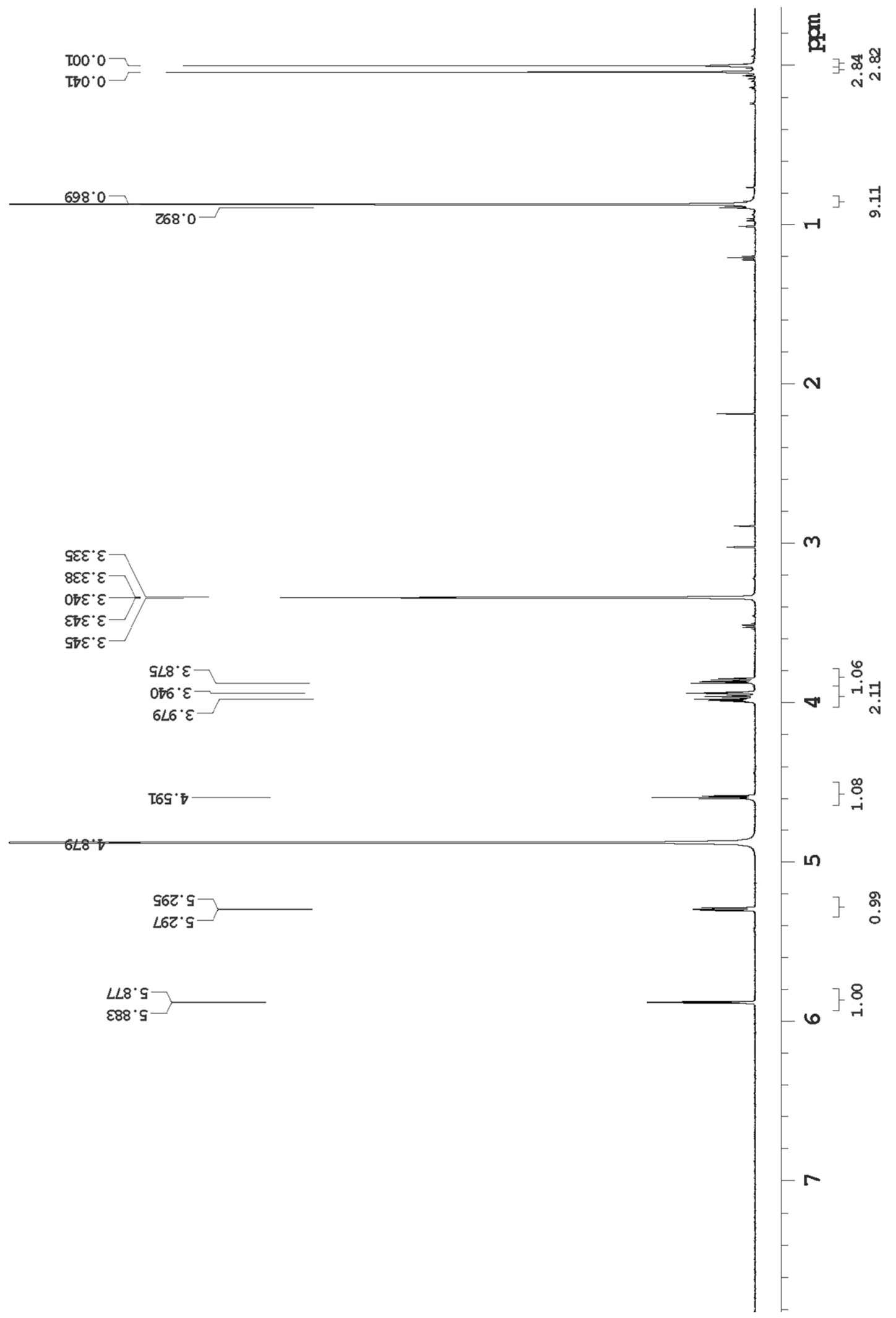

${ }^{1} \mathrm{H}-\mathrm{NMR}\left(\mathrm{CD}_{3} \mathrm{OD}, 600 \mathrm{MHz}\right)$ of 10 


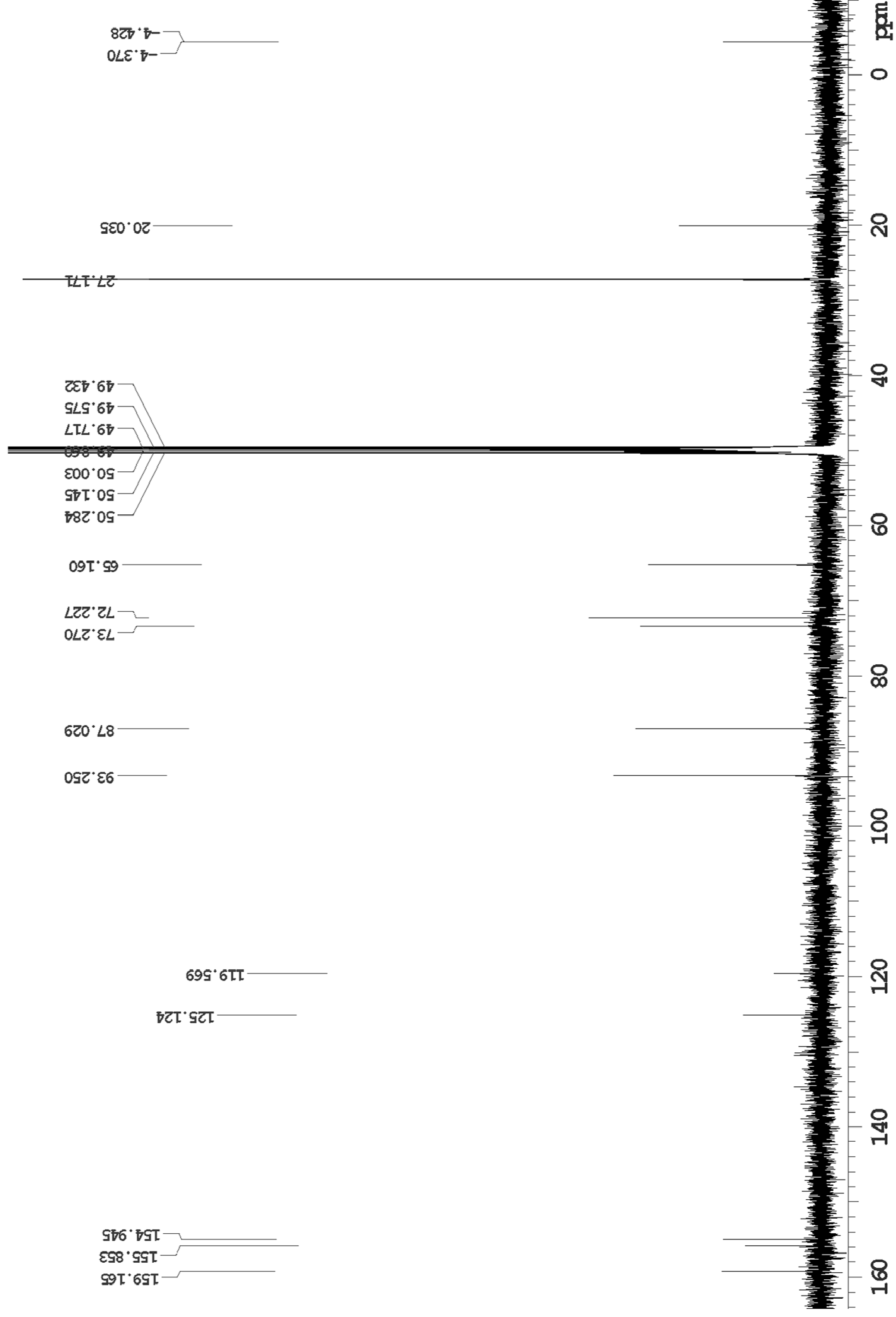

${ }^{13} \mathrm{C}\{1 \mathrm{H}\} \mathrm{NMR}\left(\mathrm{CD}_{3} \mathrm{OD}, 151 \mathrm{MHz}\right)$ of $\mathbf{1 0}$ 


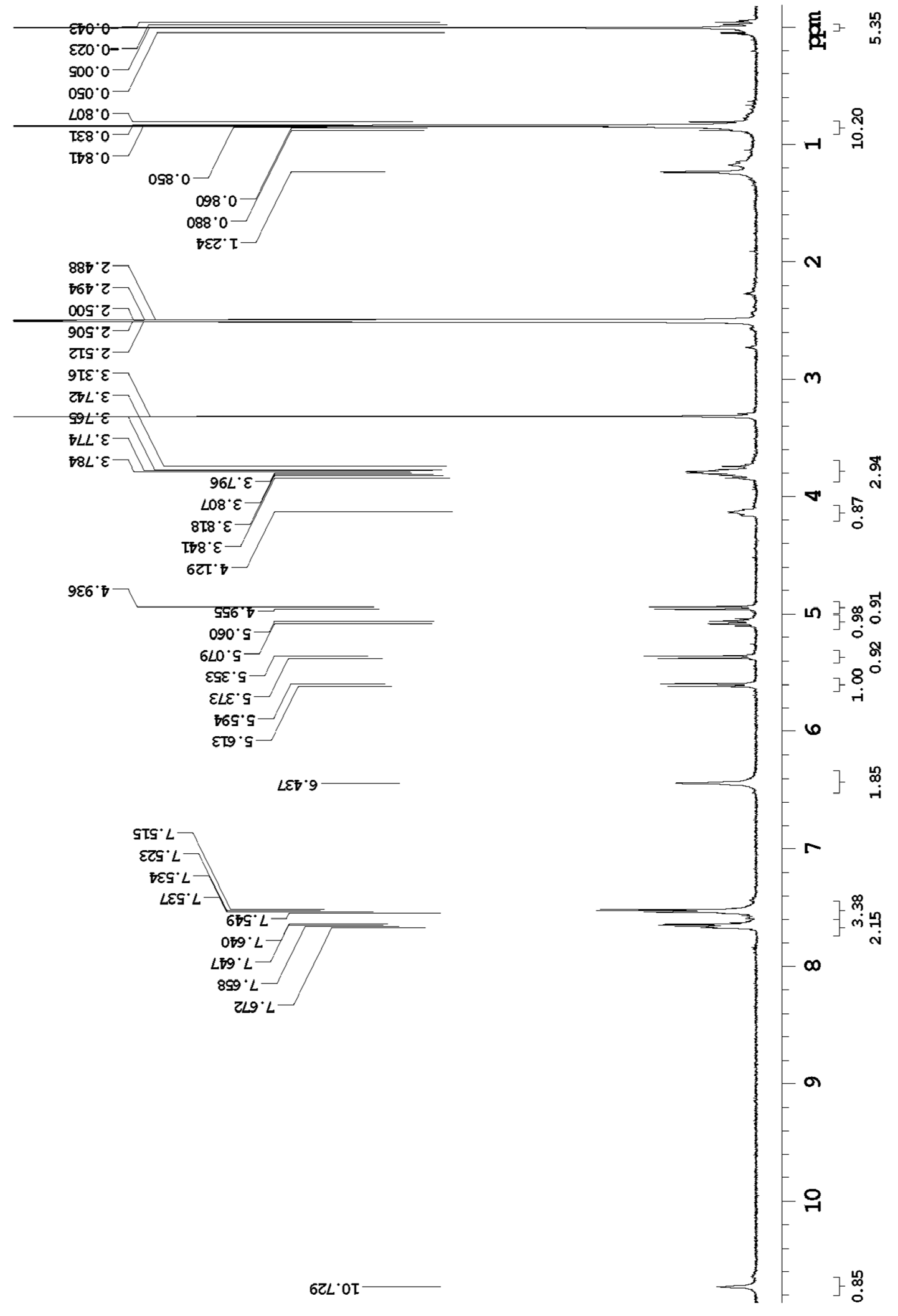

${ }^{1}$ H-NMR (dmso-d6, $600 \mathrm{MHz}$ ) of 11 


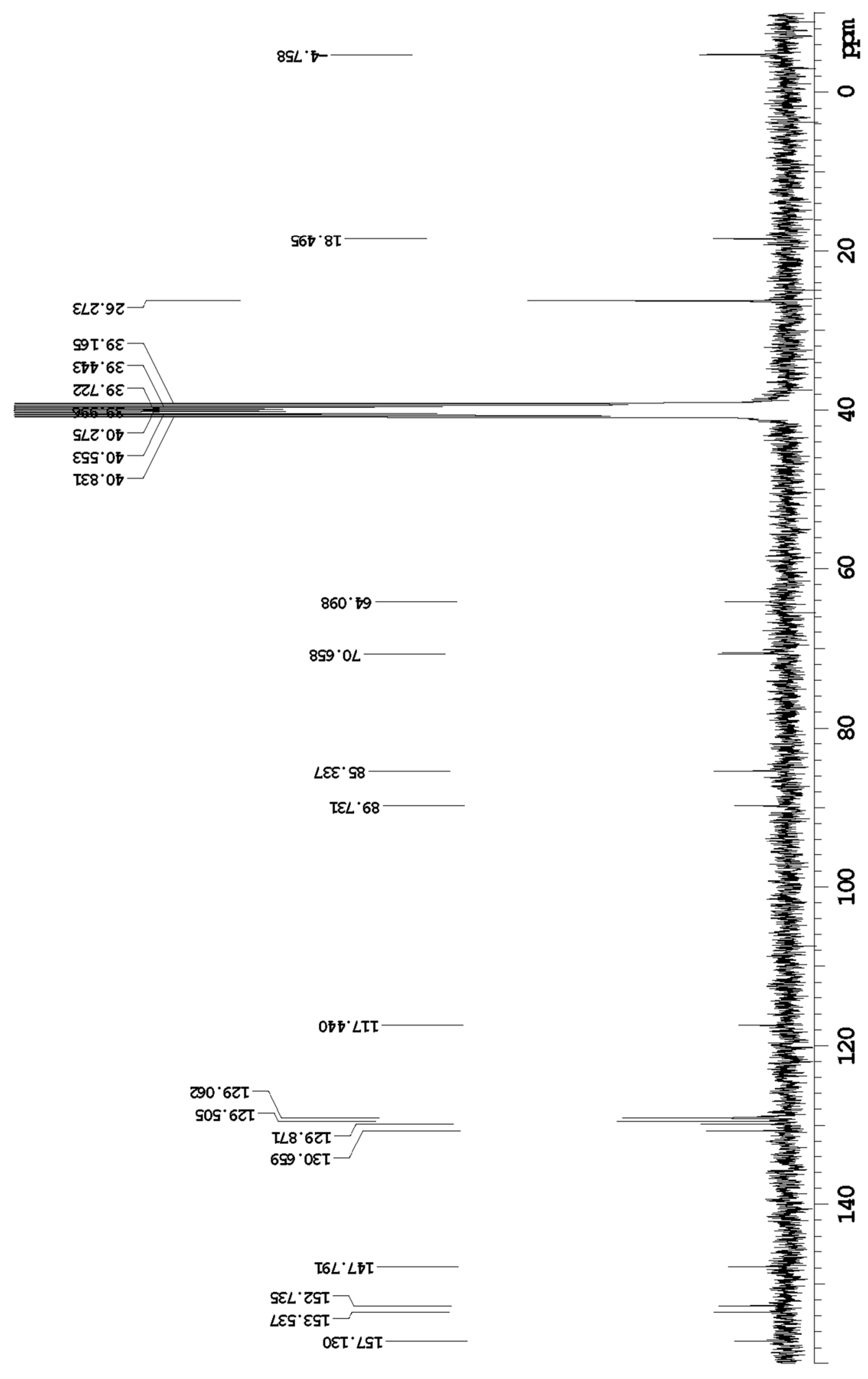

${ }^{13} \mathrm{C}\{1 \mathrm{H}\}$ NMR (dmso-d $\left.6,75 \mathrm{MHz}\right)$ of $\mathbf{1 1}$ 


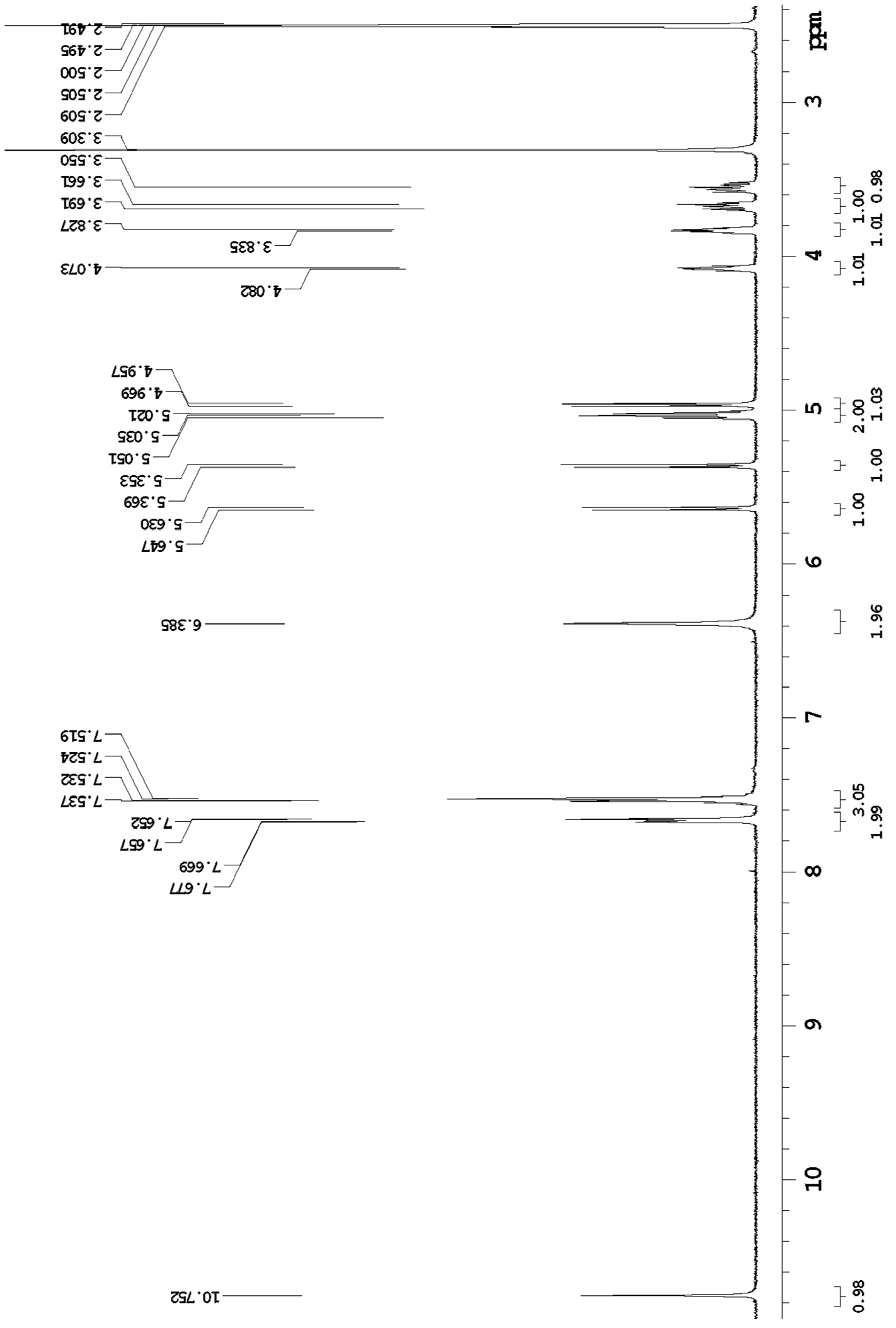

${ }^{1} \mathrm{H}-\mathrm{NMR}$ (dmso-d6, $400 \mathrm{MHz}$ ) of $\mathbf{1 2}$ 


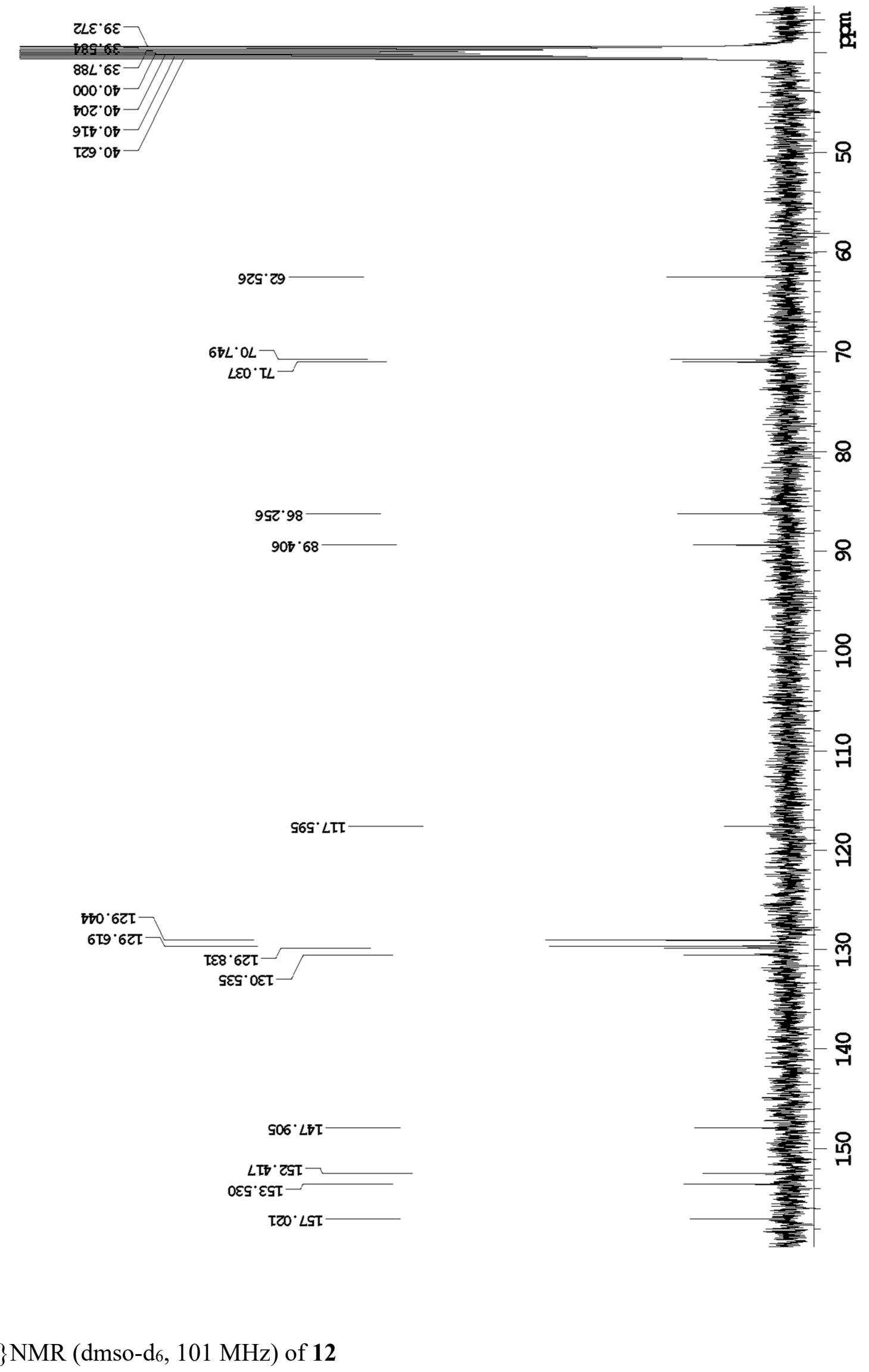

${ }^{13} \mathrm{C}\{1 \mathrm{H}\}$ NMR (dmso-d $6,101 \mathrm{MHz}$ ) of $\mathbf{1 2}$ 


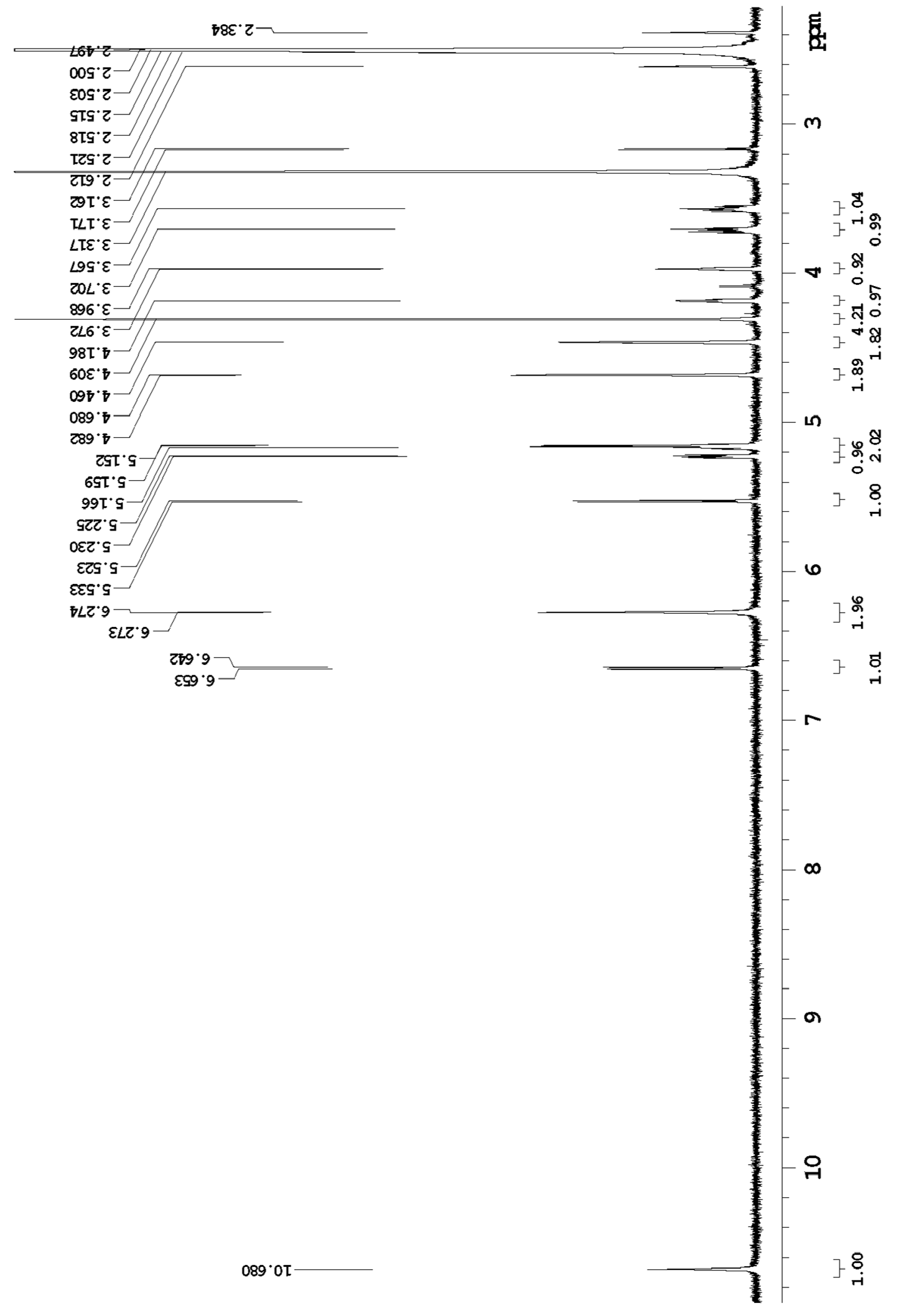

${ }^{1} \mathrm{H}-\mathrm{NMR}$ (dmso-d6, $600 \mathrm{MHz}$ ) of $\mathbf{1 3}$ 


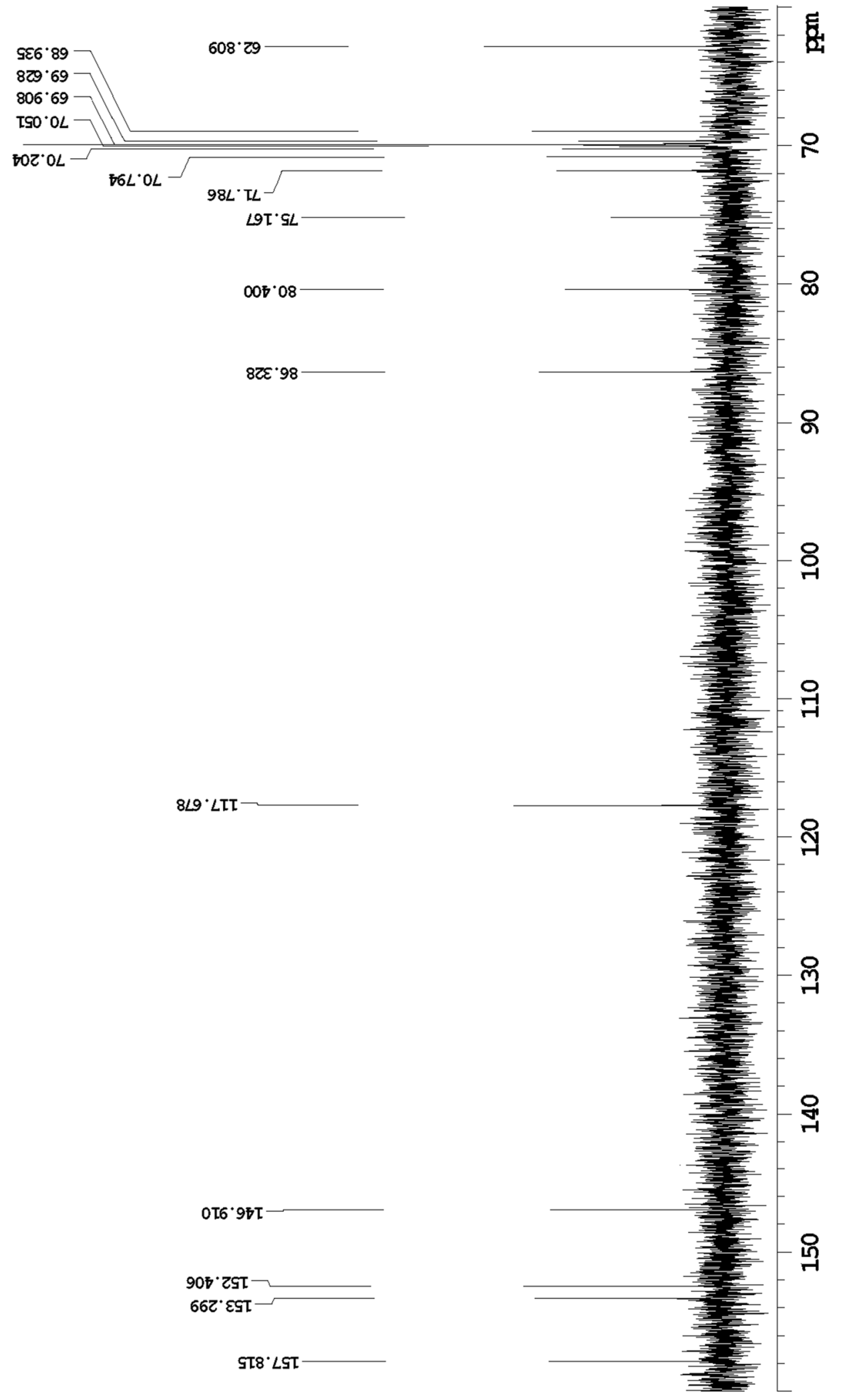

${ }^{13} \mathrm{C}\{1 \mathrm{H}\}$ NMR (dmso-d, $\left.151 \mathrm{MHz}\right)$ of $\mathbf{1 3}$ 


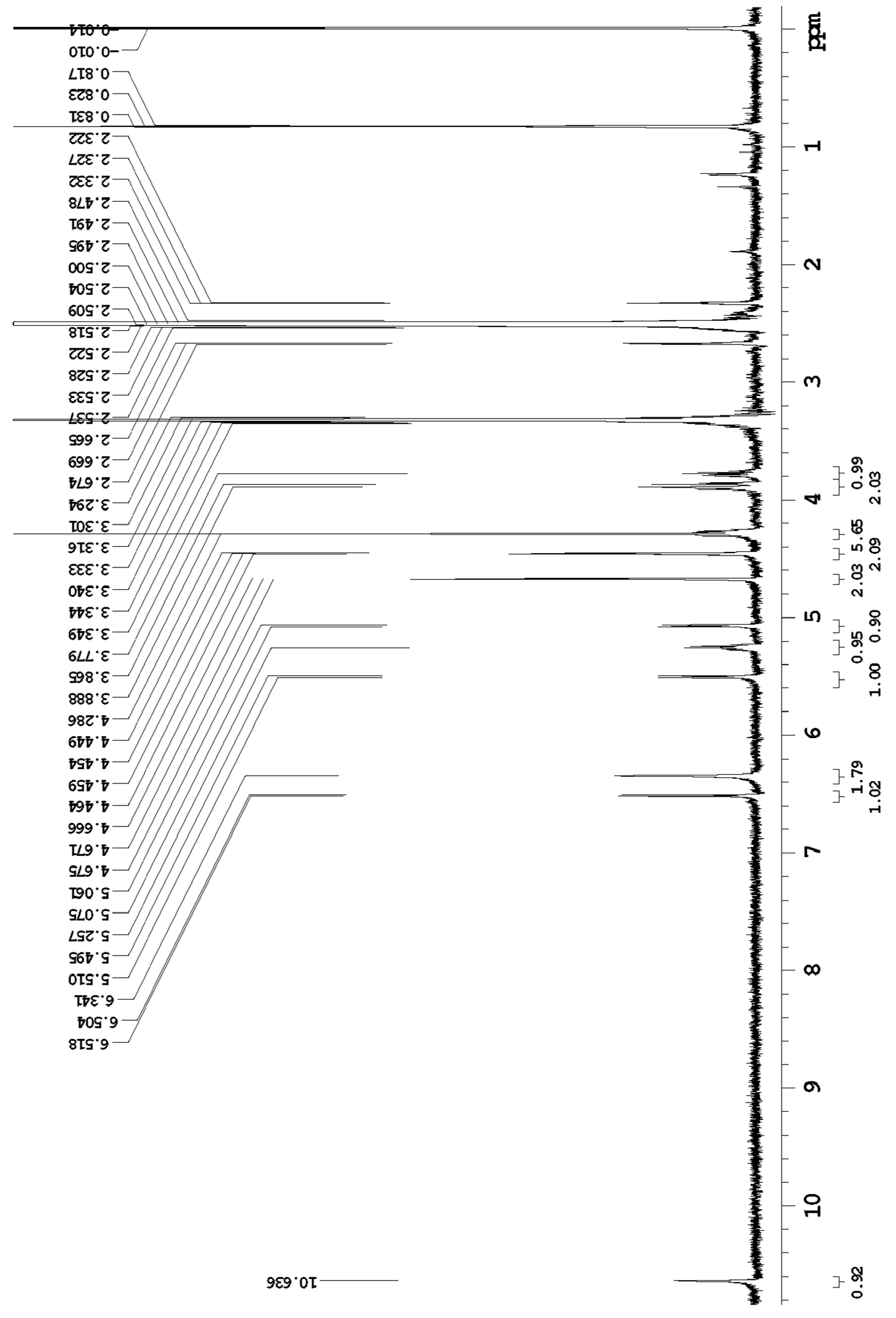

${ }^{1} \mathrm{H}-\mathrm{NMR}$ (dmso-d6, $400 \mathrm{MHz}$ ) of $\mathbf{1 4}$ 


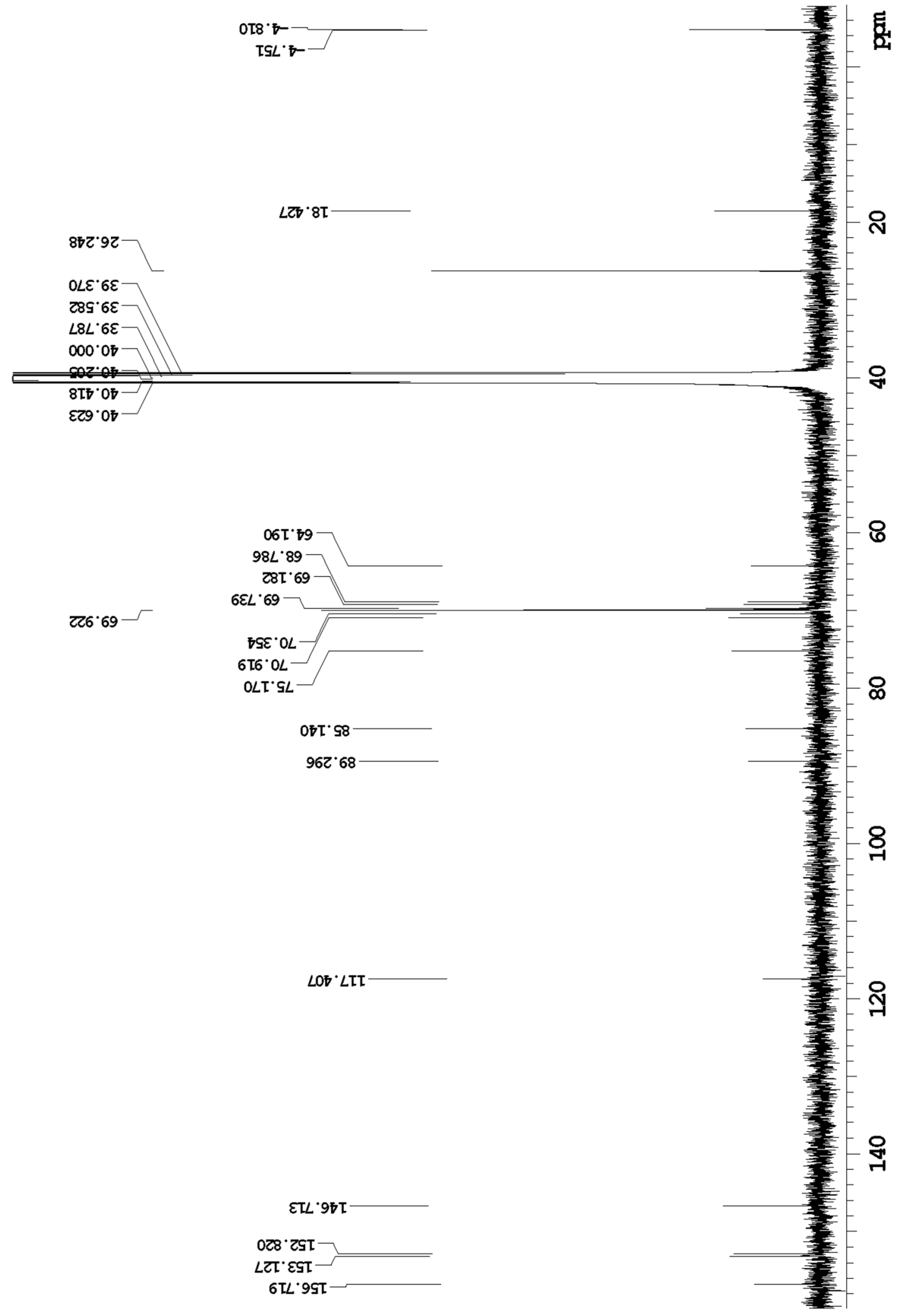

${ }^{13} \mathrm{C}\{1 \mathrm{H}\}$ NMR (dmso-d6, $\left.101 \mathrm{MHz}\right)$ of $\mathbf{1 4}$ 